Portland State University

PDXScholar

\title{
Hydrogeology of an alluvial aquifer in the Blue Lake area, east Multnomah County, Oregon
}

James Mitchell Wilkinson

Portland State University

Follow this and additional works at: https://pdxscholar.library.pdx.edu/open_access_etds

Part of the Geology Commons

Let us know how access to this document benefits you.

\section{Recommended Citation}

Wilkinson, James Mitchell, "Hydrogeology of an alluvial aquifer in the Blue Lake area, east Multnomah County, Oregon" (1991). Dissertations and Theses. Paper 4289.

https://doi.org/10.15760/etd.6172

This Thesis is brought to you for free and open access. It has been accepted for inclusion in Dissertations and Theses by an authorized administrator of PDXScholar. Please contact us if we can make this document more accessible: pdxscholar@pdx.edu. 
AN ABSTRACT OF THE THESIS OF James Mitchell Wilkinson for the degree of Master of Science in Geology presented August 9,1991 .

Title: Hydrogeology of an Alluvial Aquifer in the Blue Lake Area, East Multnomah County, Oregon.

APPROVED BY THE MEMBERS OF THE THESIS COMMITTEE:

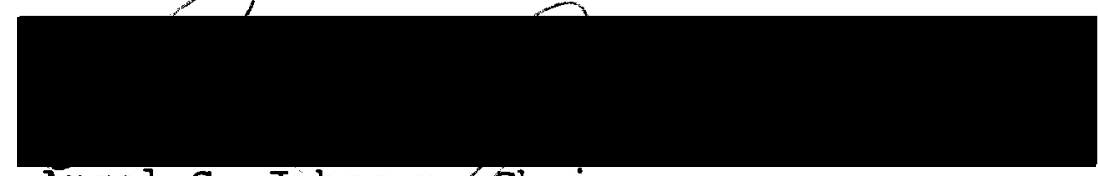

Ansel G. Johnson / Chair
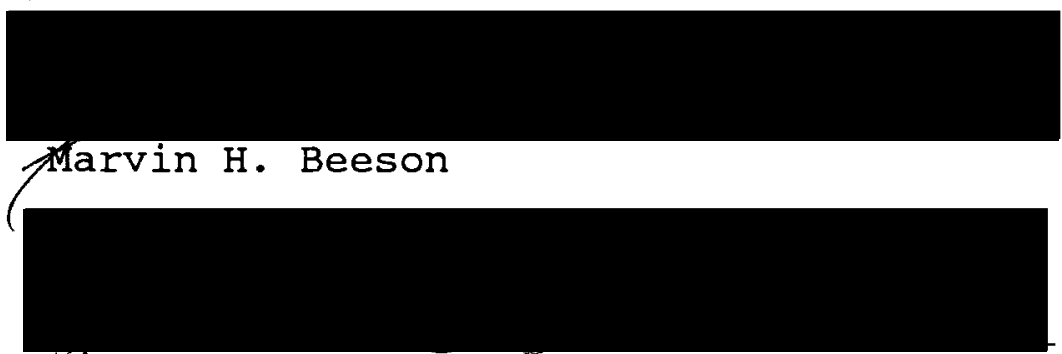

Richard E. Thoms

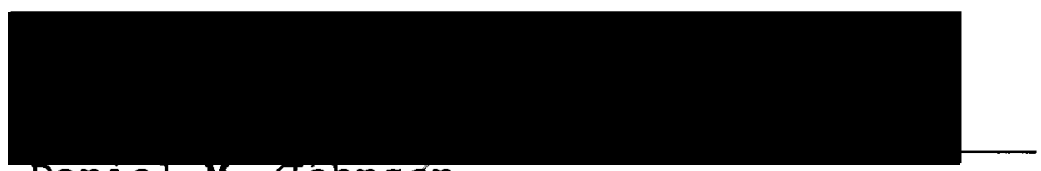

Daniel M. JJohnson

This thesis evaluates the hydraulic relationship between the Blue Lake gravel aquifer, the Columbia River, and Blue Lake. Hydrogeology, water levels, and stable isotopes were used to establish these hydraulic relationships.

The Blue Lake gravel aquifer consists of coarse channel deposits of the ancestral Columbia River. The sediments are 
predominantly gravel, cobbles, and boulders in a silty to sandy matrix. The clasts are basalt, with lesser amounts of andesite and quartzite. The transmissivity was estimated to be $20,490 \mathrm{~m}^{2} /$ day and the hydraulic conductivity was estimated to be $683 \mathrm{~m} /$ day. A deposit of gravel, cobbles, and boulders that is submerged along the south shore of the Columbia River is interpreted to be Blue Lake gravel aquifer sediments, suggesting a hydraulic connection at this location.

Stable isotopes of oxygen and hydrogen were used as natural tracers to determine if water was being contributed to the aquifer from the Columbia River and Blue Lake. There was a pronounced change in isotopic composition of water sampled during a pump test indicating a contribution of water from the river, estimated to be $72 \%$ after 22 days of pumping. A small change in isotopic composition occurred in a sample taken near the lake.

Analysis of water level data showed that water levels in the aquifer and those in the Columbia River are not independent of each other. These water levels correlate very well and the response to river stage within the aquifer diminishes with distance. The water levels in Blue Lake and the aquifer were found to be independent of each other.

A strong hydraulic connection exists between the columbia River and the Blue Lake gravel aquifer. The hydraulic connection of Blue Lake and the aquifer is weak and can only 
be observed under stressed conditions. 
HYDROGEOLOGY OF AN ALLUVIAL AQUIFER IN THE

BLUE LAKE AREA, EAST MULTNOMAH COUNTY, OREGON

by

JAMES MITCHELL WILKINSON

A thesis submitted in partial fufillment of the requirements for the degree of

\author{
MASTER OF SCIENCE \\ in \\ GEOLOGY
}

Portland State University

1991 
TO THE OFFICE OF GRADUATE STUDIES:

The members of the committee approve the thesis of James Mitchell Wilkinson presented August 9, 1991.

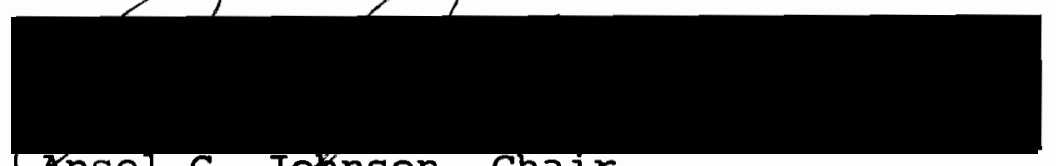

Ensel G. Johnson, Chair

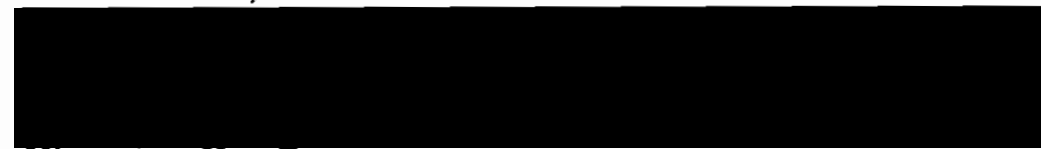

Marvin H. Beeson

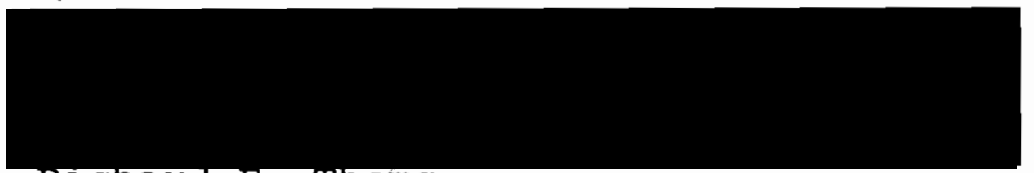

Richard E. Thoms
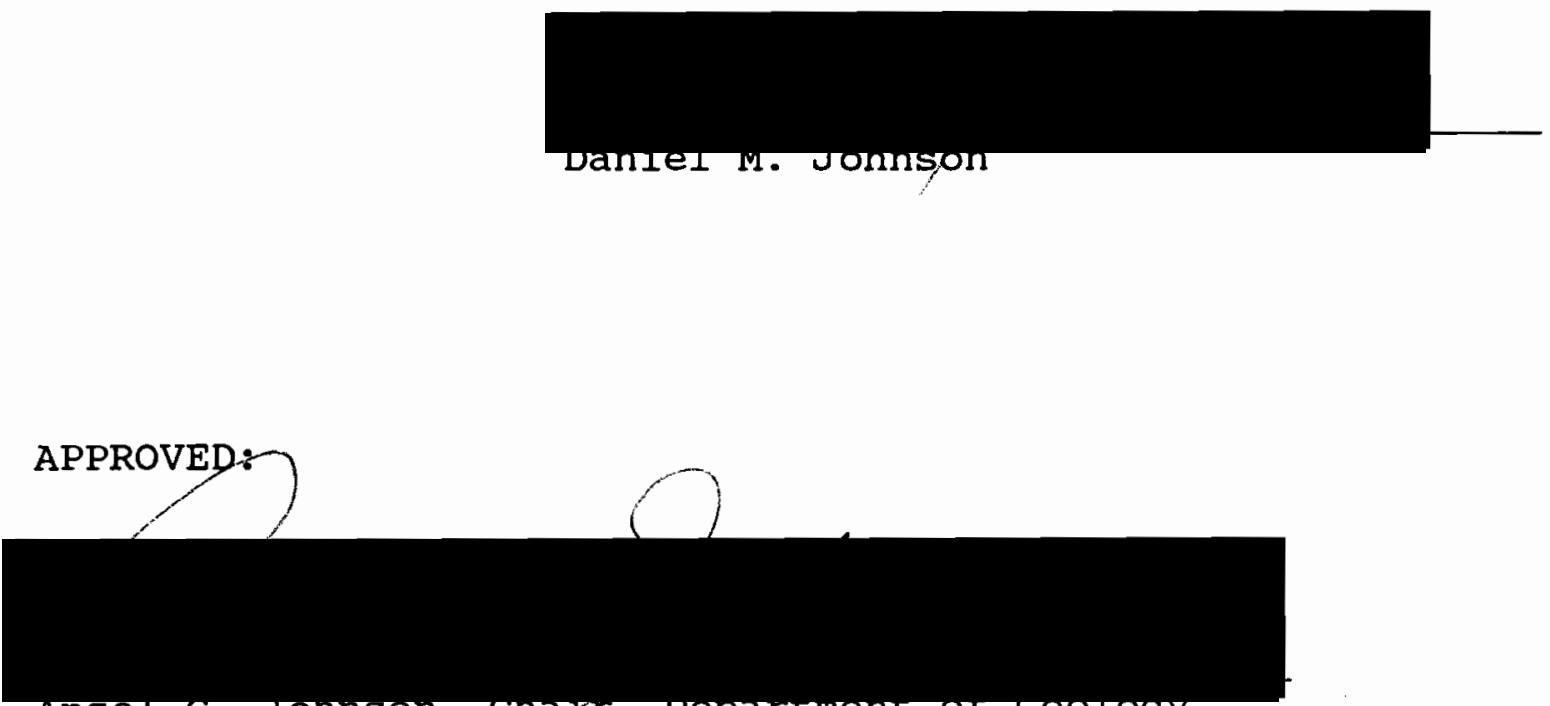

Ansel G. Jonnson, Cnapr, Department of Geology

C. William Savery, Interim Vice/Provost for Graduate studies and Research 


\section{ACKNOWLEDGEMENTS}

I would like to extend my sincere appreciation to my advisor Ansel Johnson. Without his guidance and support, I could not have completed my thesis. I would also like to thank my other committee members, Marvin Beeson and Richard Thoms, for their valuable comments and suggestions.

My particular thank you goes to the Portland office of the U.S.G.S. Water Resources Division for the use of their resources and equipment. William McFarland deserves a special thank you for the many hours of conversations we had, from the inception to the completion of this thesis. I would also like to thank Kathy McCarthy for providing me with information about stable isotopes.

There have been many others among the faculty, students, colleagues, and friends who have contributed to my thesis. I can not express my gratitude enough to the people associated with me through the U.S.G.S. and Portland state University, Geology Department. Through these two entities I have learned so many things.

Finally, I come to my wife, Yaeko, without whose love, support and patience, this thesis would have forever remained a dream. I dedicate this thesis to Yaeko. My accomplishment is hers as much as mine. 
TABLE OF CONTENTS

PAGE

ACKNOWLEDGEMENTS • . • . . . . . . . . . . . . . . . iii

LIST OF TABLES . . . . . . . . . . . . . . . . . . . . vi vi

IIST OF FIGURES . . . . . . . . . . . . . . . . . . vii

CHAPTER

I INTRODUCTION . . . . . . . . . . . . . . 1

Location and setting . . . . . . . . 1

Purpose and Scope . . . . . . . . . . 3

Previous Work . . . . . . . . . 4

II HYDROGEOLOGY . . . . . . . . . . . . 5

Methods of Investigation . . . . . . 5

Blue Lake Gravel Aquifer . . . . . . 9

Lithology and Extent

Hydraulic Characteristics

Adjacent Units . . . . . . . . 16

Recent Alluvium (Qal)

Troutdale Sandstone Aquifer (TSA)

Confining Unit (CU)

Sand and Gravel Aquifer (SGA)

Discussion . . . . . . . . . . . . 18

III STABLE ISOTOPE ANALYSIS . • . . . . . . 27

Methods of Investigation . . . . . . 27

Results . . . . . . . . . . . . 29

Discussion . . . . . . . . . . 29 
PAGE

IV WATER LEVEL ANALYSIS . • . • • • . • • . • . 38

Methods of Investigation . . . . . . 38 Results . . . . . . . . . . . . . 40 Discussion . . . . . . . . . . 40

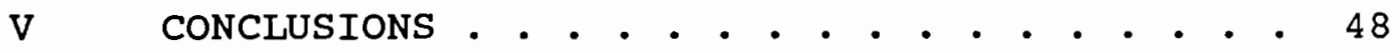

REFERENCES CITED • • • • • • • • • • • • • • • • • • . 50 APPENDICES

A WELL IDENTIFICATION CROSS REFERENCE • • • • • 53

B HYDROLOGIC AND METEOROLOGIC DATA . • . . . . . 55

C COMPUTER PROGRAMS . . . . . . . . . . . . . 75 


\section{LIST OF TABLES}

TABLE

PAGE

I Top and Bottom Elevations for the Blue Lake

$$
\text { Gravel Aquifer . • . . . . . . . . } 11
$$

II Drawdown Data for August 1990 Pump Test . . 12

III Calculated Values of Transmissivity and

Storage Coefficient . . . . . . . . 15

IV oxygen ${ }^{18}$ and Deuterium Values for Water

Samples collected in March and August

1990 (Relative to SMOW) . . . . . . 30 


\section{LIST OF FIGURES}

1. Location of the Study Area . . . . . . . . . 2

2. Well Locations and Identification . • . . . . 6

3. Example of Geologic and Drillers

Lithologies • • • • • . • • • • . 7

4. Time vs. Drawdown Plot of the August 1990

Pump Test Data for Well 6 . . . . . . 13

5. Time vs. Drawdown Plot of the August 1990

Pump Test Data for Well 9 . . . . . . 14

6. Distance vs. Drawdown Plot of the August

1990 Pump Test Data . . . . . . . . 15

7. Contour Map of the Top of the Blue Lake

Gravel Aquifer, Modified from

Hartford and McFarland (1989) . . . . . 21

8. Contour Map of the Bottom of the Blue Lake

Gravel Aquifer, Modified from

Hartford and McFarland (1989) . . . . . 22

9. North-South Hydrogeologic section

Through the Blue Lake Area . . . . . . 23

10. Drawdown Data for well 6 with Theis Type

Curve • • • • • • • • • • • • • • • . 24

11. Drawdown Data for well 9 with Theis Type 
12. Initial composition of oxygen ${ }^{18}$ and Deuterium Before Pumping . . . . . . 31

13. Initial vs. Late Compositions of Oxygen ${ }^{18}$ and Deuterium for selected Locations . . 32 14. Oxygen ${ }^{18}$ and Deuterium Compositions With Respect to Time for Well 19 . . . 35 15. Oxygen ${ }^{18}$ vs. Time, Well 19 . . . . . . . 36 16. Deuterium vs. Time, Well 19 . . . . . . 36

17. Columbia River Stage, February, 1991 . . . . 42

18. Water Levels in Well 6, February, 1991 . . . 42

19. Water Levels in Well 4, February, 1991 . . . 43

20. Barometric Pressure, February, 1991 . . . . 43

21. Precipitation, February, 1991 . . . . . . 44

22. Correlogram for Water levels

in Well 6 and the Columbia River . . . 44 23. Correlogram for Water Levels

in Well 4 and the Columbia River . . . 46 24. Correlogram for Water Levels

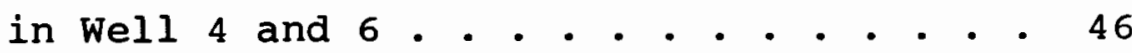


CHAPTER I

INTRODUCTION

LOCATION AND SETTING

The Blue Lake area is located along the southern shore of the Columbia River in east Multnomah County, Oregon (Figure 1). The study area extends from Fairview Lake to the Columbia River and from Taggart Bluff to Campbell Road. These boundaries encompass the known extent of the Blue Lake gravel aquifer (Hartford and McFarland, 1989).

The Blue Lake area is a small part of a much larger area, the Portland Basin, which the Columbia River flows through. The Portland Basin is a northwest trending sediment filled structural depression. The primary sedimentary units are the Sandy River Mudstone, Troutdale Formation, and catastrophic flood deposits. Several other local deposits occur within the Portland Basin to a lesser extent.

The City of Portland operates a well field which serves as a backup municipal water supply. The eastern portion of the well field extends to the Blue Lake area (see Figure 1). A park in the Blue Lake area is operated by Multnomah County and provides picnic and water activities to the public. In addition, there are several residences along the shores of Blue Lake and Fairview Lake. To the east and south of the 


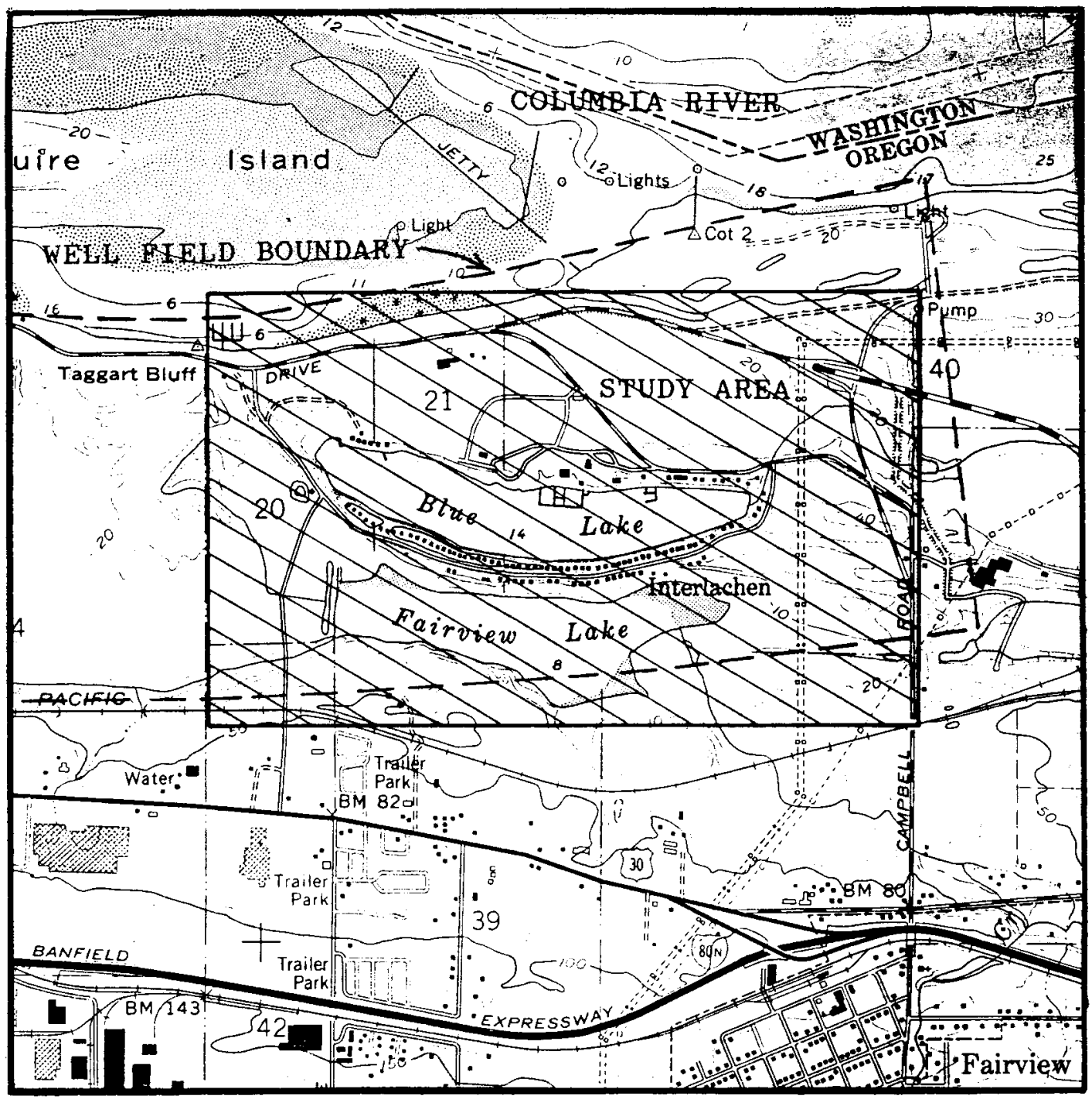

1

Figure 1. Location of the study area. 
study area are some industrial districts. Groundwater south of the study area has been found to contain contaminants and is a source of concern to the city of Portland and other local groundwater users (Malin, 1989; Leighton, 1990; Lindberg, written communication). Land to the west is primarily farmland.

The climate of the study area is generally mild most of the year but can be unseasonably cold in winter due to the proximity of the mouth of the Columbia Gorge. The area receives about 117 to 127 centimeters of rain annually (D. Snyder, written communication) and is moderately drained with some ponding occurring in low lying areas.

\section{PURPOSE AND SCOPE}

The Blue Lake gravel aquifer is very productive as a groundwater source. There is the possibility that groundwater withdrawal and contamination in the area could adversely affect the quality and/or quantity of the groundwater. It is important to know the source of the groundwater and the general hydrogeologic characteristics of the aquifer. Successful use, future development, and protection of the aquifer is dependent upon knowledge and understanding of the hydrogeology and hydraulic characteristics of the aquifer.

The proximity of the Columbia River and Blue Lake suggest that there may be a relationship between the aquifer 
and these water bodies. The goal of this study was to evaluate and establish the relationships of the river and lake to the aquifer. This information will help to provide a better understanding of the hydrogeology of the Blue Lake gravel aquifer.

\section{PREVIOUS WORK}

There are several reports which describe the geology and hydrogeology in the Portland vicinity. of these, there are two published reports which involve work in the Blue Lake area. Hoffstetter (1984) briefly describes the Blue Lake aquifer within his report of the geology of the Portland well field. A more detailed description is contained in a report by Hartford and McFarland (1989). In addition to these reports, there are some unpublished reports of limited distribution done by the city of Portland and by various consulting firms (eg. Landau Associates, Dames and Moore).

Other published reports for the vicinity include those by Griffin and others (1956), Hogenson and Foxworthy (1965), Swanson and others (in press), and Trimble (1963). These reports contain geologic and hydrogeologic descriptions covering the broad region, but not necessarily the Blue Lake gravel aquifer. 
CHAPTER II

\section{HYDROGEOLOGY}

\section{METHODS OF INVESTIGATION}

The Blue Lake gravel aquifer was evaluated using a combination of methods. Initially, literature relevant to the area and subject were reviewed and compiled. Geologic and drillers well logs supplied by the U.S.G.S. were used to provide additional information at well locations in the Blue Lake area. Figure 2 shows the distribution and location of these wells. A well ID cross reference can be found in appendix A. Lithology from the geologic and drillers logs was coded and graphically drafted on a polyester film overlay. Figure 3 shows an example of this procedure. At locations which have both geologic and drillers logs, the lithologic descriptions were compared to examine differences in interpretation. This provided a method of control for interpreting those drillers logs which had no corresponding geologic logs. The lithologic description of the aquifer given in Hartford and McFarland (1989) was compared to the lithology on the graphic plot to determine the interval which represents the aquifer. The elevations of the top and bottom of the aquifer were picked from the graphic plot. An unpublished contour map of the bottom of Blue Lake 


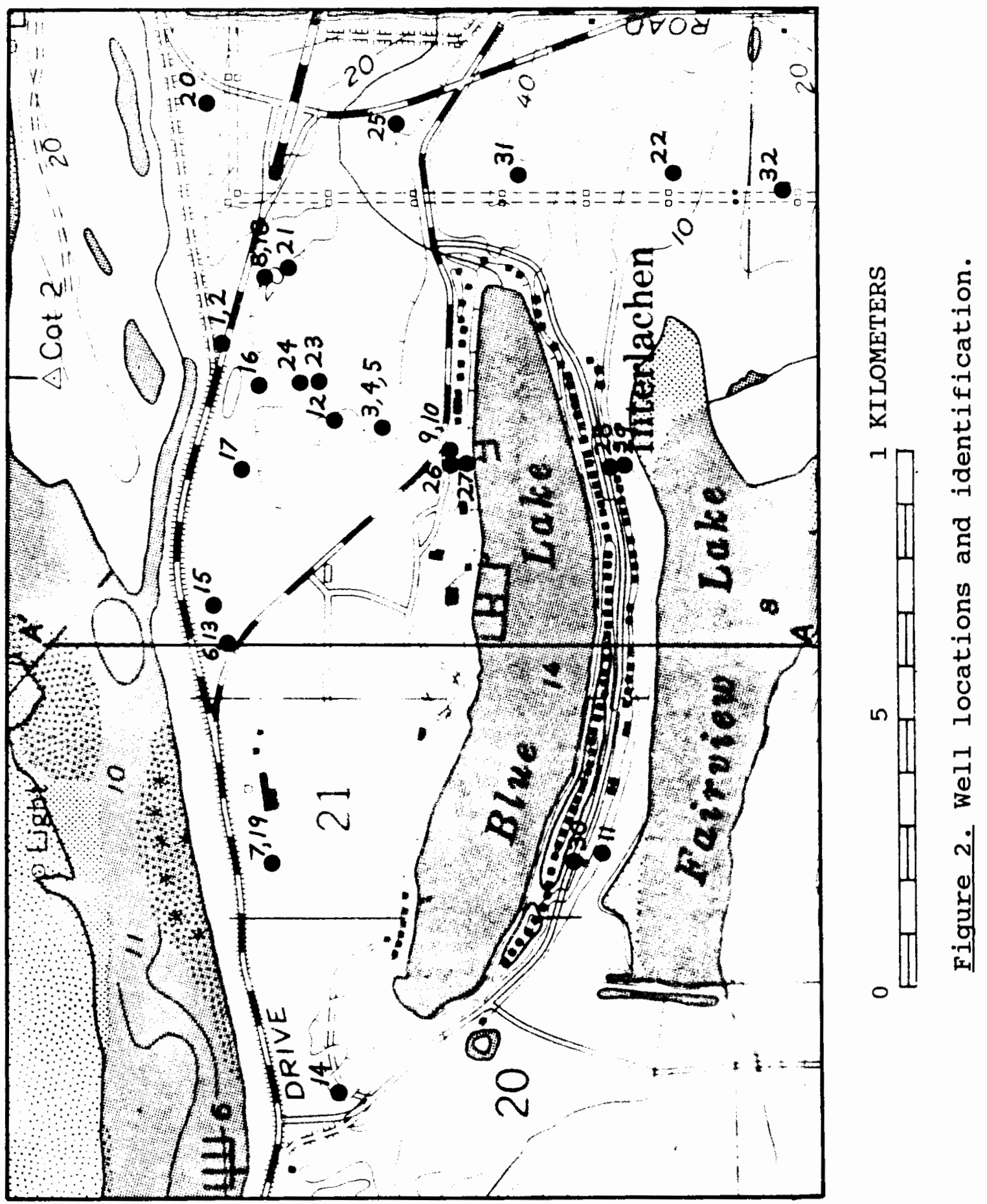




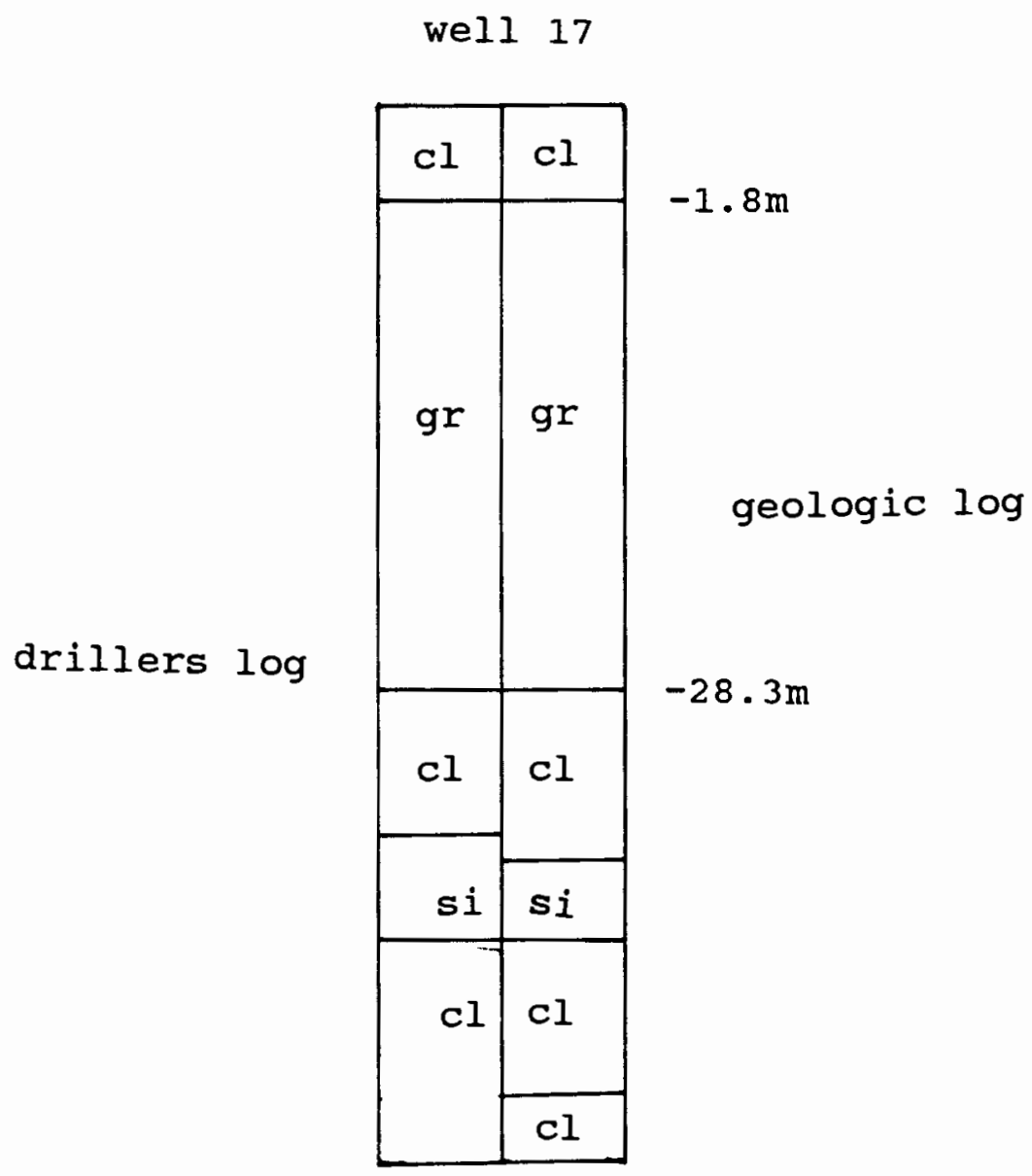

\section{EXPLANATION}

$$
\begin{array}{ll}
\text { cl } & \text { clay } \\
\text { gr } & \begin{array}{l}
\text { gravel } \\
\text { silt }
\end{array} \\
& \\
& 1 \mathrm{~cm}=6 \mathrm{~m}
\end{array}
$$

Figure 3. Example of geologic and drillers lithologies. 
(McFarland, written communication) provided additional control for estimating the altitude of the top of the aquifer below Blue Lake. These data were combined with those of Hartford and McFarland (1989) and contoured to create modified maps of the top and bottom of the aquifer.

The City of Portland provided discharge and drawdown data for a pump test at well 19 in August 1990. These data were used to calculate the hydraulic characteristics of the aquifer. Distance versus drawdown (see Figure 6) and time versus drawdown (see Figure 4,5 ) were plotted and the resulting parameters were used to calculate transmissivity, storage coefficient, and hydraulic conductivity. The following relationships from Heath (1982) were used for distance versus drawdown:

$$
\begin{aligned}
& \mathrm{T}=2.3 \mathrm{Q} /(2 \pi \mathrm{s}) \\
& \mathrm{S}=2.25 \mathrm{Tt} / \mathrm{r}_{0}{ }^{2}
\end{aligned}
$$

where $T$ is transmissivity in square meters per day, $Q$ is discharge in cubic meters per day, $s$ is drawdown over one $\log$ cycle in meters, $t$ is time of measurement in days since pumping started, and $r_{0}$ is the distance in meters ( $x$ intercept at drawdown $=0$ ). For time versus drawdown, the following relationships were used from Heath (1982):

$$
\begin{aligned}
& \mathrm{T}=2.3 \mathrm{Q} /(4 \pi \mathrm{s}) \\
& \mathrm{S}=2.25 \mathrm{~T} \mathrm{t}_{0} / \mathrm{r}^{2}
\end{aligned}
$$

where $t_{0}$ is $x$ intercept at drawdown $=0$ in days and $r$ is the distance from the pumping well to the observation well in 
meters. Hydraulic conductivity is calculated using

$$
\mathrm{K}=\mathrm{T} / \mathrm{b}
$$

where $\mathrm{K}$ is the hydraulic conductivity in meters per day and b is the thickness of the aquifer in meters (Heath, 1982). Elevations above or below sea level are with respect to the National Geodetic Vertical Datum of 1929.

\section{BLUE LAKE GRAVEL AQUIFER}

\section{Lithology and Extent}

Lithologic data and descriptions recorded on drillers and geologic well logs provided data about the Blue Lake gravel aquifer sediments. Data from these well logs indicate that the sediments consist of $65 \%$ to $90 \%$ gravel to cobble size clasts with some boulders in a matrix of clayey to sandy silt based on the size classification given in Fetter (1988). The concentration of gravel to cobble size clasts is predominantly $75 \%$ to $85 \%$ throughout the sediments. Although the clast size varies, most are from fine gravel ( 6 $\mathrm{mm}$ ) to small cobble $(100 \mathrm{~mm})$ size with cobbles up to $152 \mathrm{~mm}$ and boulders up to $355 \mathrm{~mm}$ reported.

Data from geologic logs indicate that the composition of the clasts is $60 \%$ to $90 \%$ basalt, with up to $30 \%$ andesite, and up to $30 \%$ quartzite. There are also minor amounts of other metamorphic rocks and occasional pieces of sandstone reported in the geologic logs. The average composition is $75 \%$ to $85 \%$ basalt, $15 \%$ to $20 \%$ andesite, and $10 \%$ quartzite. 
The matrix varies from clayey silt to sand. Most descriptions are sandy silt to silty sand with some lesser amounts of coarse sand. Thin lenses of clay are reported in some of the wells at varying depths. There is no evidence of cementing in the aquifer.

The sediments of the aquifer are present at many well locations within the Blue Lake area. The westernmost occurrence of Blue Lake gravel sediments is at well 14 (see Figure 2 for location). The easternmost occurrence is at wells 20 and 25, and the southernmost occurrence is at well 27. All wells located within the boundary delineated by wells $14,20,25$ and 27 penetrate the aquifer sediments. Drillers and geologic well logs for wells farther east and west were examined and no trace of the aquifer sediments was found. There is a submerged deposit of gravel, cobbles, and boulders along the south shore of the Columbia River just east of Taggart Bluff which is the only outcrop of aquifer sediments observed.

Geologic logs were used to pick the top and bottom extent of the aquifer based on one or more changes in sediment characteristics. These characteristics are cementation, size distribution, and lithology. Table I summarizes the results.

\section{Hydraulic Characteristics}

In August 1990, the City of Portland conducted a pump test at well 19. The screened interval for well 19 is 
TABLE I

TOP AND BOTTOM ELEVATIONS FOR THE BLUE LAKE GRAVEL AQUIFER

\begin{tabular}{|c|c|c|}
\hline WELL & ELEVATION OF & AQUIFER (METERS) \\
\hline ID & TOP & BOTTOM \\
\hline 1 & $-\overline{3.0}$ & -70.7 \\
\hline 2 & -3.0 & -70.7 \\
\hline 3 & 0.9 & -32.0 \\
\hline 4 & 0.9 & -32.0 \\
\hline 5 & 0.9 & -32.0 \\
\hline 6 & 1.0 & -52.1 \\
\hline 7 & 1.8 & -28.3 \\
\hline 8 & -2.4 & -69.5 \\
\hline 9 & 6.7 & -36.0 \\
\hline 10 & 6.7 & -36.0 \\
\hline 12 & -0.6 & -31.4 \\
\hline 13 & 1.0 & -52.1 \\
\hline 14 & 3.0 & -16.5 \\
\hline 15 & -0.9 & - \\
\hline 16 & -0.3 & - \\
\hline 17 & 0.0 & -50.9 \\
\hline 18 & -1.5 & - \\
\hline 19 & -0.6 & -29.3 \\
\hline 20 & -19.5 & - \\
\hline 21 & 0.0 & - \\
\hline 23 & -0.9 & - \\
\hline 24 & -0.9 & -36.3 \\
\hline 25 & 0.3 & - \\
\hline 26 & 3.4 & - \\
\hline 27 & 3.4 & - \\
\hline
\end{tabular}

exclusively within the Blue Lake gravel aquifer. Well 19 was pumped at a rate of $37,900 \mathrm{~m}^{3} /$ day for 22 days (August 7 - 29). Water levels at two locations, wells 6 and 9 (see Figure 2), were monitored by the city of Portland during the pump test. Pumping was halted on August 18 for a day due to technical problems. The data from the pump test were selected from the period of pumping prior to August 18 and are shown in Table II. Wells 6 and 9 are approximately 427 
TABLE II

DRAWDOWN DATA FOR AUGUST 1990 PUMP TEST

TIME SINCE PUMPING

STARTED (DAYS)

0.68

1.02

1.70

2.05

2.67

3.75

4.74

5.74

6.87

7.73
DRAWDOWN (METERS) Well 6

0.49

0.55

0.61

0.64

0.70

0.73

0.79

0.94

1.01

0.98
Well 9

0.27

0.34

0.43

0.46

0.52

0.55

0.61

0.73

0.82

0.85

meters and 844 meters away from well 19, respectively.

The data in table II are shown in Figures 4 and 5 as plots of time versus drawdown. Logarithmic best fit lines are projected back to the point of no drawdown and the corresponding times were used for calculating transmissivities and storage coefficients. Figure 6 shows the data plotted as distance versus drawdown for the successive measurement times. Logarithmic best fit lines are projected through the data out to the point of no drawdown and the corresponding distances were used for transmissivity and storage coefficient calculations. Calculations were made using equations 1 and 2 for distance versus drawdown and equations 3 and 4 for time versus drawdown. These calculated values are summarized in Table III. 


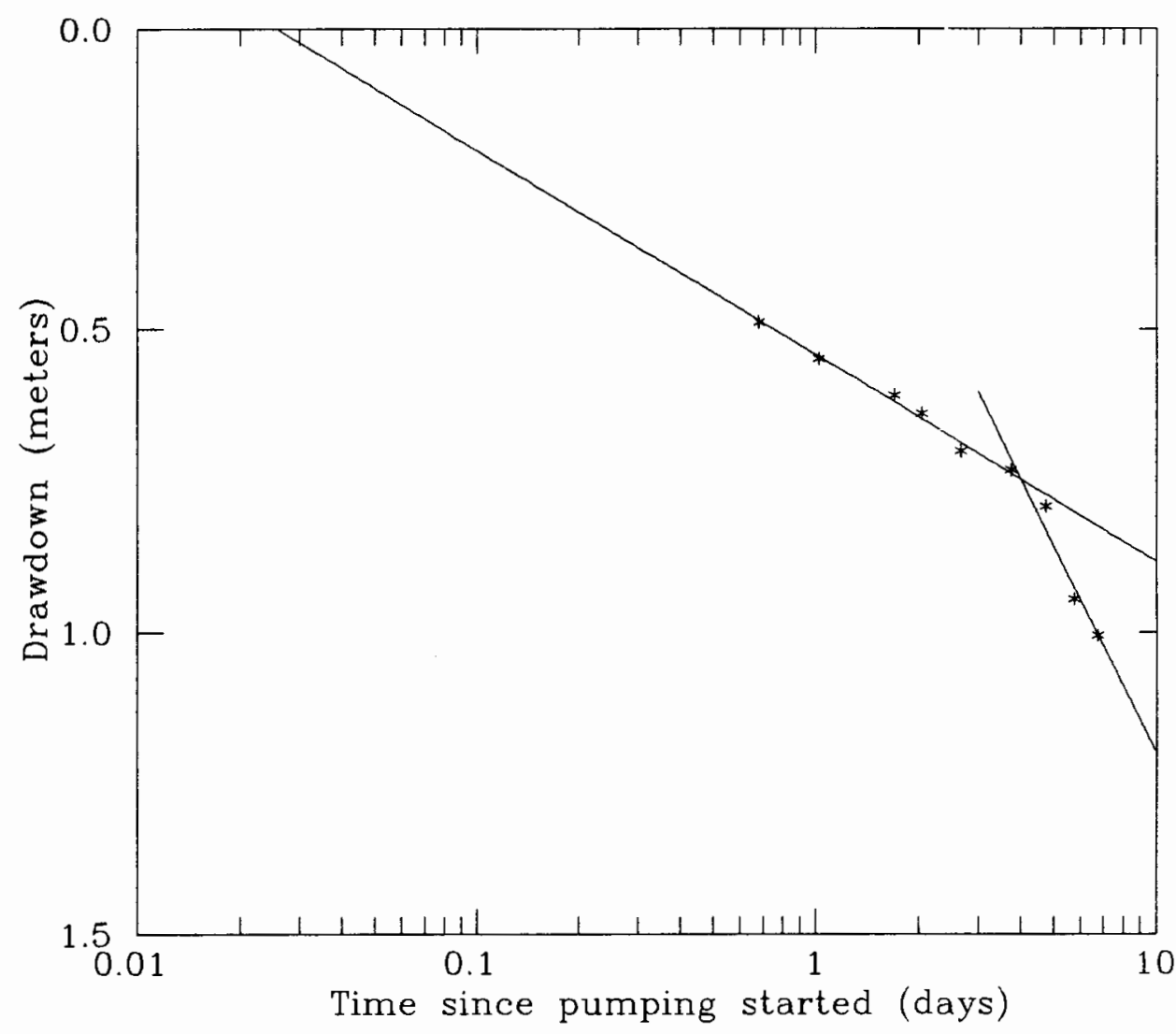

Figure 4. Time vs. drawdown plot of the August 1990 pump test data for well 6 . 


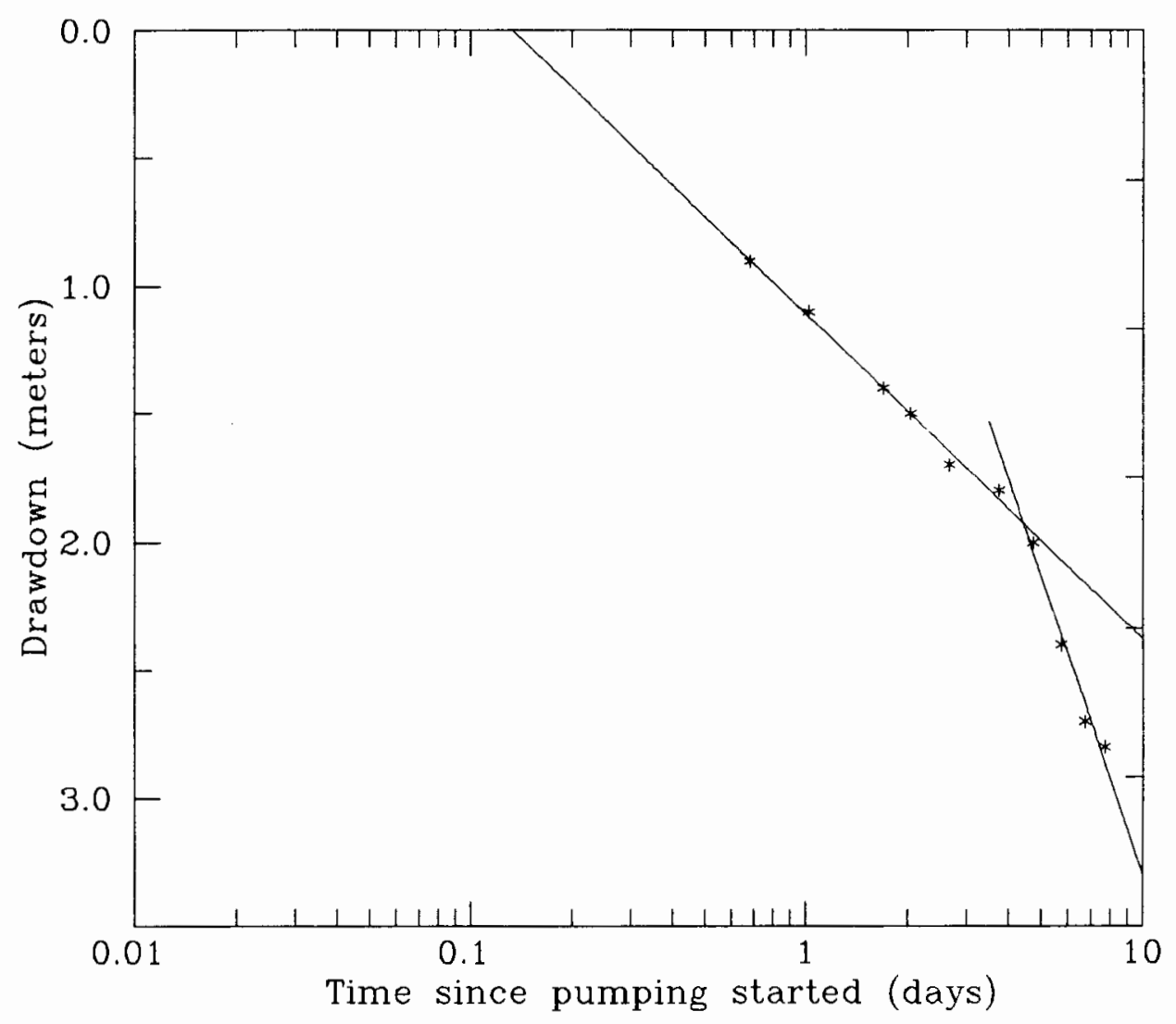

Figure 5. Time vs. drawdown plot of the August 1990 pump test data for well 9 . 


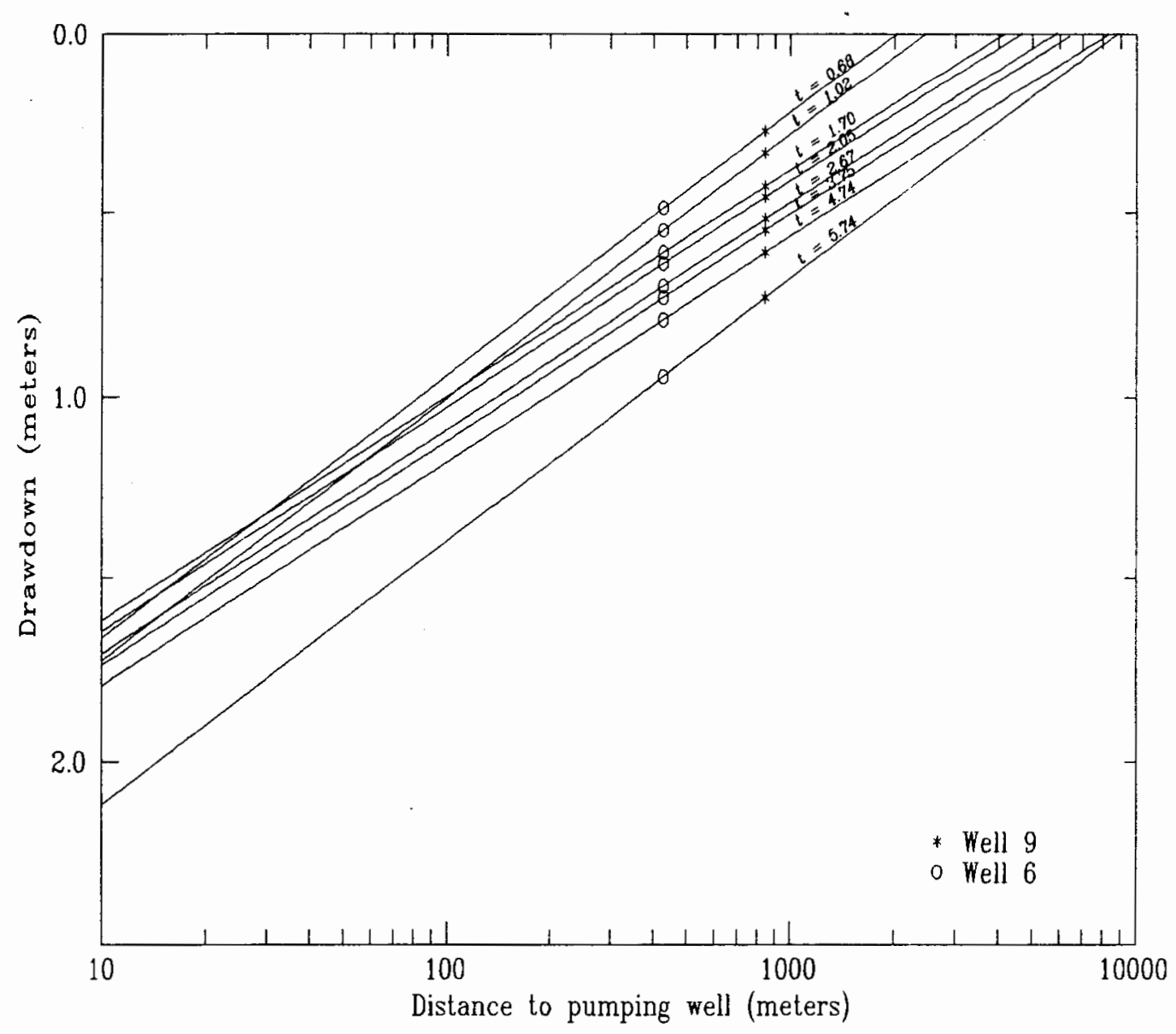

Figure 6. Distance vs. drawdown plot of the August 1990 pump test data.

TABLE III

CALCULATED VALUES OF TRANSMISSIVITY AND STORAGE COEFFICIENT

TRANSMISSIVITY

$\left(\mathrm{M}^{2} /\right.$ day $)$

20,410

17,880

19,270

19,270

22,480

22,480

21,630

22,480

22,480

19,270
STORAGE

COEFFICIENT

0.006

0.007

0.007

0.007

0.005

0.005

0.005

0.004

0.004

0.003
COMMENTS

well 6 (figure 4)

well 9 (figure 5)

$t=0.68$ (figure 6)

$t=1.02$ (figure 6)

$t=1.70$ (figure 6)

$t=2.05$ (figure 6)

$t=2.67$ (figure 6)

$t=3.75$ (figure 6)

$t=4.74$ (figure 6)

$t=5.74$ (figure 6 ) 
Figures 4 and 5 show a break in slope at about 4 days. this change in hydraulic conditions represents a known bias and therefore values of transmissivity calculated from this point and later were not used for the average. The remainder of the values were used to calculate the average transmissivity. An average value of $20,490 \mathrm{~m}^{2} /$ day for transmissivity was used to calculate hydraulic conductivity. Based on a thickness of 30 meters at well 19, a hydraulic conductivity of $683 \mathrm{~m} /$ day was calculated. Assuming an average thickness of 38 meters within the aquifer, the hydraulic conductivity is $560 \mathrm{~m} /$ day.

\section{ADJACENT UNITS}

Recent Alluvium (Oal)

These sediments include overbank deposits and current channel deposits of the Columbia River. The overbank deposits are part of the Columbia River flood plain and are up to 10 meters thick in the study area. The lithology of the overbank deposits is described by Hartford and McFarland (1989) as silty clay to sandy silt which is unsaturated. The channel deposits are described by Hoffstetter (1981) as the Columbia River Sands Formation. These deposits are medium sands of quartz and basalt composition with interbedded thin beds of gravel, silt, and clay (Hoffstetter, 1981). The unit is up to 91 meters thick and overlies the Blue Lake gravel aquifer in well 20 (see figure 2) 
(Hoffstetter, 1981).

Troutdale Sandstone Aquifer (TSA)

The Troutdale sandstone aquifer is a coarse vitric sandstone with lenses and beds of conglomerate, sand, and silt (Swanson and others, in press). In the Blue Lake area, this unit crops out and forms a ridge between Blue Lake and Fairview Lake (see Figure 9). It has a dip of 12 to 14 degrees to the south (Hartford and McFarland, 1989) and is interpreted by Swanson (1986) as a homoclinal feature. It consists of moderate to well sorted, angular to sub-rounded, indurated basaltic glass (Hartford and McFarland, 1989). Wells completed in this unit have been tested at rates up to $9.5 \mathrm{~m}^{3} / \mathrm{min}$. (Swanson and others, in press).

\section{Confining unit (CU)}

The confining unit is described as confining unit 2 by Hartford and McFarland (1989) and Swanson and others (in press). It underlies the Troutdale sandstone aquifer and is encountered at depth in some of the wells in the Blue Lake area. Geologic logs for wells 14 and 19 indicate that it is composed of clay with silt and sand lenses and is described by willis (1978) as a leaky confining layer. These sediments are interpreted to be lacustrine by Trimble (1963). 
Sand and Gravel Aquifer (SGA)

The sand and gravel aquifer is the lowermost unit encountered in the Blue Lake area (see Figure 9). Data from well logs in the Blue lake area indicate that this unit is predominantly fine sand. It is described by Swanson and others (in press) as composed of silty sand, clay, sand, and sandy gravel. Hartford and McFarland (1989) describe the upper unit of the sand and gravel aquifer as being partially eroded in the Blue Lake area, exposing a finer grained facies. Swanson and others (in press) reports that this aquifer is very productive and has been tested at rates up to $11.4 \mathrm{~m}^{3} / \mathrm{min}$.

\section{DISCUSSION}

A comparison of geologic and drillers well logs for locations in the Blue Lake area shows that interpretations of the geologists and drillers are very similar. Differences exist mostly in the interpretation of grain size and cementation in units adjacent and below the Blue Lake gravel aquifer. Hartford and McFarland (1989) describe the Blue Lake gravel aquifer as coarse channel deposits of the ancestral columbia River. This paleochannel has eroded into the Troutdale Formation and subsequently filled with coarse flood deposits. This suggests that the aquifer sediments are late Pleistocene in age corresponding with the catastrophic floods described by Bretz and others (1956). Mundorff 
(1964) describes an aquifer with very similar characteristics on the north side of the Columbia River in the Camas, Washington area. These descriptions are consistent with those found in the geologic and drillers well logs.

The sediments in the adjacent units are all fine grained, ranging from the clayey silt in the confining unit to the medium sand in the Troutdale Sandstone aquifer. This is a sharp contrast to the clast supported coarse gravel and cobble deposits of the Blue Lake gravel aquifer. The aquifer sediments are easily distinguishable from the adjacent units.

The elevations of the top and bottom of the aquifer (see Table I) were compared to those presented by Hartford and McFarland (1989). These data were found to be in general agreement for locations common to their work and this study.

Figure 7 shows the elevation of the top of the aquifer, modified from Hartford and McFarland (1989). A notable high of 6.7 meters is present along the east side of the north shore of Blue Lake. From that area the elevation decreases gently to the northwest and more sharply to the south and northeast.

Figure 8 shows the elevation of the bottom of the aquifer, modified from Hartford and McFarland (1989). The bottom of the aquifer shows a distinct deepening trend to the east. The minimum depth encountered was 70.7 meters at 
wells 1 and 2. The pattern formed by the contours and the easterly dip indicate an east-west aligned trough, dipping to the east.

The southern and western extent of the aquifer follows the ridge of Troutdale sandstone from the south side of Blue Lake to Taggart Bluff to the northwest (Hartford and McFarland, 1989). As noted by Hartford and McFarland (1989), the eastern extent is not clearly defined due to a lack of available data.

Figure 9 is a north-south oriented hydrogeologic section. The ridge-forming Troutdale Sandstone can be seen bounding the aquifer to the south of Blue Lake. The northern extent projects to just north of the south shore of the Columbia River, where the submerged gravel, cobble, and boulders were observed. The Columbia River Sands described by Hoffstetter (1981) are interpreted to project below the Columbia River, terminating the Blue Lake gravel aquifer to the north.

Drawdown data are shown plotted with a Theis type curve in Figures 10 and 11. The estimated transmissivities and storage coefficients are $17,740 \mathrm{~m}^{2} /$ day and .008 respectively for well 6 , and $16,760 \mathrm{~m}^{2} /$ day and .009 respectively for well 9. The lack of early data for the time immediately after pumping started make this data less than adequate for use. The deviation from the curve at about 4 days is small but pronounced for both wells. This corresponds to the break in 


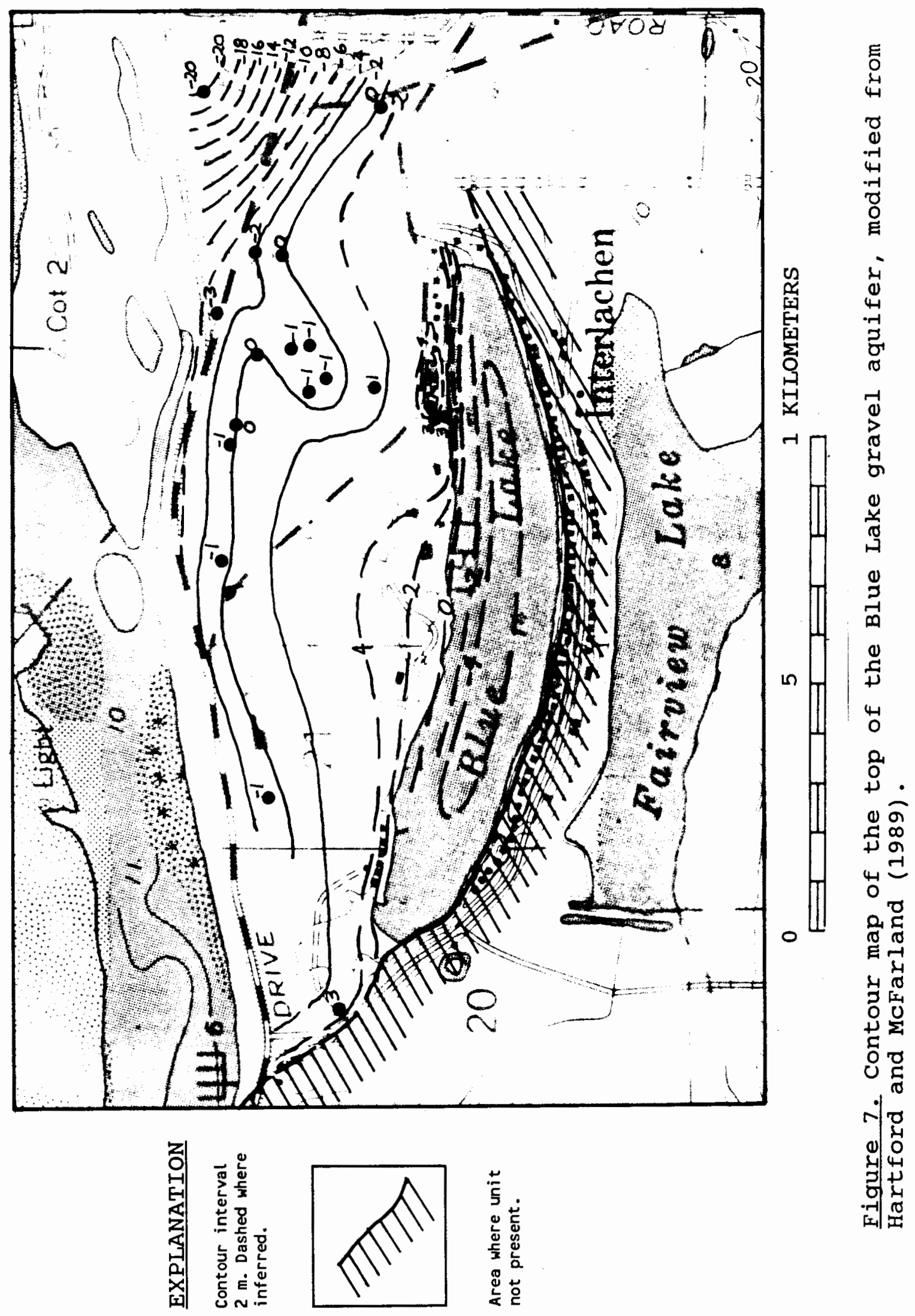




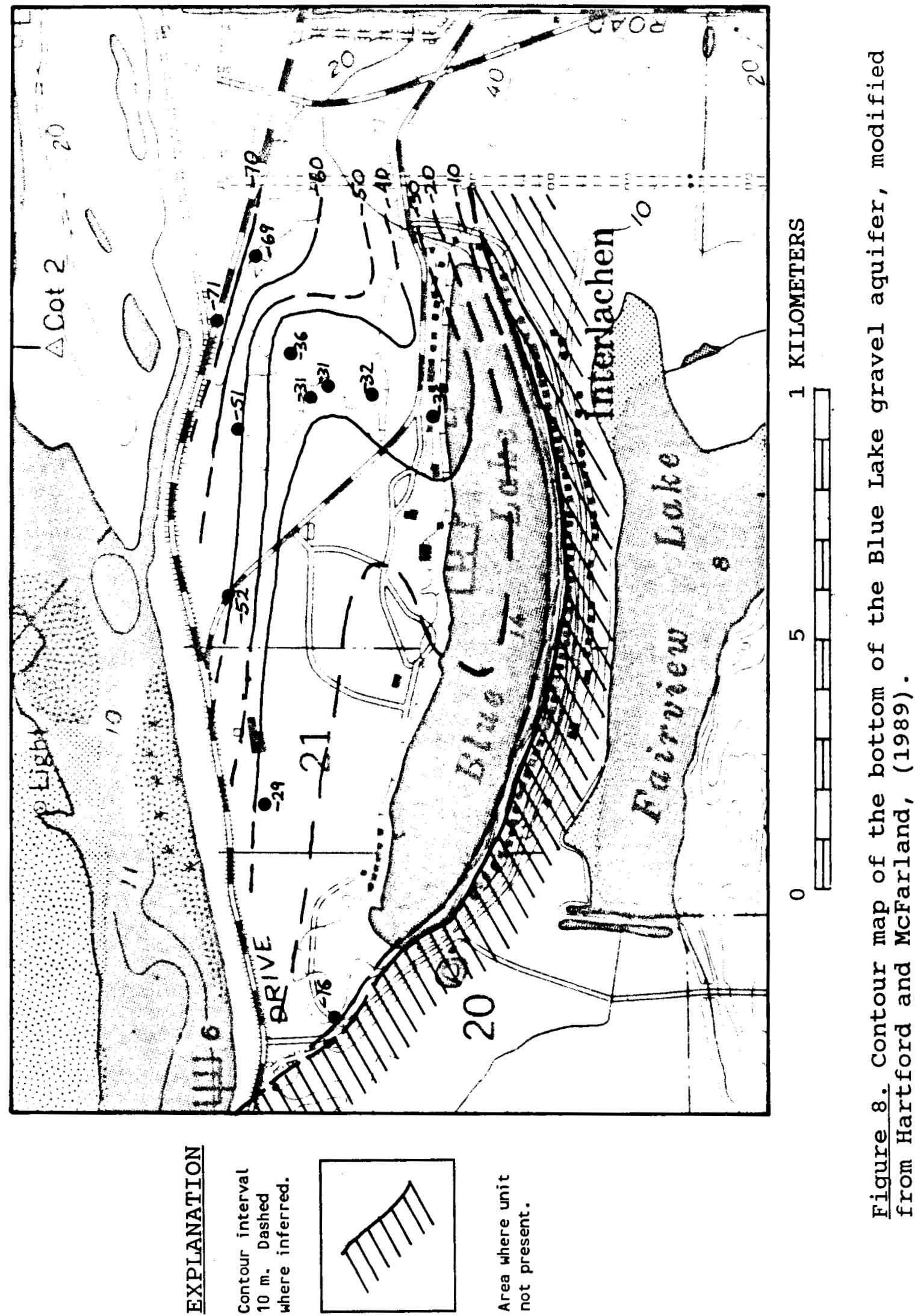


A $A^{\prime}$

(meters)

(meters)
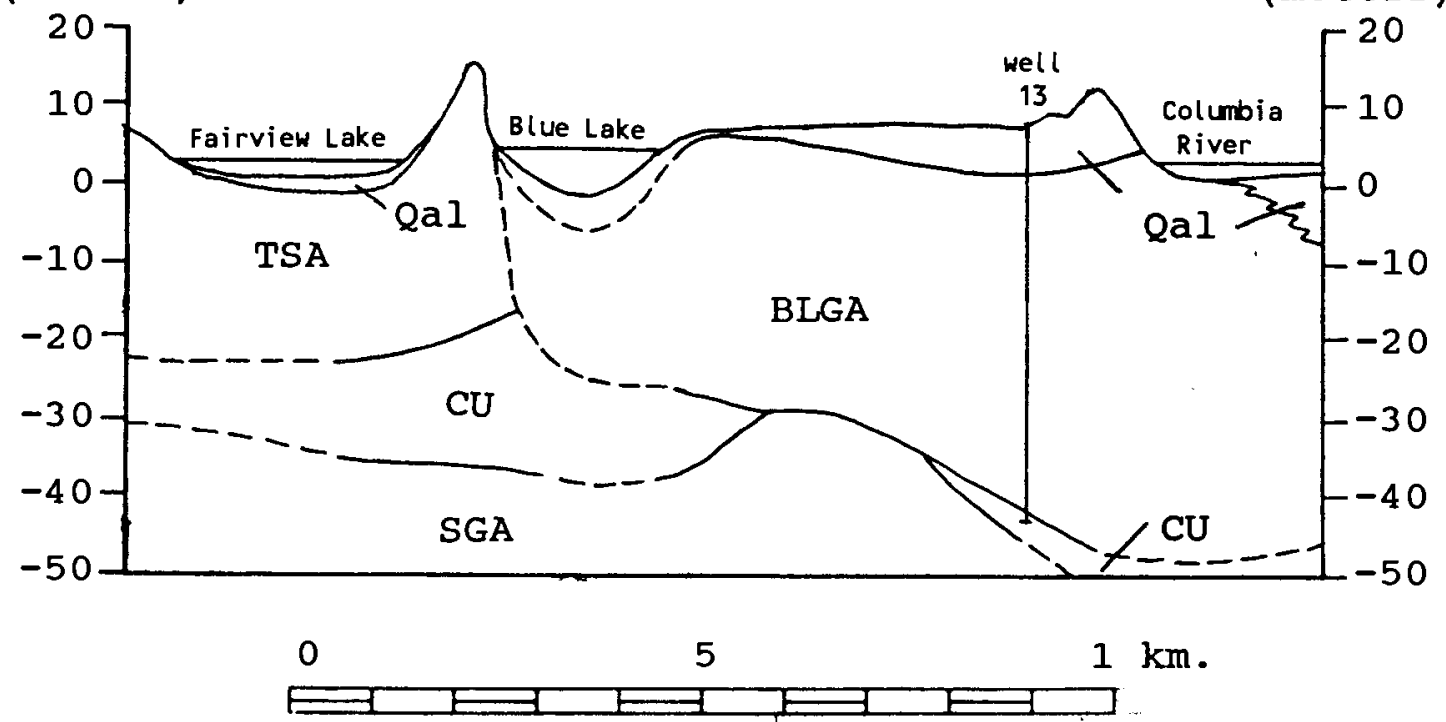

\section{EXPLANATION}

BLGA Blue Lake Gravel Aquifer

Qal Recent Alluvium

TSA Troutdale Sandstone Aquifer

CU Confining Unit

SGA . Sand and Gravel Aquifer

Figure 9. North-south hydrogeologic section through the Blue Lake area. 
$1 / \mathrm{u}$

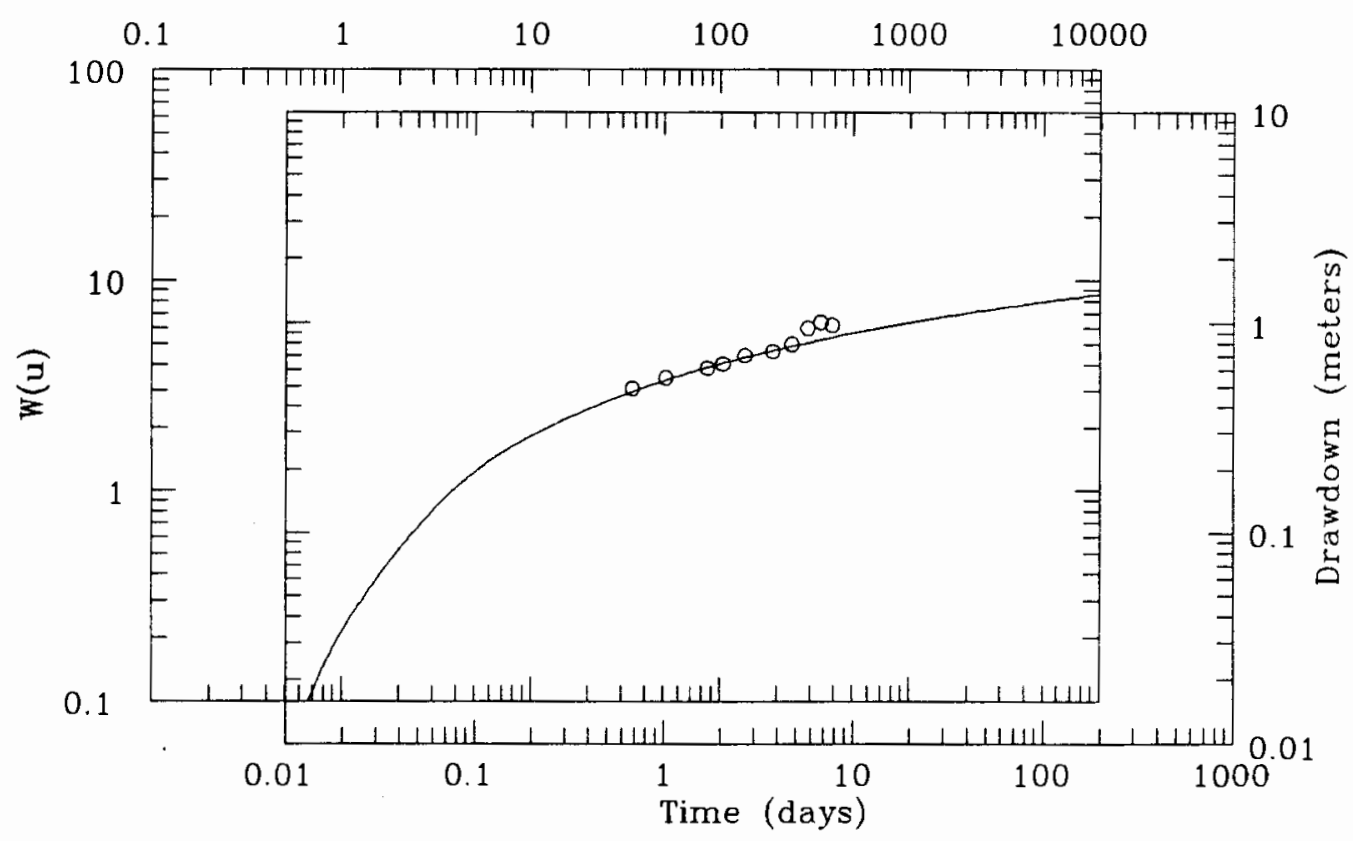

Figure 10. Drawdown data for well 6 with Theis type curve.

slope shown in Figures 4 and 5. This condition is indicative of an impermeable boundary being sensed (Driscoll, 1986; Heath, 1982).

The distance to the hydraulic boundary can be calculated using the relationship

$$
r_{\iota}=r_{\sigma}\left(t_{\iota} / t_{\sigma}\right)^{1 / 2}
$$

where $r_{\iota}$ is the distance from the observation well to the image well, $r_{\sigma}$ is the distance from the observation well to the pumping well, $t_{1}$ is the time at which a drawdown $s_{\text {。 }}$ caused by the image well at the observation well, and $t_{\sigma}$ is the time at which a drawdown of $s_{\sigma}$ is caused by the real 


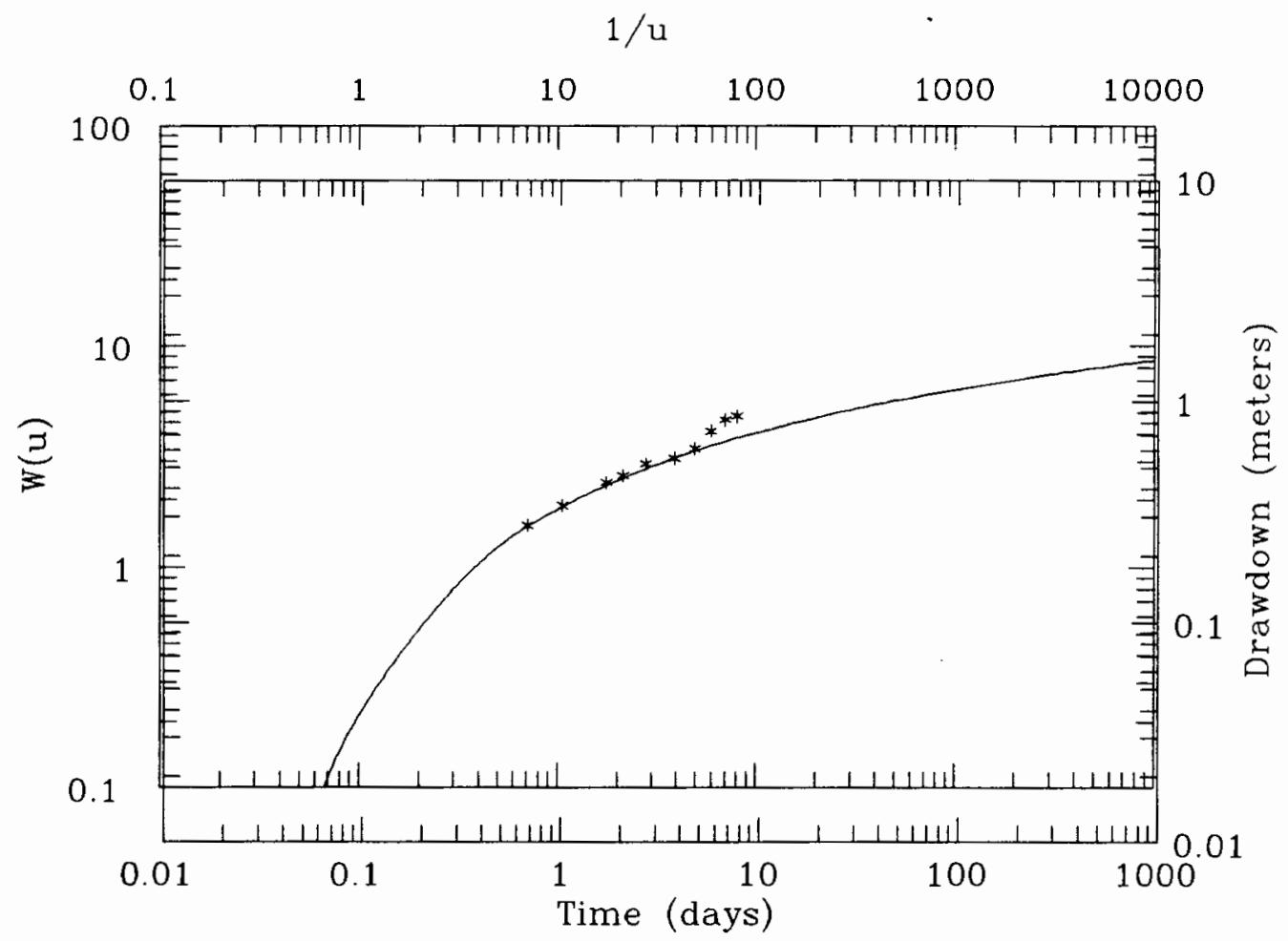

Figure 11. Drawdown data for well 9 with Theis type curve.

pumping well at the observation well (Heath, 1982). Equation 6 assumes $s_{\iota}=s_{\sigma}$. Since the boundary is halfway between the observation well and the image well, the distance of the boundary becomes $r_{\downarrow} / 2$ from a point halfway from the pumping well to the observation well (Heath, 1982). Based on these assumptions and conditions, the hydraulic boundary is calculated to be approximately 5,000 meters away. This distance is a hydraulic distance which is influenced by other hydrauIic conditions and therefore does not represent the true distance. The relationship of the aquifer to the columbia River shown in Figure 9 suggests that there may be a strong recharge boundary influencing the hydraulic conditions. 
Assuming a recharge influence from the columbia River, the boundary is probably much closer than 5,000 meters and represents the TSA.

The City of Portland has conducted several pump tests in the Blue Lake gravel aquifer from which hydraulic conductivities from 600 to $900 \mathrm{~m} /$ day have been estimated ( $\mathrm{w}$. McFarland, personal communication). The expected range of values for gravels is about 100 to $6,000 \mathrm{~m} /$ day (Heath, 1982). Values of 560 to $683 \mathrm{~m} /$ day calculated from the August 1990 pump test data are consistent with previous estimates and the expected range. 
CHAPTER III

STABLE ISOTOPE ANALYSIS

METHODS OF INVESTIGATION

The traditional method of determining the relationship between an aquifer and a surface water body involves comparing water levels to determine the hydraulic gradient and measuring discharge along a stream. Another method is the use of naturally occurring stable isotopes as a natural tracer. This method can be used independently from traditional methods as a tool for corroborating or refuting hypotheses based on the traditional approach. In this study, stable isotopes of hydrogen and oxygen were used to determine the hydraulic relationship between the Blue Lake gravel aquifer and two surface water bodies, the columbia River and Blue Lake. The two questions addressed are: 1) Is the Blue Lake gravel aquifer hydraulically connected to the Columbia River and/or Blue Lake?, and 2) What is the contribution of the Columbia River and Blue Lake to the pumping wells?

In March 1990, the City of Portland conducted a pump test, pumping five production wells (wells 12, 13, 17, 18, 19; see Figure 2 for locations) at a combined rate of 118 $\mathrm{m}^{3} / \mathrm{min}$. All of these wells are completed in the Blue Lake 
gravel aquifer. This provided an opportunity to collect water samples for stable isotope analysis under stressed hydraulic conditions.

Before, during and after this test, water samples were collected from the production wells (wells 12, 13, 17, 18, 19), observation wells (wells $1,2,3,4,5,9,10$ ), the Columbia River, the Sandy River, and Blue Lake (see figure 2). Samples were collected with U.S.G.S. equipment and supplies by U.S.G.S. personnel including myself.

The procedure for sampling was developed by laboratory personnel at the Portland U.S.G.S. office. Prior to sampling at each observation well, the well was purged and the $\mathrm{pH}$, specific conductance, and temperature of the effluent was monitored. Samples were taken after these parameters had stabilized and been recorded. A pneumatic pump using nitrogen was used for pumping water from the area adjacent to the well screen. Samples were collected by filling $50 \mathrm{ml}$ glass bottles and sealing them with polyseal caps to minimize any effects from headspace. Samples taken from the production wells were collected directly from outlets at the wells. Samples collected from the Columbia River, Sandy River, and Blue Lake were obtained with a bailer lowered to a depth equal to half of the total depth at the collection location. These samples were also collected in $50 \mathrm{ml}$ glass bottles with polyseal caps. Samples selected for analysis were sent to the U.S.G.S. Water Quality Laboratory in Menlo 
Park, California where concentrations of oxygen ${ }^{18}$ and deuterium were determined using mass spectrometry (K. McCarthy, personal communication). The data are expressed as per mil values of the isotopic ratios $\mathrm{D} / \mathrm{H}$ and ${ }^{18} \mathrm{O} /{ }^{16} \mathrm{O}$ relative to standard mean ocean water (SMOW) (Craig, 1961). The isotopic ratios are defined as

$$
\begin{aligned}
& \delta^{18} \mathrm{O}(\text { per mil })=\left(\left(\left({ }^{18} \mathrm{O} /{ }^{16} \mathrm{O}\right)_{\text {sample }} /\left({ }^{18} \mathrm{O} /{ }^{16} \mathrm{O}\right)_{\text {sMow }}\right)-1\right) 1000 \\
& \delta \mathrm{D}(\text { per mil })=\left(\left(\left({ }^{2} \mathrm{H} /{ }^{1} \mathrm{H}\right)_{\text {sample }} /\left({ }^{2} \mathrm{H} /{ }^{1} \mathrm{H}\right)_{\text {sMow }}\right)-1\right) 1000
\end{aligned}
$$

for concentrations of ${ }^{18} \mathrm{O},{ }^{16} \mathrm{O},{ }^{2} \mathrm{H},{ }^{1} \mathrm{H}$.

The pump test of August 1990 provided another opportunity for sample collection. Samples were collected daily at the pumping well (well 19) for the 22 day duration of the test. The collection procedure was the same as that used in March and selected samples were analyzed by the same laboratory and procedure.

\section{RESULTS}

The results of the analysis of the water samples are shown in Table IV. The standard deviations of the reported data are 0.1 per mil for oxygen ${ }^{18}$ and 1.5 per mil for deuterium.

\section{DISCUSSION}

Figure 12 shows isotopic compositions of samples collected prior to the initiation of the pump test, relative to the global meteoric water Iine (Craig, 1961). The isotopic 
TABLE IV

OXYGEN $^{18}$ AND DEUTERIUM VALUES FOR WATER SAMPLES COLLECTED IN MARCH AND AUGUST 1990

(RELATIVE TO SMOW)

\begin{tabular}{cccc}
$\begin{array}{c}\text { Well } \\
\text { ID }\end{array}$ & $\begin{array}{c}\text { Sample } \\
\text { Date }\end{array}$ & $\begin{array}{c}\delta^{18} \text { o } \\
\text { per mil) }\end{array}$ & $\begin{array}{c}\delta D \\
\text { (per mil) }\end{array}$ \\
\hline 19 & $03 / 05 / 90$ & -10.6 & -78.0 \\
& $03 / 11 / 90$ & -12.9 & -99.0 \\
& $08 / 10 / 90$ & -12.2 & -94.0 \\
& $08 / 13 / 90$ & -12.5 & -100.0 \\
& $08 / 16 / 90$ & -12.7 & -102.0 \\
& $08 / 19 / 90$ & -12.8 & -102.0 \\
& $08 / 22 / 90$ & -13.5 & -106.0 \\
& $08 / 25 / 90$ & -13.6 & -106.0 \\
13 & $08 / 29 / 90$ & -13.9 & -109.0 \\
& $03 / 05 / 90$ & -11.5 & -84.0 \\
17 & $03 / 12 / 90$ & -13.2 & -100.0 \\
& $03 / 05 / 90$ & -11.5 & -81.0 \\
1 & $03 / 12 / 90$ & -12.8 & -98.0 \\
& $03 / 02 / 90$ & -9.2 & -71.0 \\
2 & $03 / 14 / 91$ & -11.4 & -85.0 \\
& $03 / 06 / 90$ & -10.2 & -71.0 \\
18 & $03 / 14 / 90$ & -10.1 & -75.0 \\
& $03 / 05 / 90$ & -10.0 & -73.0 \\
12 & $03 / 12 / 90$ & -10.0 & -77.0 \\
& $03 / 05 / 90$ & -9.7 & -69.0 \\
3 & $03 / 11 / 90$ & -9.4 & -68.0 \\
4 & $03 / 02 / 90$ & -9.3 & -68.5 \\
& $03 / 02 / 90$ & -10.2 & -67.5 \\
5 & $03 / 14 / 90$ & -8.3 & -68.0 \\
& $03 / 02 / 90$ & -9.8 & -72.0 \\
9 & $03 / 09 / 90$ & -10.2 & -75.0 \\
& $03 / 02 / 90$ & -9.3 & -70.0 \\
10 & $03 / 09 / 90$ & -9.8 & -68.0 \\
& $03 / 02 / 90$ & -8.0 & -65.0 \\
& & &
\end{tabular}

compositions of samples from the aquifer and the sandy River form a cluster along the meteoric water line. The water of the columbia River is significantly depleted in the heavy isotopes relative to local waters. The isotopic composition of Blue Lake appears to represent a point on an evaporation trajectory (Craig, 1961; Domenico and Schwartz, 1990) origi- 


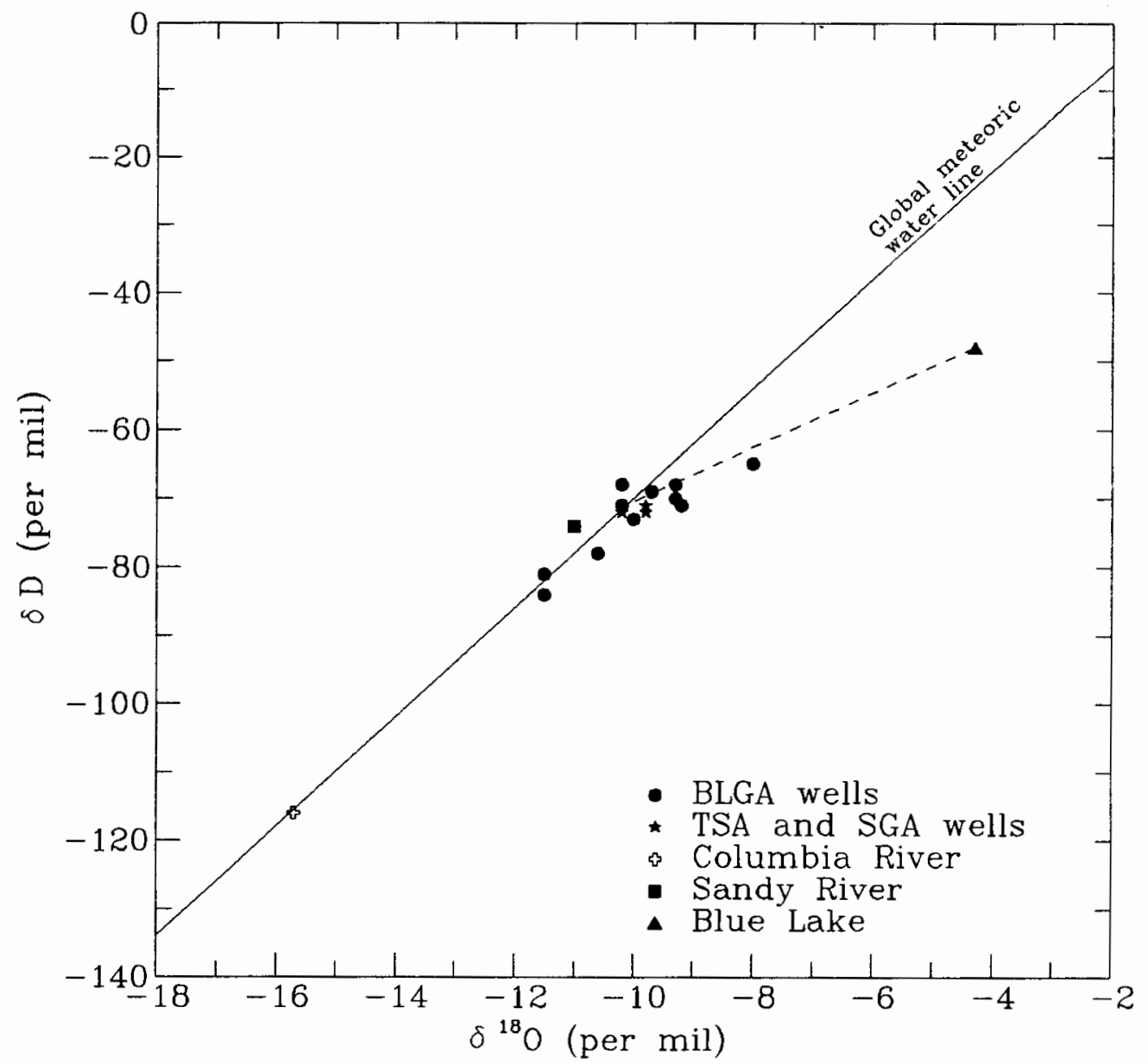

Figure 12. Initial composition of oxygen ${ }^{18}$ and deuterium before pumping.

nating from the cluster. Well 10, a shallow well adjacent to Blue Lake, has a water sample isotopic composition which falls along the Blue Lake evaporation trajectory. These initial values establish the isotopic signatures which characterize the different water sources.

Figure 13 shows initial and subsequent isotopic compositions in selected wells. All of these water samples show a significant shift in isotopic composition after 


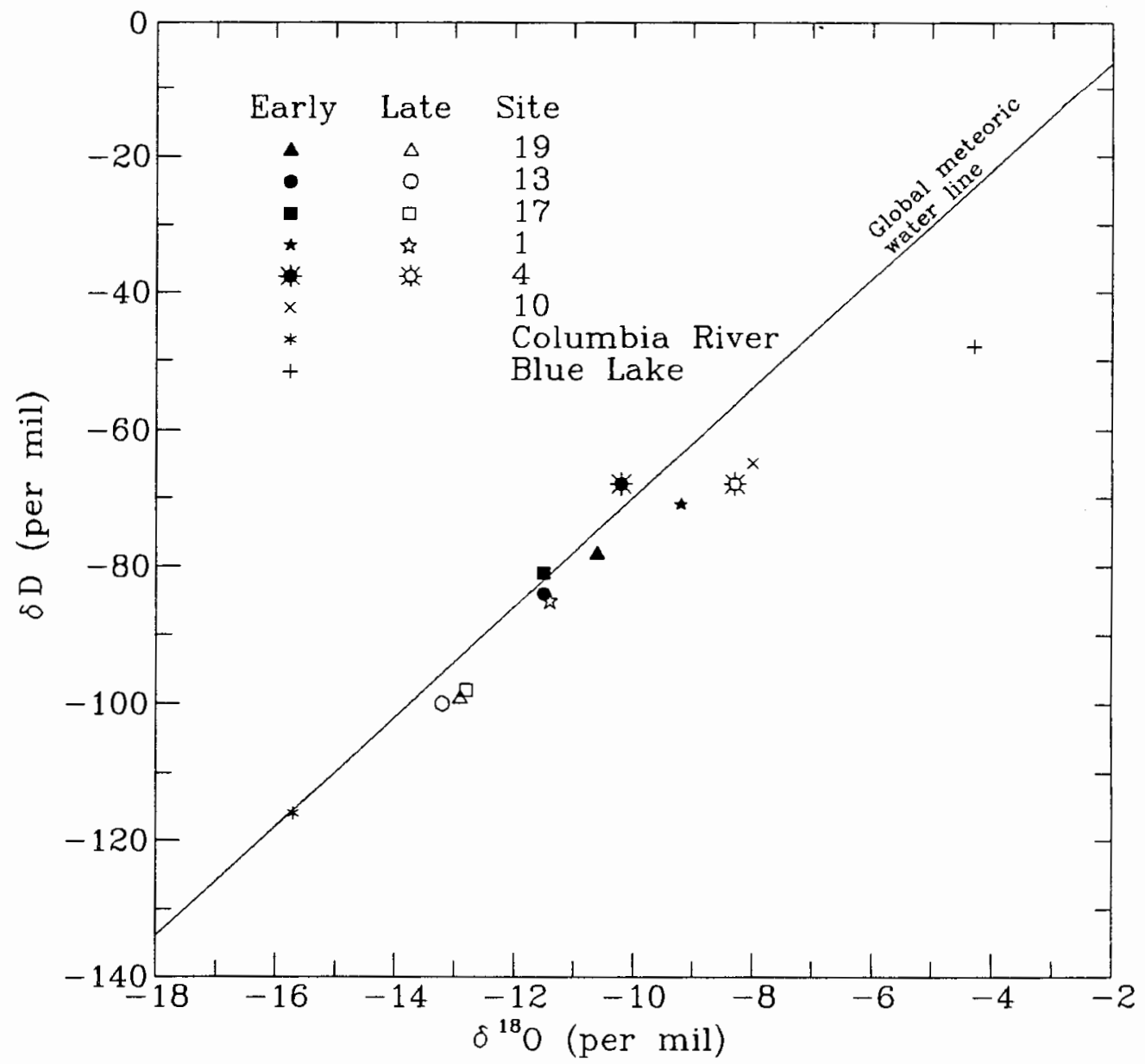

Figure 13. Initial vs. late compositions of oxygen ${ }^{18}$ and deuterium for selected locations.

pumping started. All of those which shifted toward the Columbia River are from wells proximal to the river. The sample which shifted in the general direction of Blue Lake is from well 4, located closer to Blue Lake, and suggests that the pumping drew the aquifer - Blue Lake transition zone closer to that well.

Assuming that the initial contribution of the river to the well is zero, and the isotopic composition of the colum- 
bia River is constant, the percent contribution of water from the Columbia River to the pumping wells can be estimated using simple mixing theory. The relationship is

$$
\mathrm{PR}_{v}=100\left(\mathrm{C}_{\imath}-\mathrm{C}_{v}\right) /\left(\mathrm{C}_{\imath}-\mathrm{CR}\right)
$$

where $\mathrm{PR}_{v}$ is the percent river contribution at time $t, c_{l}$ is the initial composition of the groundwater at the well, $c_{v}$ is the composition of the well water at time $t$, and CR is the composition of the columbia River.

The Sandy River is a relatively local drainage and the river water is representative of local meteoric water. The isotopic compositions of aquifer water samples are homogeneous as shown by the clustering in Figure 12. The isotopic composition of the Sandy River falls within this same cluster, indicating the aquifer water is of local origin. The Columbia River is a regional river which drains approximately $622,600 \mathrm{~km}^{2}$. This drainage basin is inland to the north and east of the study area. The depleted isotopic composition of the columbia River is characteristic of higher latitudes and inland regions (Domenico and schwartz, 1990). The isotopic composition of the columbia River is a composite of many sources and any one source is assumed to have an insignificant effect. Therefore the isotopic composition of the Columbia River is assumed to be constant.

Calculations were made using equation 7 based on these assumptions. Discharge from well 19 showed the largest percent contribution of river water with about $50 \%$ after six 
days. Well 13 had a $45 \%$ contribution from river water and well 17 had a 38 percent contribution after seven days. Water sampled from observation well 1 two days after pumping stopped showed a $33 \%$ contribution of river water. Although the $\delta D$ value in observation well 4 remained constant, the $\delta^{18} \mathrm{O}$ value shows a 2 per mil enrichment, suggesting about a $28 \%$ contribution of water from Blue Lake. The constant $\delta \mathrm{D}$ value at well 4 suggests that enough Columbia River water influenced the sample to hold the value steady. The amount of Columbia River water was probably relatively small, less than $10 \%$.

The results of the analysis of samples collected in August (well 19) are shown in Figure 14 with data from March for the same well superimposed on it. As in March, the isotopic composition shifted toward the composition of the Columbia River. Although a sample was not collected prior to pumping in August, a comparison of data from day 6 for August and March shows very similar compositions. One notable difference is that the August data are slightly enriched in $\delta^{18} 0$ values compared to March data. Although Blue Lake was not sampled during August, it is not unreasonable to assume a seasonal enrichment in heavy isotopes. The shift in the August data suggests a small contribution of Blue Lake water, probably less than 10\%. An estimate of percent contribution from the river can be calculated based on the assumptions that the isotopic composition of the 


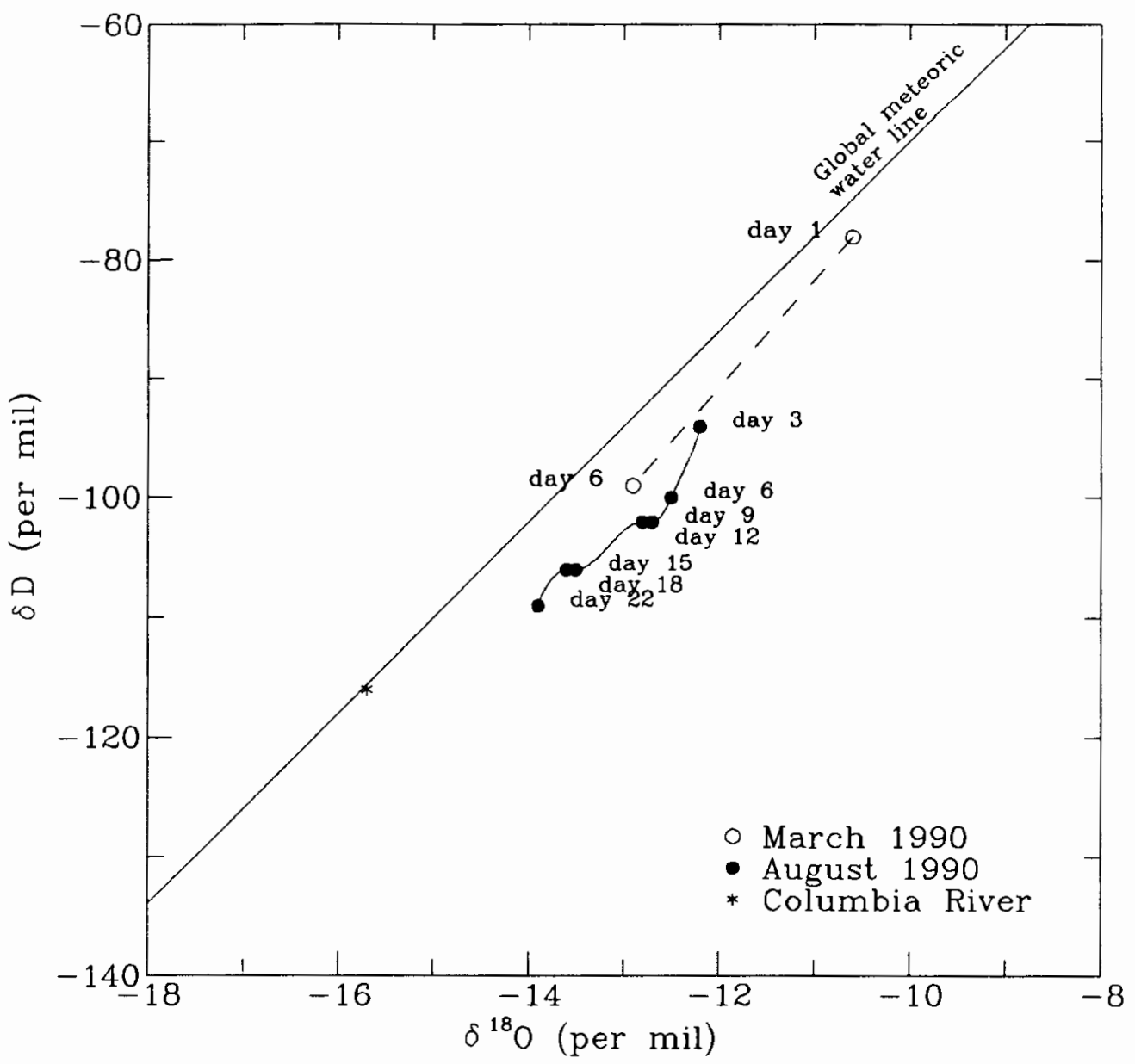

Figure 14. oxygen ${ }^{18}$ and deuterium compositions with respect to time for well 19.

Columbia River is nearly constant and that the initial

isotopic composition of water in well 19 is nearly identical to that of March. The estimated contribution is calculated to be about $72 \%$ water from the Columbia River after 22 days of pumping.

Figures 15 and 16 show the isotopic values of $\delta^{18} \mathrm{O}$ and $\delta \mathrm{D}$ with respect to time. The isotopic composition of well 19 water did not reach a point of equilibrium after 22 days 


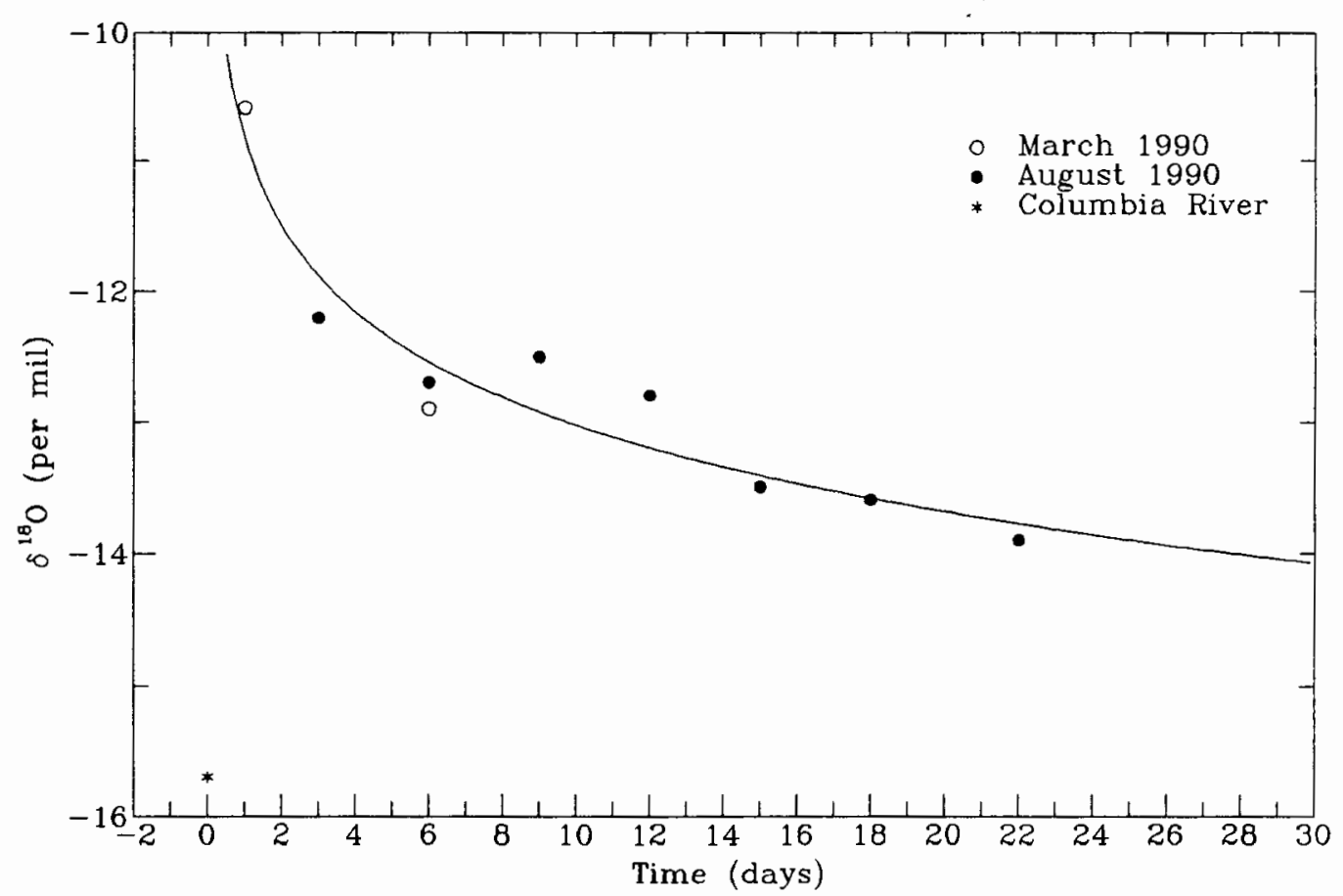

Figure 15. oxygen $^{18}$ vs. time, well 19.

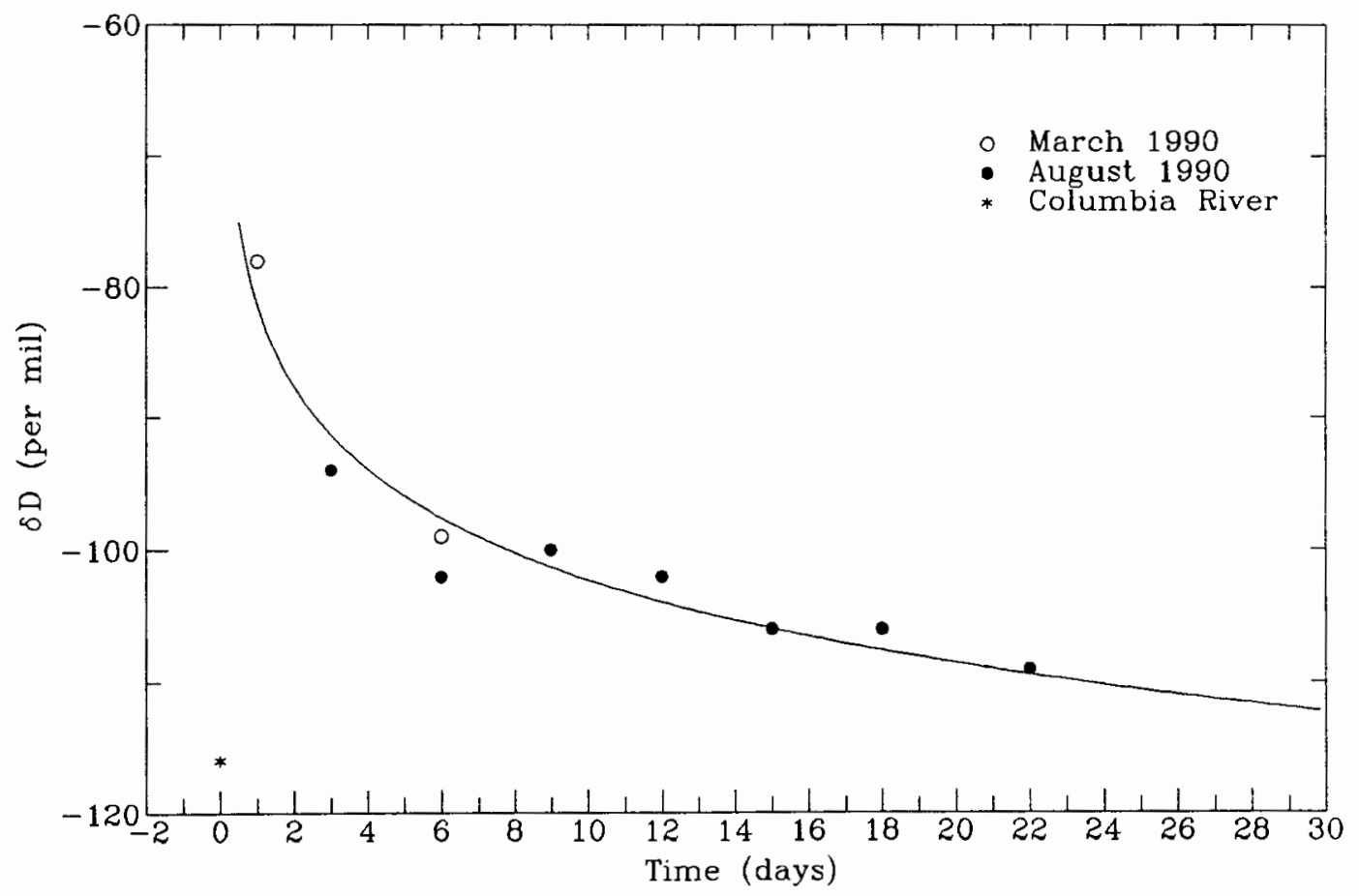

Figure 16. Deuterium vs. time, well 19. 
of pumping. It is assumed that the isotopic composition will reach an equilibrium point at some point in time. By evaluating the components separately and projecting the trends with respect to time, a range of percent contribution can be established using the same relationship outlined earlier. These data can then be combined to give an estimated contribution at the projected point of equilibrium.

The trend of the data appears to be exponential, therefore an exponential best fit line was applied to the data and projected beyond 22 days. Equilibrium was arbitrarily chosen as the point at which the change is less than $0.3 \%$ of the isotopic value for the same period of time for both components. Using these parameters, a range of $73 \%$ to $94 \%$ is estimated. By using $\delta^{18} O$ and $\delta D$ values from this equilibrium point, an estimated contribution can be calculated. Using these projected values a contribution of about $82 \%$ water from the Columbia River can be expected after 30 days of pumping. 


\section{CHAPTER IV}

\section{WATER LEVEL ANALYSIS}

\section{METHODS OF INVESTIGATION}

Water levels in the Blue Lake area were monitored to determine the relationships of the Blue Lake gravel aquifer, Blue Lake, and the Columbia River. Barometric pressure and precipitation were also monitored.

The U.S.G.S. supplied a Campbell Scientific Incorporated model CR21 digital recorder for recording the water level in the aquifer. It utilized a float and counterweight attached to a ten turn precision linear potentiometer. The circumference of the pulley on the potentiometer was 30.5 centimeters, giving the apparatus a 3 meter range of motion for water levels. The recorder was programmed to record the instantaneous water level at 30 minute intervals. The potentiometer has a rated accuracy of $\pm 1.0 \%$. The sensitivity of the apparatus was 6 millimeters. A frame was constructed to which the potentiometer apparatus was mounted. The frame was clamped to the well casing and the digital recorder enclosed in an airtight container. The entire assembly fit inside the well vault.

A water level recorder was installed in well 6 (see Figure 2 for location) in October, 1990. An additional 
recorder was installed in well 4 in January, 1991. Both recorders monitored water levels continuously until April, 1991 when they were removed. Both sites were visited semimonthly to download data and manually measure the water level with a steel tape. The difference between actual and recorded water levels was calculated and used as a correction factor for the recorded data. Elevations at the top of the wells had been previously surveyed by U.S.G.S. personnel and reference the National Geodetic Vertical Datum of 1929.

The water stage in the columbia River was obtained from the U.S.G.S. in 30 minute intervals from october, 1990 until April, 1991. The source of the data is a water stage recorder located on the Columbia River at Washougal, Washington (river mile 122.9). The datum for this recorder is along a variable columbia River datum. Blue Lake is adjacent to river mile 118 .

A microbarograph located at the U.S.G.S. in Portland, oregon was the source of barometric pressure data. The microbarograph is a drum recorder which monitors barometric pressure continuously. The paper record was digitized to convert it to digital format in 30 minute intervals from October, 1990 until April, 1991. The microbarograph was monitored and found to have a timing error of no more than 10 minutes per week. Correction of barometric pressure for altitude was unnecessary because absolute magnitude was not used. 
Values for precipitation were obtained from the National weather Service in digital format. These were daily totals as measured at the Portland International Airport.

The water level in Blue Lake was not recorded. It is generally maintained at an elevation of 4.6 meters with a seasonal fluctuation of 0.3 meters (Hoffstetter, 1981).

A subset of data was selected from the overall data based on continuity. From this subset of data, water levels in the aquifer were cross-correlated with each other and with the Columbia River using the computer program CROSS. A listing of CROSS can be found in Appendix C. Precipitation and barometric pressure were examined visually.

\section{RESULTS}

Data for the month of February, 1991 were selected for analysis because they contain uninterrupted records of data for all five parameters, wells 4 and 6 water levels, columbia River water level, barometric pressure, and precipitation. The data can be found in Appendix B. A correction factor was obtained by calculating the difference in recorded and measured water levels in the aquifer. This correction factor was applied to the aquifer water level data to obtain true water level elevations.

\section{DISCUSSION}

The data are shown in Figures 17, 18, 19, 20, and 21. 
These figures show that there are some very obvious trends among the data sets. The strongest obvious effect on aquifer water levels is the Columbia River stage.

The Columbia River stage shows a considerable amount of fluctuation and periodicity (Figure 17). The period of the fluctuation is about two cycles per day, suggesting a strong tidal effect. The same tidal fluctuations can be seen to a lesser degree in the water level data of well 6 (Figure 18). water level data of well 4 does not appear to be strongly influenced by tides (Figure 19). Instead it has the appearance of an averaged Columbia River stage. Any effects of local barometric pressure (Figure 20) and precipitation (Figure 21) appear to be overshadowed by the influence of the Columbia River.

The data for water levels in the aquifer and the columbia River were analyzed using cross-correlation to determine the strength of the relationship and the offset in time phase. Figure 22 shows a plot of the correlation coefficient for water levels in well 6 and the Columbia River. The correlation for this relationship is 0.96 . The significance of the correlation coefficient can be tested statistically to determine the independence of the two data sets. The null hypothesis states that the two data sets are independent, random sequences (Davis, 1986). Based on the standard t-test, the null hypothesis is rejected for a significance level of $0.1 \%$. Therefore, the two data sets 


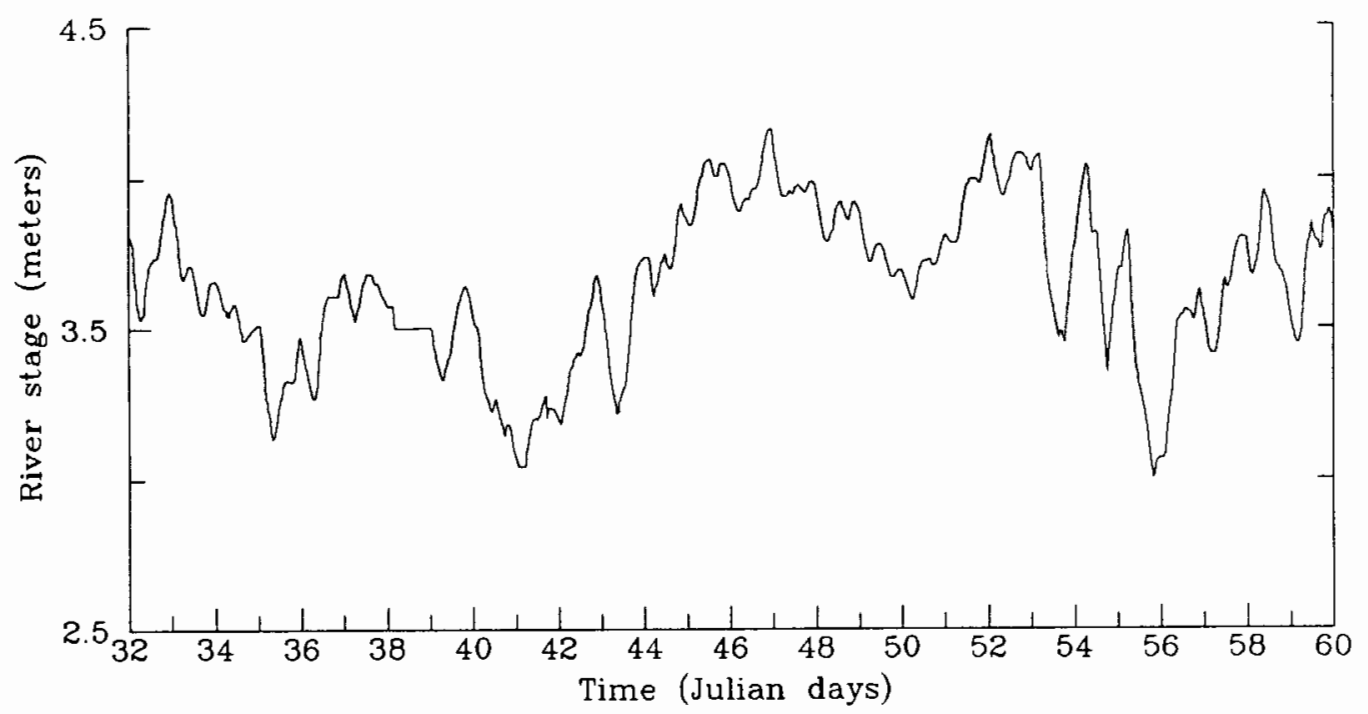

Figure 17. Columbia River stage, February, 1991.

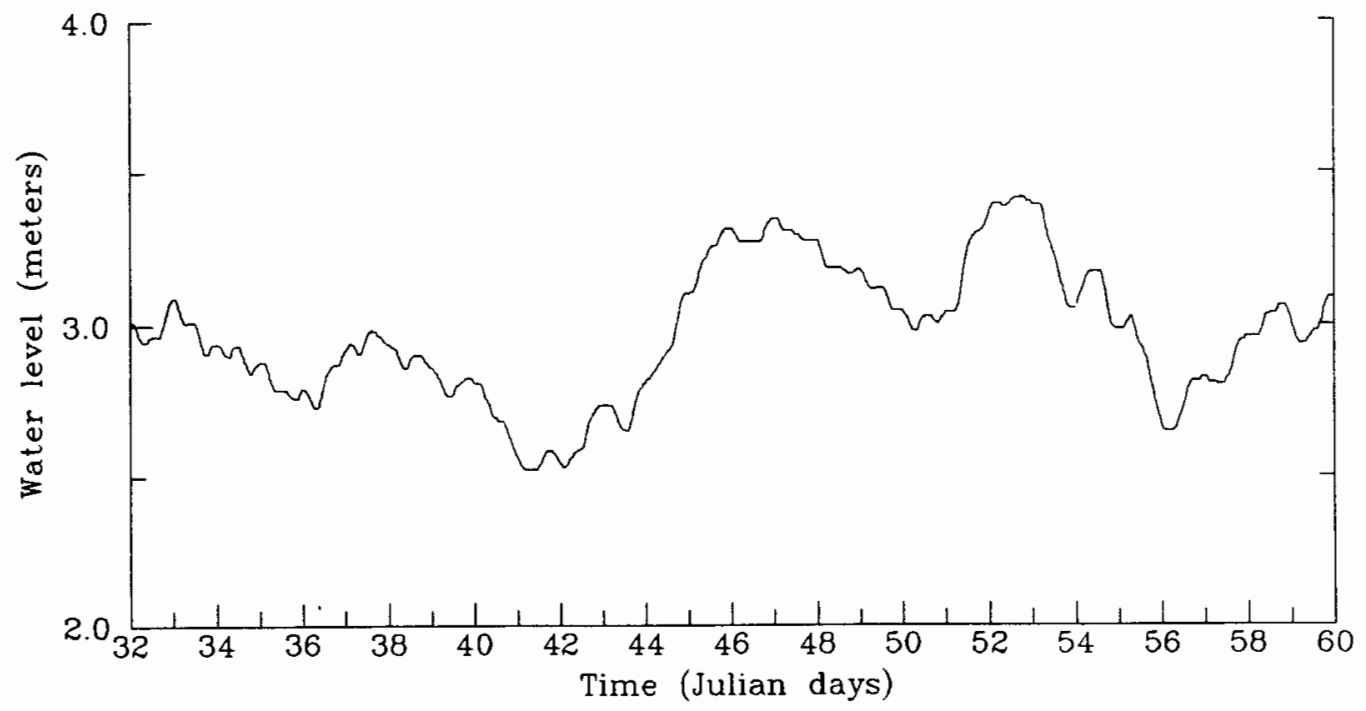

Figure 18. Water levels in well 6, February, 1991. 


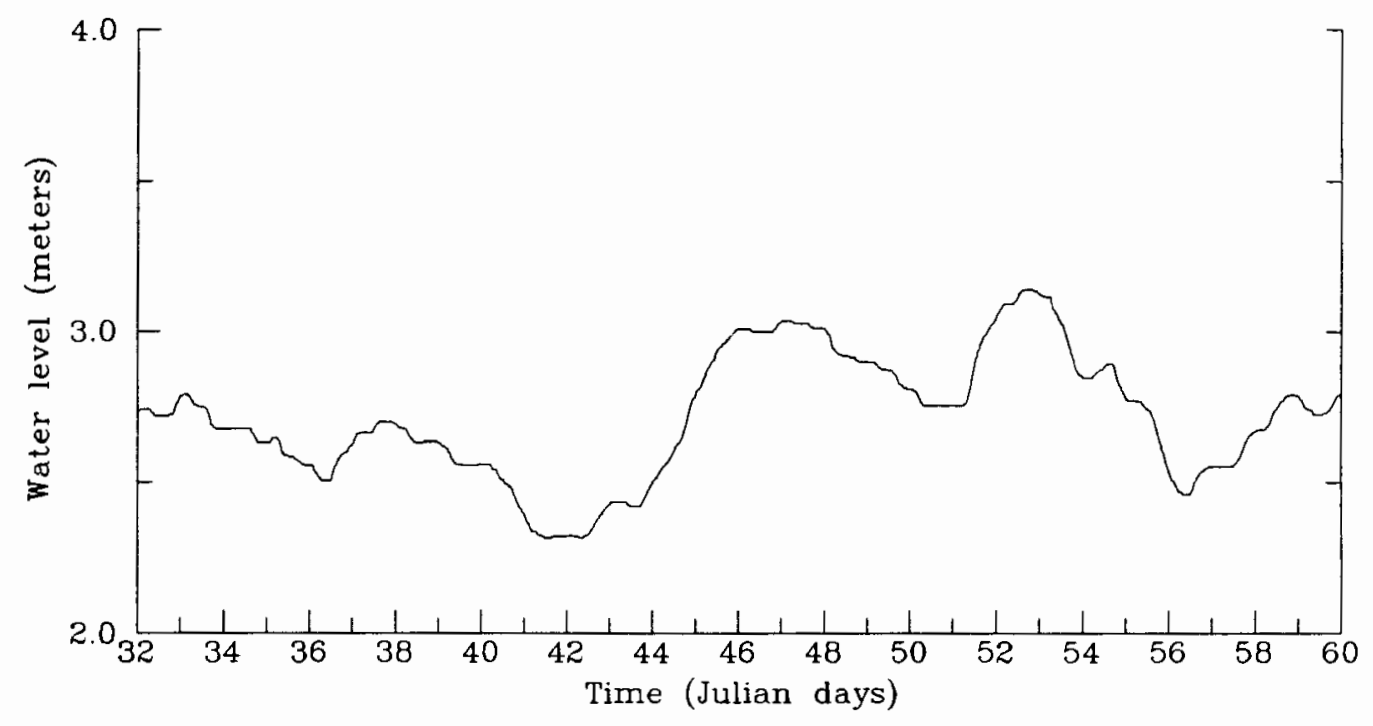

Figure 19. Water levels in well 4, February, 1991.

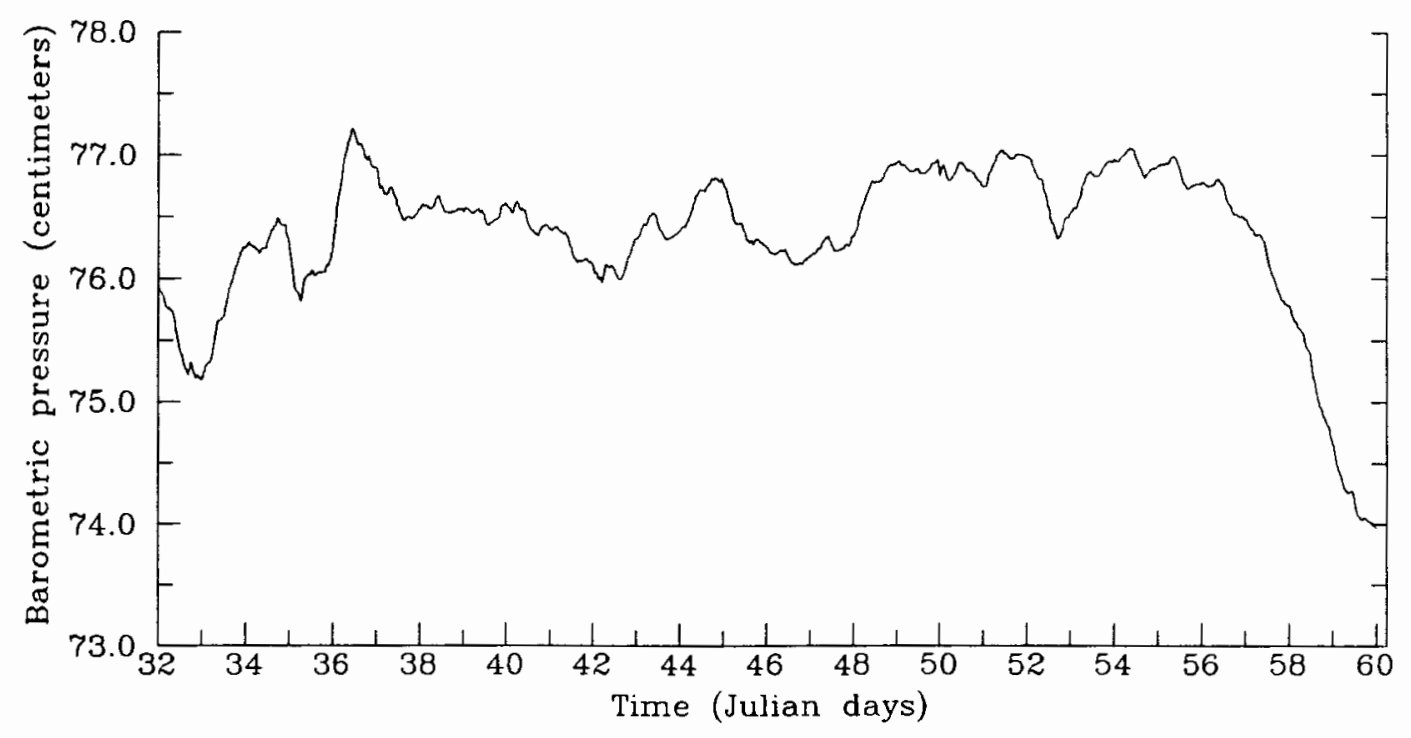

Figure 20. Barometric pressure, February, 1991. 


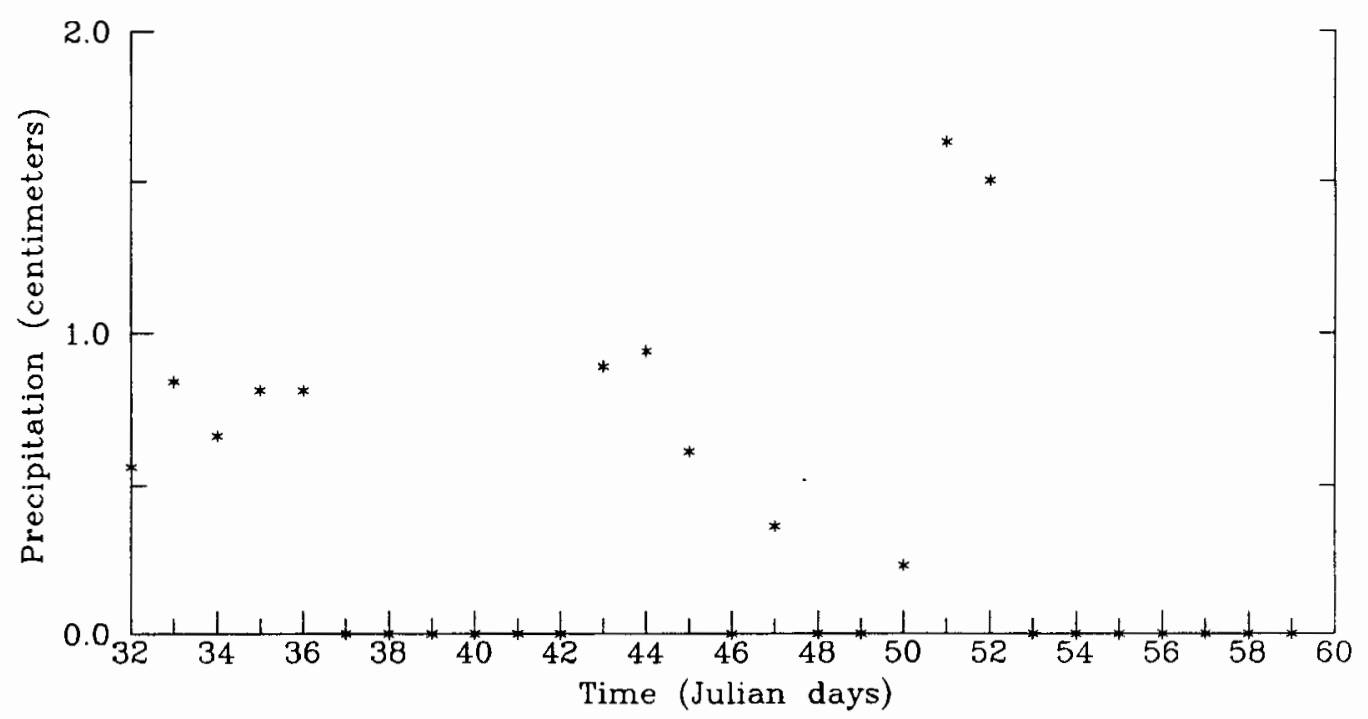

Figure 21. Precipitation, February, 1991.

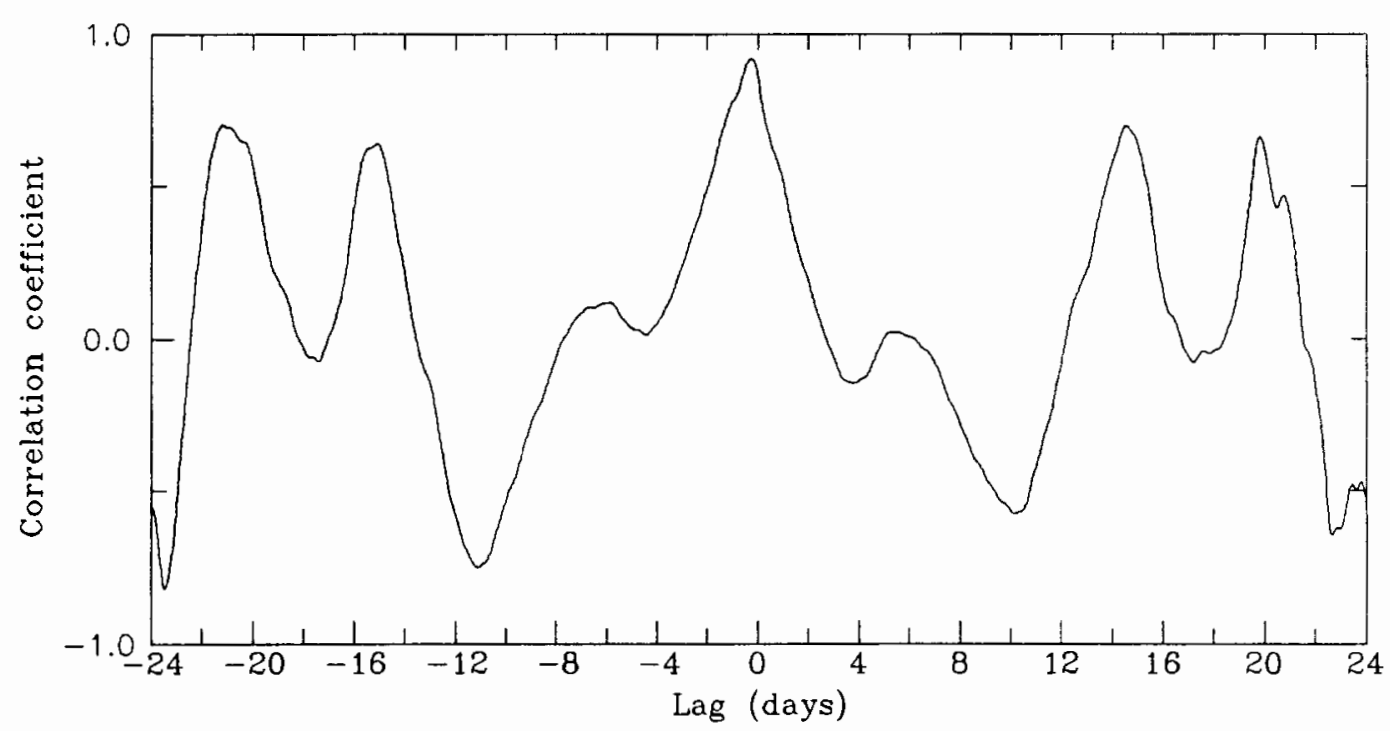

Figure 22. Correlogram for water levels in well 6 and the Columbia River. 
are not independent and the correlation is substantiated. The lag time to maximum correlation is about 3.5 hours and is indicative of the time it takes for the aquifer to respond to the river at well 6 .

Figure 23 shows the correlation coefficients for water levels in well 4 and the Columbia River. The strength of this correlation is 0.94 . Again, the statistical test substantiates this correlation as valid. The lag time for this maximum correlation is about 9 hours.

Figure 24 is a correlogram of water levels in wells 4 and 6. The correlation of these two data sets is 0.99 . From the statistical test, there is no evidence to suggest independence of the data sets, substantiating the strong correlation. This strong correlation suggests that the variations in the two data sets are nearly identical except for the lag and magnitude. The lag between well 4 and 6 is about 3.5 hours.

Lag times calculated include a correction for the difference in location of the river stage recorder. A correction factor of 20 minutes (L. Hubbard, personal communication) per mile was used to correct time lag estimates.

A comparison of figures 17,18 and 19 shows that the magnitude of the response of the aquifer to river stage decreases with distance. The small changes in river stage of less than 0.1 meters are not seen in the aquifer. Larger stage changes of 0.5 meters are translated to 0.13 meters in 


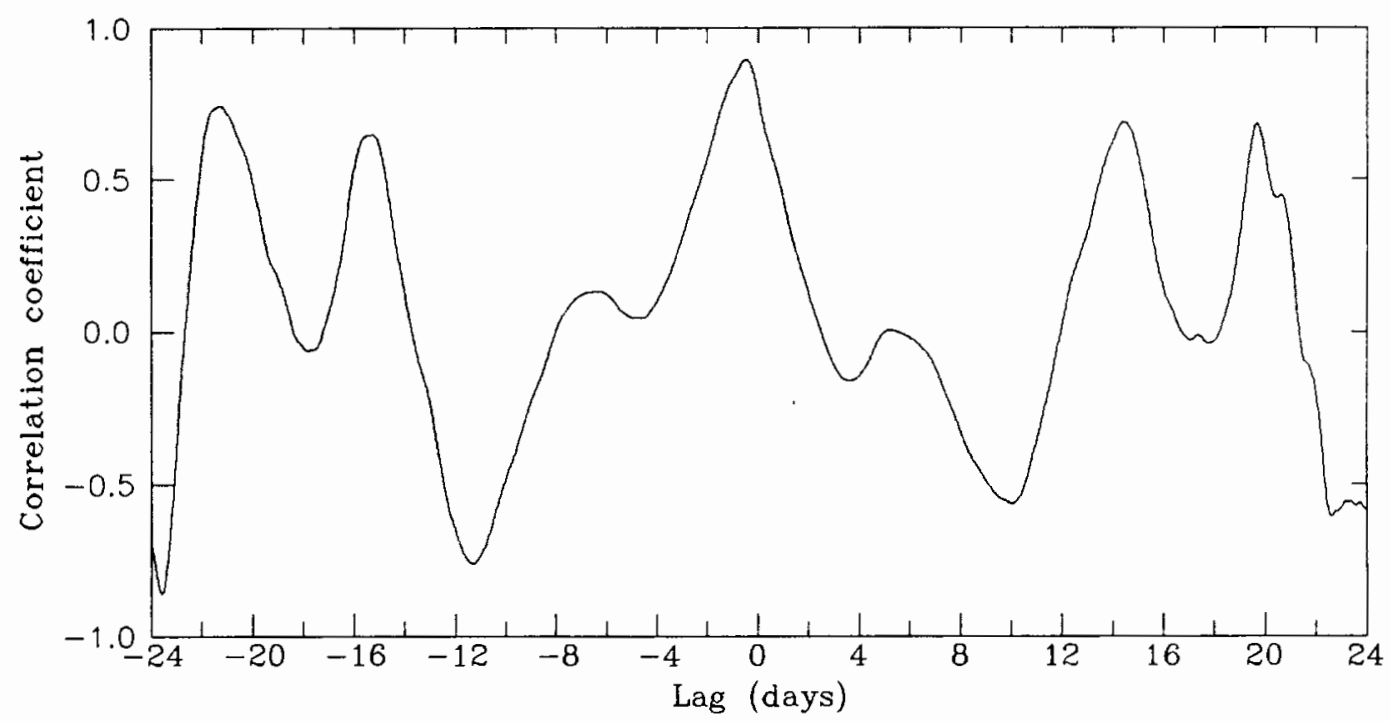

Figure 23. Correlogram for water levels in well 4 and the Columbia River.

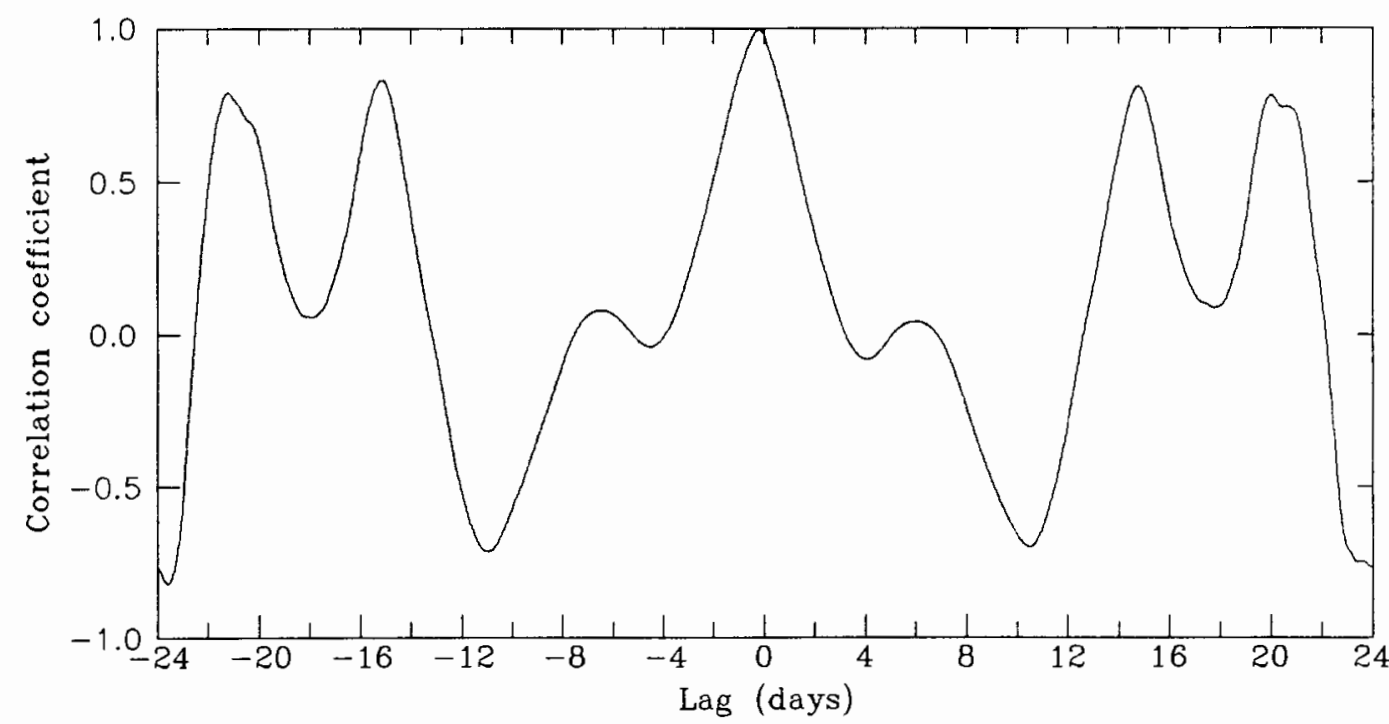

Figure 24. Correlogram for water levels in well 4 and 6 . 
well 6 and to 0.07 meters in well 4 . Well 6 is about 150 meters from the columbia River and well 4 is about 600 meters away. The magnitude of the response of the aquifer to the river is indeed inversely proportional to distance between them.

The relationship of water levels in Blue Lake and the aquifer has been shown when the level of the lake was lowered 3 meters in October, 1981 to alleviate a milfoil problem (Conley, 1981). The normal water level of Blue Lake is higher than in the aquifer and the subsequent lowering of the water level brought it down to an elevation equivalent to or lower than the water level in the aquifer. It was thought that the lake water level would recover naturally but this did not occur (W.D. McFarland, personal communication). The Troutdale sandstone on the south shore of the lake was assumed to be a source of recharge. If it is a source of recharge, it was insufficient to recover the water level in Blue Lake. In the october 1982 water was pumped into Blue Lake from well 12 and the Blue Lake water level was recovered. This event provides evidence that under static conditions, neither of the water sources has a significant effect on the other. 
CHAPTER V

CONCLUSIONS

The question of whether a hydraulic connection exists between the Blue Lake gravel aquifer and the Columbia River has been evaluated. The northern extent of the aquifer was shown to be in contact with the river along the south shore of the river. It is suggested that a hydraulic conduit exists in this area. The correlation of water levels between the river and aquifer shows that there is a definite response of the aquifer to the changes in river stage. This correlation does not provide evidence for exchange and mixing of water between the two. The evaluation of stable isotopic compositions shows that under stressed conditions, water from the Columbia River enters the aquifer and penetrates at least as far as the pumping wells.

On the basis of these evidences, it is concluded that the Blue Lake gravel aquifer has a strong hydraulic connection with the columbia River. Under stressed conditions the contribution of water from the river was estimated to be $72 \%$ and is significant. Under static conditions there is no evidence to suggest any significant mixing of waters. The hydraulic boundary between the river and the aquifer must be between the south shore of the columbia River and the well 
closest to it (well 6). This delineates a zone about 122 meters wide within which the boundary exists.

The hydraulic relationship between the aquifer and Blue Lake was also evaluated. Mapping of the aquifer sediments showed no evidence to suggest a hydraulic connection. Furthermore, analysis of water levels under static conditions showed no influence. However, analysis of isotopic compositions under stressed conditions shows a small influence of Blue Lake water.

These evidences indicate that there is a weak hydraulic connection between the aquifer and Blue Lake, but only under stressed conditions. Under all other circumstances Blue Lake is considered to be isolated from the aquifer.

A need for further research in this area is indicated by the lack of information about the eastern and northern extent of the aquifer. Moreover, the hydraulic relationship of the aquifer to adjacent hydrogeologic units is not defined. Additionally but not lastly, the absence of Blue Lake and Columbia River waters in samples taken under static conditions indicates that other possible sources of recharge to the aquifer need to be explored. 


\section{REFERENCES CITED}

Bretz, J.H., Smith, H.T.U., and Neff, G.E., 1956, Channeled scablands of Washington: New data and interpretations: Geological Society of America Bulletin, v.67, no.8, p. 957-1049.

Chow, V.T., Maidment, D.R., and Mays, L.W., 1988, Applied hydrology: New York, McGraw-Hill Book Company, 572 p.

Conley, J.C., "Blue Lake to be lowered in attack on weeds, algae": Oregonian, 22 september, 1981.

Craig, H., 1961, Isotopic variations in meteoric waters: Science, v. 133, p. 1702-1703.

Darling, W.G., Allen, D.J., and Armannson, H., 1990, Indirect detection of subsurface outflow from a rift valley lake: Journal of Hydrology, v.113, p. 297-306.

Davis, J.C., 1986, Statistics and data analysis in geology (2nd edition): New York, John Wiley \& Sons, $646 \mathrm{p}$.

Domennico, P.A., and Schwartz, F.W., 1990, Physical and chemical hydrogeology: New York, John wiley \& Sons, 824 p.

Driscoll, F.G., 1986, Groundwater and wells (2nd edition): St. Paul, Minnesota, Johnson Division, 1089 p.

Fetter, C.W., 1988, Applied hydrogeology (2nd edition): Columbus, Ohio, Merrill Publishing Company, 592 p.

Foxworthy, B.L., Hogenson, G.M., and Hampton, E.R., 1964, Records of wells and springs, water levels, and chemical quality of ground water in the East Portland area, Oregon: Oregon Ground-Water Report 3, 79 p., 1 pl.

Griffin, W.C., Watkins, F.A., Jr., and Swenson, H.A., 1956, Water resources of the Portland, Oregon, and Vancouver, Washington area: U.S. Geological Survey Circular 372, 45 p., 2 pls. 
Hartford, S.V., and McFarland, W.D., 1989, Lithology, thickness, and extent of hydrogeologic units underlying the East Portland area, oregon: U.S. Geological Survey water-Resources Investigations Report 88-4110, 23 p., 6 pls.

Heath, R.C., 1982, Basic ground-water hydrology: U.S. Geological Survey Water-supply Paper 2220, 84 p.

Hoffstetter, W.F., 1981, Blue Lake aquifer development potential study: Prepared for Portland Water Bureau (unpublished).

1984, Geology of the Portland well field: oregon Geology, v. 46 , no. 6 , p. 63-67.

Hogenson, G.M., and Foxworthy, B.L., 1965, Ground water in the east Portland area Oregon: U.S. Geological Survey Water Supply Paper 1793, 78 p.

Krabbenhoft, D.P., Bowser, C.J., Anderson, M.P. and Valley, J.W., 1990, Estimating groundwater exchange with lakes 1. The stable isotope mass balance method: Water Resources Research, v. 26, no. 10, p. 2445-2453.

Krabbenhoft, D.P., Anderson, M.P., and Bowser, C.J., 1990, Estimating groundwater exchange with lakes 2 . Calibration of a three-dimensional, solute transport model to a stable isotope plume: Water Resources Research, v. 26, no. 10 , p. 2455-2462.

Leighton, J., 1990, Effects of Blue Lake aquifer pumping on groundwater levels, March 1990: Prepared for Portland water Bureau (unpublished).

Malin, R., 1989, Summary report east Multnomah County hydrogeologic study: Prepared for oregon Department of Environmental Quality (unpublished).

McCarthy, K.A., and Anderson, D.B., 1990, Ground-water data for the Portland Basin, oregon and Washington: U.S. Geological Survey open-File Report 90-126, 56 p.

Mundorff, M.J., 1964, Geology and ground-water conditions of clark county, washington, with a description of a major alluvial aquifer along the Columbia River: U.S. Geological Survey Water-Supply Paper 1600, 268 p., 3 pl. 
Stichler, W., and Moser, H. 1979, An example of exchange between lake and groundwater. In: Isotopes in lake studies: Proceeding of the Advisory Group Meeting, International Atomic Energy Agency, Vienna, 1977. p.115-119.

Swanson, R.D., 1986, A stratigraphic and geochemical study of the Troutdale Formation and Sandy River mudstone in the Portland Basin and lower Columbia River Gorge: M.S. thesis (unpublished), Portland State University, Portland, Oregon, $151 \mathrm{p}$.

Swanson, R.D., McFarland, W.D., Gonthier, J.B. and Wilkinson, J.M., in press, A description of hydrogeologic units in the Portland Basin, Oregon and Washington: U.S. Geological Survey Water-Resources Investigations Report 90-4196.

Trimble, D.E., 1963, Geology of Portland, Oregon and adjacent areas: U.S. Geological Survey Bulletin 1119, $1119 \mathrm{p}$.

Willis, R.F., 1978, Pilot well study: Bureau of Water Works, Portland, Oregon, 150 p. 23 pls. 
APPENDIX A

WELL IDENTIFICATION CROSS REFERENCE 
WELL

WELL

ID

1

2

3

4

5

6

7

8

9

10

11

12

13

14

15

16

17

18

19

20

21

22

23

24

25

26

27

28

29

30

31

32
LOCATION

NUMBER

IN/3E-2lacab2

IN/3E-2 1 acab3

IN/3E-21accd2

IN/3E-2 I accd 3

IN/3E-2 laccd 4

IN/3E-21bdbal

IN/3E-2 1bcbcl

IN/3E-2 ladbc 1

IN / $3 E-21 \mathrm{dbbb} 3$

IN/3E-21dbbb 6

IN/3E-21 cbcdl

IN/3E-2 1acca2

IN/3E-2 1bdba 2

IN/3E-20adbc2

IN/3E-2IbdI

IN/3E-2 lac3

IN/3E-2 lacbb1

IN/3E-2ladbc2

IN/3E-21bcbc2

IN/3E-2ladaal

IN / 3E-ad1

IN/3E-ddC

IN/3E-2lac1

IN/3E-2lacc

IN/3E-2 laddc1

IN/3E-21 dbbb2

IN/3E-21dbbc1

IN/ 3E-2 Idbcc2

IN/3E-21dbccl

IN/3E-21 cbcd2

IN/3E-21dcab

IN/3E-21dd
U.S.G.S.

ID

6269

6269

6267

6267

6267

6271

6272

6266

6268

6268

6273

6270

6264

6245

-

6265

6262

6263

900260

6278

$-$

900192

900261

900268

900269

6274

900271

900266

6277
CITY OF

PORTLAND

ID

$21 \mathrm{ac}(\mathrm{m} 1)$
$21 \mathrm{ac}(\mathrm{m} 1)$
$21 \mathrm{ac}(\mathrm{m} 2)$
$21 \mathrm{ac}(\mathrm{m} 2)$
$21 \mathrm{ac}(\mathrm{m} 2)$

$13 \mathrm{TW}$

$19 \mathrm{TW}$

$18 \mathrm{TW}$

$21 \mathrm{db}(\mathrm{m} 3)$

$21 \mathrm{db}(\mathrm{m} 3)$

$12 \mathrm{PW}$

$13 \mathrm{PW}$

$14 \mathrm{PW}$

$21 \mathrm{bd}$ (p2)

21 ac (p5)

$17 \mathrm{PW}$

$18 \mathrm{PW}$

$19 \mathrm{PW}$

$21 \mathrm{ad}(\mathrm{p} 2)$

$2 \operatorname{lad}(\mathrm{p} 1)$

$21 a c 1$

$21 \mathrm{ac2}$

$21 \mathrm{ad}$ (p3)

$21 \mathrm{db}$ (p1)

$21 \mathrm{db}(\mathrm{p} 2)$
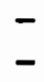

-

$-$

$21 d d$ 
APPENDIX B

HYDROLOGIC AND METEOROLOGIC DATA 
RIVER STAGE, WATER LEVELS, AND BAROMETRIC PRESSURE FOR FEBRUARY, 1991

$\begin{array}{ccc}\text { JULIAN } & \text { TIME } & \text { COLUMBIA } \\ \text { DAY } & \text { (MINUTES STAGE } \\ & \text { (METERS) }\end{array}$

$\begin{array}{ccc}\text { WELL 6 } & \text { WELL } 9 & \text { BAROMETRIC } \\ \text { WATER LEVEL } & \text { WATER LEVEL } & \text { PRESSURE } \\ \text { (METERS) } & \text { (METERS) } & \text { (CENTIMETERS) }\end{array}$

\begin{tabular}{|c|c|c|c|c|c|}
\hline 32 & 30 & 3.813 & 3.011 & 2.731 & 75.954 \\
\hline 32 & 60 & 3.807 & 3.011 & 2.733 & 75.905 \\
\hline 32 & 90 & 3.801 & 3.011 & 2.734 & 75.900 \\
\hline 32 & 120 & 3.792 & 3.011 & 2.736 & 75.895 \\
\hline 32 & 150 & 3.786 & 3.011 & 2.739 & 75.888 \\
\hline 32 & 180 & 3.773 & 3.005 & 2.739 & 75.870 \\
\hline 32 & 210 & 3.716 & 2.999 & 2.739 & 75.857 \\
\hline 32 & 240 & 3.661 & 2.990 & 2.739 & 75.819 \\
\hline 32 & 270 & 3.627 & 2.978 & 2.739 & 75.791 \\
\hline 32 & 300 & 3.594 & 2.969 & 2.739 & 75.773 \\
\hline 32 & 330 & 3.566 & 2.960 & 2.739 & 75.766 \\
\hline 32 & 360 & 3.551 & 2.957 & 2.739 & 75.761 \\
\hline 32 & 390 & 3.536 & 2.950 & 2.739 & 75.761 \\
\hline 32 & 420 & 3.533 & 2.947 & 2.739 & 75.766 \\
\hline 32 & 450 & 3.533 & 2.947 & 2.736 & 75.753 \\
\hline 32 & 480 & 3.539 & 2.947 & 2.734 & 75.740 \\
\hline 32 & 510 & 3.545 & 2.947 & 2.728 & 75.745 \\
\hline 32 & 540 & 3.545 & 2.947 & 2.728 & 75.705 \\
\hline 32 & 570 & 3.603 & 2.947 & 2.725 & 75.659 \\
\hline 32 & 600 & 3.630 & 2.947 & 2.722 & 75.644 \\
\hline 32 & 630 & 3.652 & 2.947 & 2.716 & 75.568 \\
\hline 32 & 660 & 3.667 & 2.954 & 2.716 & 75.537 \\
\hline 32 & 690 & 3.679 & 2.960 & 2.716 & 75.486 \\
\hline 32 & 720 & 3.700 & 2.960 & 2.716 & 75.461 \\
\hline 32 & 750 & 3.709 & 2.963 & 2.716 & 75.420 \\
\hline 32 & 780 & 3.719 & 2.963 & 2.716 & 75.408 \\
\hline 32 & 810 & 3.725 & 2.966 & 2.717 & 75.382 \\
\hline 32 & 840 & 3.728 & 2.966 & 2.717 & 75.382 \\
\hline 32 & 870 & 3.737 & 2.966 & 2.717 & 75.331 \\
\hline 32 & 900 & 3.737 & 2.966 & 2.717 & 75.288 \\
\hline 32 & 930 & 3.737 & 2.966 & 2.717 & 75.265 \\
\hline 32 & 960 & 3.737 & 2.963 & 2.717 & 75.263 \\
\hline 32 & 990 & 3.737 & 2.963 & 2.717 & 75.242 \\
\hline 32 & 1020 & 3.740 & 2.963 & 2.717 & 75.222 \\
\hline 32 & 1050 & 3.752 & 2.963 & 2.717 & 75.258 \\
\hline 32 & 1080 & 3.770 & 2.978 & 2.717 & 75.268 \\
\hline 32 & 1110 & 3.795 & 2.984 & 2.722 & 75.319 \\
\hline 32 & 1140 & 3.816 & 2.990 & 2.722 & 75.301 \\
\hline 32 & 1170 & 3.837 & 3.008 & 2.722 & 75.278 \\
\hline 32 & 1200 & 3.862 & 3.014 & 2.722 & 75.230 \\
\hline 32 & 1230 & 3.883 & 3.030 & 2.725 & 75.225 \\
\hline 32 & 1260 & 3.904 & 3.042 & 2.733 & 75.199 \\
\hline 32 & 1290 & 3.926 & 3.057 & 2.746 & 75.199 \\
\hline 32 & 1320 & 3.938 & 3.066 & 2.752 & 75.220 \\
\hline 32 & 1350 & 3.944 & 3.075 & 2.761 & 75.214 \\
\hline 32 & 1380 & 3.956 & 3.075 & 2.761 & 75.194 \\
\hline 32 & 1410 & 3.953 & 3.082 & 2.766 & 75.202 \\
\hline 32 & 1440 & 3.950 & 3.082 & 2.774 & 75.181 \\
\hline 33 & 30 & 3.944 & 3.088 & 2.783 & 75.181 \\
\hline 33 & 60 & 3.935 & 3.088 & 2.783 & 75.187 \\
\hline 33 & 90 & 3.901 & 3.088 & 2.783 & 75.225 \\
\hline 33 & 120 & 3.874 & 3.088 & 2.786 & 75.255 \\
\hline 33 & 150 & 3.856 & 3.085 & 2.789 & 75.278 \\
\hline 33 & 180 & 3.840 & 3.066 & 2.789 & 75.298 \\
\hline 33 & 210 & 3.822 & 3.060 & 2.789 & 75.306 \\
\hline 33 & 240 & 3.798 & 3.048 & 2.789 & 75.314 \\
\hline 33 & 270 & 3.755 & 3.039 & 2.789 & 75.321 \\
\hline 33 & 300 & 3.722 & 3.027 & 2.783 & 75.324 \\
\hline 33 & 330 & 3.697 & 3.024 & 2.783 & 75.334 \\
\hline 33 & 360 & 3.679 & 3.018 & 2.777 & 75.367 \\
\hline 33 & 390 & 3.670 & 3.011 & 2.774 & 75.397 \\
\hline 33 & 420 & 3.664 & 3.008 & 2.768 & 75.451 \\
\hline 33 & 450 & 3.664 & 3.008 & 2.768 & 75.486 \\
\hline 33 & 480 & 3.673 & 3.008 & 2.757 & 75.522 \\
\hline 33 & 510 & 3.679 & 3.008 & 2.755 & 75.565 \\
\hline 33 & 540 & 3.685 & 3.011 & 2.754 & 75.606 \\
\hline 33 & 570 & 3.697 & 3.011 & 2.754 & 75.654 \\
\hline 33 & 600 & 3.709 & 3.011 & 2.751 & 75.662 \\
\hline
\end{tabular}




\begin{tabular}{|c|c|c|c|c|c|}
\hline 33 & 630 & 3.709 & 3.011 & 2.748 & 75.667 \\
\hline 33 & 660 & 3.709 & 3.011 & 2.749 & 75.674 \\
\hline 33 & 690 & 3.706 & 3.011 & 2.748 & 75.677 \\
\hline 33 & 720 & 3.700 & 3.011 & 2.748 & 75.684 \\
\hline 33 & 750 & 3.685 & 3.011 & 2.748 & 75.695 \\
\hline 33 & 780 & 3.673 & 3.005 & 2.748 & 75.712 \\
\hline 33 & 810 & 3.658 & 2.999 & 2.748 & 75.758 \\
\hline 33 & 840 & 3.639 & 2.990 & 2.746 & 75.783 \\
\hline 33 & 870 & 3.624 & 2.981 & 2.746 & 75.814 \\
\hline 33 & 900 & 3.609 & 2.969 & 2.742 & 75.860 \\
\hline 33 & 930 & 3.587 & 2.957 & 2.733 & 75.903 \\
\hline 33 & 960 & 3.575 & 2.947 & 2.729 & 75.941 \\
\hline 33 & 990 & 3.560 & 2.932 & 2.723 & 75.951 \\
\hline 33 & 1020 & 3.548 & 2.923 & 2.701 & 75.971 \\
\hline 33 & 1050 & 3.548 & 2.911 & 2.690 & 76.002 \\
\hline 33 & 1080 & 3.548 & 2.908 & 2.687 & 76.025 \\
\hline 33 & 1110 & 3.548 & 2.908 & 2.684 & 76.045 \\
\hline 33 & 1140 & 3.557 & 2.908 & 2.679 & 76.083 \\
\hline 33 & 1170 & 3.572 & 2.908 & 2.679 & 76.098 \\
\hline 33 & 1200 & 3.587 & 2.908 & 2.676 & 76.116 \\
\hline 33 & 1230 & 3.609 & 2.914 & 2.676 & 76.142 \\
\hline 33 & 1260 & 3.627 & 2.923 & 2.676 & 76.162 \\
\hline 33 & 1290 & 3.639 & 2.932 & 2.676 & 76.192 \\
\hline 33 & 1320 & 3.648 & 2.935 & 2.676 & 76.210 \\
\hline 33 & 1350 & 3.655 & 2.938 & 2.676 & 76.220 \\
\hline 33 & 1380 & 3.655 & 2.938 & 2.676 & 76.248 \\
\hline 33 & 1410 & 3.658 & 2.938 & 2.676 & 76.251 \\
\hline 33 & 1440 & 3.658 & 2.938 & 2.676 & 76.248 \\
\hline 34 & 30 & 3.658 & 2.938 & 2.676 & 76.251 \\
\hline 34 & 60 & 3.658 & 2.938 & 2.676 & 76.258 \\
\hline 34 & 90 & 3.652 & 2.938 & 2.676 & 76.261 \\
\hline 34 & 120 & 3.645 & 2.938 & 2.676 & 76.276 \\
\hline 34 & 150 & 3.636 & 2.935 & 2.676 & 76.294 \\
\hline 34 & 180 & 3.624 & 2.929 & 2.676 & 76.271 \\
\hline 34 & 210 & 3.615 & 2.926 & 2.676 & 76.266 \\
\hline 34 & 240 & 3.603 & 2.917 & 2.676 & 76.263 \\
\hline 34 & 270 & 3.587 & 2.911 & 2.676 & 76.256 \\
\hline 34 & 300 & 3.581 & 2.908 & 2.676 & 76.251 \\
\hline 34 & 330 & 3.572 & 2.905 & 2.676 & 76.256 \\
\hline 34 & 360 & 3.566 & 2.905 & 2.676 & 76.246 \\
\hline 34 & 390 & 3.563 & 2.902 & 2.676 & 76.238 \\
\hline 34 & 420 & 3.557 & 2.899 & 2.676 & 76.233 \\
\hline 34 & 450 & 3.545 & 2.899 & 2.676 & 76.220 \\
\hline 34 & 480 & 3.542 & 2.899 & 2.676 & 76.203 \\
\hline 34 & 510 & 3.542 & 2.905 & 2.676 & 76.208 \\
\hline 34 & 540 & 3.557 & 2.917 & 2.676 & 76.218 \\
\hline 34 & 570 & 3.566 & 2.926 & 2.676 & 76.236 \\
\hline 34 & 600 & 3.569 & 2.929 & 2.676 & 76.241 \\
\hline 34 & 630 & 3.578 & 2.932 & 2.676 & 76.243 \\
\hline 34 & 660 & 3.581 & 2.932 & 2.676 & 76.241 \\
\hline 34 & 690 & 3.581 & 2.932 & 2.676 & 76.241 \\
\hline 34 & 720 & 3.581 & 2.932 & 2.676 & 76.261 \\
\hline 34 & 750 & 3.569 & 2.935 & 2.676 & 76.297 \\
\hline 34 & 780 & 3.560 & 2.935 & 2.676 & 76.314 \\
\hline 34 & 810 & 3.545 & 2.932 & 2.676 & 76.332 \\
\hline 34 & 840 & 3.530 & 2.923 & 2.676 & 76.345 \\
\hline 34 & 870 & 3.511 & 2.914 & 2.676 & 76.363 \\
\hline 34 & 900 & 3.496 & 2.905 & 2.676 & 76.383 \\
\hline 34 & 930 & 3.481 & 2.899 & 2.676 & 76.391 \\
\hline 34 & 960 & 3.459 & 2.886 & 2.667 & 76.406 \\
\hline 34 & 990 & 3.459 & 2.880 & 2.661 & 76.424 \\
\hline 34 & 1020 & 3.459 & 2.877 & 2.656 & 76.429 \\
\hline 34 & 1050 & 3.463 & 2.862 & 2.650 & 76.472 \\
\hline 34 & 1080 & 3.466 & 2.856 & 2.641 & 76.484 \\
\hline 34 & 1110 & 3.472 & 2.853 & 2.641 & 76.482 \\
\hline 34 & 1140 & 3.475 & 2.844 & 2.635 & 76.464 \\
\hline 34 & 1170 & 3.478 & 2.844 & 2.629 & 76.449 \\
\hline 34 & 1200 & 3.481 & 2.844 & 2.629 & 76.439 \\
\hline 34 & 1230 & 3.484 & 2.844 & 2.629 & 76.431 \\
\hline 34 & 1260 & 3.490 & 2.853 & 2.629 & 76.426 \\
\hline 34 & 1290 & 3.493 & 2.856 & 2.629 & 76.426 \\
\hline 34 & 1320 & 3.496 & 2.862 & 2.629 & 76.429 \\
\hline 34 & 1350 & 3.499 & 2.868 & 2.629 & 76.418 \\
\hline 34 & 1380 & 3.502 & 2.868 & 2.629 & 76.373 \\
\hline 34 & 1410 & 3.508 & 2.874 & 2.629 & 76.335 \\
\hline 34 & 1440 & 3.511 & 2.877 & 2.629 & 76.317 \\
\hline 35 & 30 & 3.514 & 2.880 & 2.629 & 76.261 \\
\hline
\end{tabular}




\begin{tabular}{|c|c|c|c|c|c|}
\hline 35 & 60 & 3.511 & 2.880 & 2.629 & 76.203 \\
\hline 35 & 90 & 3.511 & 2.880 & 2.630 & 76.167 \\
\hline 35 & 120 & 3.505 & 2.880 & 2.630 & 76.116 \\
\hline 35 & 150 & 3.456 & 2.880 & 2.630 & 76.058 \\
\hline 35 & 180 & 3.429 & 2.880 & 2.635 & 76.002 \\
\hline 35 & 210 & 3.405 & 2.880 & 2.641 & 75.949 \\
\hline 35 & 240 & 3.377 & 2.877 & 2.644 & 75.910 \\
\hline 35 & 270 & 3.310 & 2.865 & 2.644 & 75.898 \\
\hline 35 & 300 & 3.264 & 2.856 & 2.644 & 75.890 \\
\hline 35 & 330 & 3.252 & 2.844 & 2.644 & 75.883 \\
\hline 35 & 360 & 3.228 & 2.833 & 2.644 & 75.855 \\
\hline 35 & 390 & 3.213 & 2.818 & 2.641 & 75.837 \\
\hline 35 & 420 & 3.197 & 2.812 & 2.638 & 75.816 \\
\hline 35 & 450 & 3.158 & 2.806 & 2.635 & 75.844 \\
\hline 35 & 480 & 3.149 & 2.798 & 2.621 & 75.910 \\
\hline 35 & 510 & 3.133 & 2.792 & 2.609 & 75.946 \\
\hline 35 & 540 & 3. 136 & 2.787 & 2.597 & 75.989 \\
\hline 35 & 570 & 3.136 & 2.787 & 2.597 & 76.012 \\
\hline 35 & 600 & 3.149 & 2.787 & 2.588 & 76.010 \\
\hline 35 & 630 & 3.170 & 2.787 & 2.588 & 76.027 \\
\hline 35 & 660 & 3.179 & 2.787 & 2.586 & 76.032 \\
\hline 35 & 690 & 3.200 & 2.787 & 2.586 & 76.027 \\
\hline 35 & 720 & 3.228 & 2.787 & 2.586 & 76.030 \\
\hline 35 & 750 & 3.252 & 2.787 & 2.583 & 76.048 \\
\hline 35 & 780 & 3.258 & 2.787 & 2.583 & 76.063 \\
\hline 35 & 810 & 3.271 & 2.787 & 2.583 & 76.063 \\
\hline 35 & 840 & 3.295 & 2.787 & 2.583 & 76.043 \\
\hline 35 & 870 & 3.313 & 2.787 & 2.583 & 76.022 \\
\hline 35 & 900 & 3.313 & 2.787 & 2.583 & 76.020 \\
\hline 35 & 930 & 3.322 & 2.787 & 2.583 & 76.025 \\
\hline 35 & 960 & 3.322 & 2.781 & 2.576 & 76.040 \\
\hline 35 & 990 & 3.322 & 2.777 & 2.574 & 76.048 \\
\hline 35 & 1020 & 3.322 & 2.774 & 2.574 & 76.048 \\
\hline 35 & 1050 & 3.322 & 2.771 & 2.574 & 76.050 \\
\hline 35 & 1080 & 3.322 & 2.766 & 2.568 & 76.050 \\
\hline 35 & 1110 & 3.319 & 2.765 & 2.566 & 76.048 \\
\hline 35 & 1140 & 3.319 & 2.761 & 2.566 & 76.045 \\
\hline 35 & 1170 & 3.319 & 2.761 & 2.562 & 76.045 \\
\hline 35 & 1200 & 3.319 & 2.760 & 2.559 & 76.050 \\
\hline 35 & 1230 & 3.322 & 2.760 & 2.556 & 76.058 \\
\hline 35 & 1260 & 3.335 & 2.760 & 2.556 & 76.096 \\
\hline 35 & 1290 & 3.374 & 2.760 & 2.553 & 76.103 \\
\hline 35 & 1320 & 3.399 & 2.760 & 2.553 & 76.109 \\
\hline 35 & 1350 & 3.417 & 2.769 & 2.553 & 76.121 \\
\hline 35 & 1380 & 3.438 & 2.775 & 2.553 & 76.149 \\
\hline 35 & 1410 & 3.459 & 2.781 & 2. 553 & 76.185 \\
\hline 35 & 1440 & 3.472 & 2.789 & 2.553 & 76.225 \\
\hline 36 & 30 & 3.459 & 2.789 & 2.553 & 76.271 \\
\hline 36 & 60 & 3.444 & 2.789 & 2.553 & 76.330 \\
\hline 36 & 90 & 3.420 & 2.789 & 2.553 & 76.378 \\
\hline 36 & 120 & 3.408 & 2.789 & 2.553 & 76.441 \\
\hline 36 & 150 & 3.392 & 2.786 & 2.553 & 76.515 \\
\hline 36 & 180 & 3.374 & 2.781 & 2.537 & 76.586 \\
\hline 36 & 210 & 3.356 & 2.774 & 2.530 & 76.637 \\
\hline 36 & 240 & 3.341 & 2.765 & 2.530 & 76.680 \\
\hline 36 & 270 & 3.328 & 2.758 & 2.524 & 76.741 \\
\hline 36 & 300 & 3.313 & 2.754 & 2.518 & 76.782 \\
\hline 36 & 330 & 3.301 & 2.746 & 2.515 & 76.825 \\
\hline 36 & 360 & 3.289 & 2.737 & 2.515 & 76.901 \\
\hline 36 & 390 & 3.274 & 2.733 & 2.505 & 76.947 \\
\hline 36 & 420 & 3.267 & 2.729 & 2.504 & 76.975 \\
\hline 36 & 450 & 3.264 & 2.728 & 2.504 & 76.990 \\
\hline 36 & 480 & 3.264 & 2.728 & 2.504 & 77.018 \\
\hline 36 & 510 & 3.271 & 2.728 & 2.504 & 77.033 \\
\hline 36 & 540 & 3.286 & 2.728 & 2.504 & 77.089 \\
\hline 36 & 570 & 3.310 & 2.734 & 2.504 & 77.102 \\
\hline 36 & 600 & 3.325 & 2.746 & 2.504 & 77.132 \\
\hline 36 & 630 & 3.386 & 2.758 & 2.504 & 77.147 \\
\hline 36 & 660 & 3.426 & 2.763 & 2.504 & 77.175 \\
\hline 36 & 690 & 3.469 & 2.778 & 2.504 & 77.201 \\
\hline 36 & 720 & 3.502 & 2.793 & 2.502 & 77.201 \\
\hline 36 & 750 & 3.527 & 2.810 & 2.507 & 77.170 \\
\hline 36 & 780 & 3.551 & 2.816 & 2. 515 & 77.147 \\
\hline 36 & 810 & 3.566 & 2.830 & 2.525 & 77.122 \\
\hline 36 & 840 & 3.581 & 2.838 & 2.537 & 77.099 \\
\hline 36 & 870 & 3.591 & 2.841 & 2.545 & 77.081 \\
\hline 36 & 900 & 3.597 & 2.847 & 2.551 & 77.081 \\
\hline
\end{tabular}




\begin{tabular}{|c|c|c|c|c|c|}
\hline $\begin{array}{l}36 \\
36\end{array}$ & $\begin{array}{l}930 \\
960\end{array}$ & $\begin{array}{l}3.600 \\
3.606\end{array}$ & $\begin{array}{l}2.850 \\
2.853\end{array}$ & $\begin{array}{l}2.554 \\
2.563\end{array}$ & $\begin{array}{l}77.086 \\
77.084\end{array}$ \\
\hline 36 & 990 & 3.608 & 2.859 & 2.569 & 77.074 \\
\hline 36 & 1020 & 3.609 & 2.865 & 2.574 & 77.059 \\
\hline 36 & 1050 & 3.609 & 2.865 & 2.580 & 77.031 \\
\hline 36 & 1080 & 3.609 & 2.868 & 2.583 & 77.015 \\
\hline 36 & 1110 & 3.606 & 2.871 & 2.588 & 76.972 \\
\hline 36 & 1140 & 3.606 & 2.871 & 2.589 & 76.962 \\
\hline 36 & 1170 & 3.606 & 2.871 & 2.592 & 76.959 \\
\hline 36 & 1200 & 3.606 & 2.871 & 2.595 & 76.970 \\
\hline 36 & 1230 & 3.606 & 2.871 & 2.595 & 76.980 \\
\hline 36 & 1260 & 3.606 & 2.871 & 2.597 & 76.959 \\
\hline 36 & 1290 & 3.609 & 2.880 & 2.600 & 76.934 \\
\hline 36 & 1320 & 3.624 & 2.883 & 2.608 & 76.911 \\
\hline 36 & 1350 & 3.642 & 2.896 & 2.611 & 76.898 \\
\hline 36 & 1380 & 3.658 & 2.902 & 2.614 & 76.888 \\
\hline 36 & 1410 & 3.667 & 2.908 & 2.618 & 76.896 \\
\hline 36 & 1440 & 3.673 & 2.908 & 2.618 & 76.896 \\
\hline 37 & 30 & 3.679 & 2.917 & 2.623 & 76.886 \\
\hline 37 & 60 & 3.685 & 2.920 & 2.630 & 76.876 \\
\hline 37 & 90 & 3.670 & 2.926 & 2.635 & 76.840 \\
\hline 37 & 120 & 3.648 & 2.929 & 2.644 & 76.779 \\
\hline 37 & 150 & 3.633 & 2.935 & 2.653 & 76.733 \\
\hline 37 & 180 & 3.630 & 2.941 & 2.658 & 76.718 \\
\hline 37 & 210 & 3.612 & 2.941 & 2.658 & 76.733 \\
\hline 37 & 240 & 3.594 & 2.938 & 2.658 & 76.744 \\
\hline 37 & 270 & 3.575 & 2.938 & 2.658 & 76.711 \\
\hline 37 & 300 & 3.569 & 2.938 & 2.661 & 76.688 \\
\hline 37 & 330 & 3.560 & 2.932 & 2.661 & 76.675 \\
\hline 37 & 360 & 3.548 & 2.926 & 2.661 & 76.672 \\
\hline 37 & 390 & 3.536 & 2.923 & 2.661 & 76.680 \\
\hline 37 & 420 & 3.523 & 2.917 & 2.661 & 76.685 \\
\hline 37 & 450 & 3.530 & 2.908 & 2.661 & 76.723 \\
\hline 37 & 480 & 3.551 & 2.908 & 2.661 & 76.731 \\
\hline 37 & 510 & 3.563 & 2.908 & 2.661 & 76.736 \\
\hline 37 & 540 & 3.575 & 2.908 & 2.661 & 76.731 \\
\hline 37 & 570 & 3.597 & 2.914 & 2.661 & 76.726 \\
\hline 37 & 600 & 3.615 & 2.920 & 2.661 & 76.690 \\
\hline 37 & 630 & 3.633 & 2.932 & 2.661 & 76.670 \\
\hline 37 & 660 & 3.639 & 2.941 & 2.661 & 76.660 \\
\hline 37 & 690 & 3.655 & 2.947 & 2.662 & 76.629 \\
\hline 37 & 720 & 3.655 & 2.957 & 2.667 & 76.589 \\
\hline 37 & 750 & 3.664 & 2.960 & 2.675 & 76.578 \\
\hline 37 & 780 & 3.673 & 2.969 & 2.679 & 76.556 \\
\hline 37 & 810 & 3.682 & 2.975 & 2.685 & 76.533 \\
\hline 37 & 840 & 3.682 & 2.978 & 2.690 & 76.523 \\
\hline 37 & 870 & 3.682 & 2.978 & 2.691 & 76.512 \\
\hline 37 & 900 & 3.682 & 2.978 & 2.694 & 76.479 \\
\hline 37 & 930 & 3.679 & 2.984 & 2.697 & 76.472 \\
\hline 37 & 960 & 3.679 & 2.981 & 2.697 & 76.469 \\
\hline 37 & 990 & 3.673 & 2.981 & 2.697 & 76.469 \\
\hline 37 & 1020 & 3.658 & 2.981 & 2.697 & 76.477 \\
\hline 37 & 1050 & 3.655 & 2.978 & 2.697 & 76.490 \\
\hline 37 & 1080 & 3.648 & 2.972 & 2.697 & 76.500 \\
\hline 37 & 1110 & 3.648 & 2.966 & 2.697 & 76.497 \\
\hline 37 & 1140 & 3.648 & 2.966 & 2.697 & 76.492 \\
\hline 37 & 1170 & 3.648 & 2.966 & 2.697 & 76.484 \\
\hline 37 & 1200 & 3.645 & 2.963 & 2.697 & 76.482 \\
\hline 37 & 1230 & 3.636 & 2.963 & 2.697 & 76.487 \\
\hline 37 & 1260 & 3.624 & 2.957 & 2.697 & 76.487 \\
\hline 37 & 1290 & 3.615 & 2.954 & 2.697 & 76.490 \\
\hline 37 & 1320 & 3.606 & 2.947 & 2.697 & 76.502 \\
\hline 37 & 1350 & 3.606 & 2.947 & 2.697 & 76.510 \\
\hline 37 & 1380 & 3.600 & 2.944 & 2.694 & 76.517 \\
\hline 37 & 1410 & 3.594 & 2.938 & 2.693 & 76.540 \\
\hline 37 & 1440 & 3.581 & 2.938 & 2.691 & 76.553 \\
\hline 38 & 30 & 3.575 & 2.938 & 2.690 & 76.558 \\
\hline 38 & 60 & 3.575 & 2.935 & 2.690 & 76.561 \\
\hline 38 & 90 & 3.575 & 2.935 & 2.685 & 76.578 \\
\hline 38 & 120 & 3.575 & 2.929 & 2.682 & 76.591 \\
\hline 38 & 150 & 3.575 & 2.929 & 2.679 & 76.594 \\
\hline 38 & 180 & 3.575 & 2.926 & 2.679 & 76.578 \\
\hline 38 & 210 & 3.575 & 2.926 & 2.679 & 76.578 \\
\hline 38 & 240 & 3.575 & 2.923 & 2.679 & 76.584 \\
\hline 38 & 270 & 3.536 & 2.920 & 2.676 & 76.584 \\
\hline 38 & 300 & 3.499 & 2.917 & 2.676 & 76.566 \\
\hline 38 & 330 & 3.499 & 2.908 & 2.676 & 76.561 \\
\hline
\end{tabular}




\begin{tabular}{|c|c|c|c|c|c|}
\hline $\begin{array}{l}38 \\
38\end{array}$ & $\begin{array}{l}360 \\
390\end{array}$ & $\begin{array}{l}3.499 \\
3.499\end{array}$ & $\begin{array}{l}2.899 \\
2.893\end{array}$ & $\begin{array}{l}2.676 \\
2.667\end{array}$ & $\begin{array}{l}76.566 \\
76.561\end{array}$ \\
\hline 38 & 420 & 3.499 & 2.883 & 2.661 & 76.558 \\
\hline 38 & 450 & 3.499 & 2.877 & 2.658 & 76.571 \\
\hline 38 & 480 & 3.499 & 2.871 & 2.653 & 76.576 \\
\hline 38 & 510 & 3.499 & 2.865 & 2.649 & 76.586 \\
\hline 38 & 540 & 3.499 & 2.859 & 2.644 & 76.622 \\
\hline 38 & 570 & 3.499 & 2.859 & 2.640 & 76.639 \\
\hline 38 & 600 & 3.499 & 2.859 & 2.638 & 76.647 \\
\hline 38 & 630 & 3.499 & 2.859 & 2.635 & 76.657 \\
\hline 38 & 660 & 3.499 & 2.859 & 2.630 & 76.665 \\
\hline 38 & 690 & 3.499 & 2.862 & 2.630 & 76.660 \\
\hline 38 & 720 & 3.499 & 2.871 & 2.630 & 76.624 \\
\hline 38 & 750 & 3.499 & 2.883 & 2.630 & 76.589 \\
\hline 38 & 780 & 3.499 & 2.890 & 2.630 & 76.576 \\
\hline 38 & 810 & 3.499 & 2.896 & 2.630 & 76.561 \\
\hline 38 & 840 & 3.499 & 2.896 & 2.629 & 76.540 \\
\hline 38 & 870 & 3.499 & 2.902 & 2.630 & 76.538 \\
\hline 38 & 900 & 3.499 & 2.902 & 2.630 & 76.535 \\
\hline 38 & 930 & 3.499 & 2.902 & 2.630 & 76.535 \\
\hline 38 & 960 & 3.502 & 2.902 & 2.630 & 76.530 \\
\hline 38 & 990 & 3.502 & 2.902 & 2.632 & 76.525 \\
\hline 38 & 1020 & 3.502 & 2.902 & 2.632 & 76.523 \\
\hline 38 & 1050 & 3.502 & 2.902 & 2.632 & 76.523 \\
\hline 38 & 1080 & 3.502 & 2.902 & 2.632 & 76.528 \\
\hline 38 & 1110 & 3.502 & 2.902 & 2.632 & 76.538 \\
\hline 38 & 1140 & 3.502 & 2.902 & 2.632 & 76.533 \\
\hline 38 & 1170 & 3.502 & 2.899 & 2.633 & 76.535 \\
\hline 38 & 1200 & 3.502 & 2.896 & 2.632 & 76.540 \\
\hline 38 & 1230 & 3.502 & 2.890 & 2.632 & 76.545 \\
\hline 38 & 1260 & 3.502 & 2.883 & 2.632 & 76.545 \\
\hline 38 & 1290 & 3.502 & 2.880 & 2.632 & 76.551 \\
\hline 38 & 1320 & 3.502 & 2.877 & 2.632 & 76.551 \\
\hline 38 & 1350 & 3.502 & 2.871 & 2.632 & 76.553 \\
\hline 38 & 1380 & 3.502 & 2.868 & 2.632 & 76.553 \\
\hline 38 & 1410 & 3.502 & 2.862 & 2.633 & 76.548 \\
\hline 38 & 1440 & 3.502 & 2.862 & 2.630 & 76.548 \\
\hline 39 & 30 & 3.502 & 2.859 & 2.630 & 76.540 \\
\hline 39 & 60 & 3.502 & 2.859 & 2.627 & 76.545 \\
\hline 39 & 90 & 3.496 & 2.856 & 2.626 & 76.558 \\
\hline 39 & 120 & 3.493 & 2.853 & 2.621 & 75.563 \\
\hline 39 & 150 & 3.453 & 2.850 & 2.618 & 76.558 \\
\hline 39 & 180 & 3.432 & 2.844 & 2.617 & 76.558 \\
\hline 39 & 210 & 3.417 & 2.841 & 2.617 & 76.548 \\
\hline 39 & 240 & 3.405 & 2.833 & 2.614 & 76.545 \\
\hline 39 & 270 & 3.383 & 2.827 & 2.611 & 76.540 \\
\hline 39 & 300 & 3.371 & 2.821 & 2.611 & 76.530 \\
\hline 39 & 330 & 3,362 & 2.815 & 2.609 & 76.525 \\
\hline 39 & 360 & 3.350 & 2.807 & 2.597 & 76.523 \\
\hline 39 & 390 & 3.341 & 2.801 & 2.595 & 76.525 \\
\hline 39 & 420 & 3.335 & 2.795 & 2.592 & 76.530 \\
\hline 39 & 450 & 3.325 & 2.787 & 2.580 & 76.543 \\
\hline 39 & 480 & 3.325 & 2.778 & 2.574 & 76.548 \\
\hline 39 & 510 & 3.347 & 2.775 & 2.573 & 76.548 \\
\hline 39 & 540 & 3.356 & 2.771 & 2.568 & 76.553 \\
\hline 39 & 570 & 3.368 & 2.768 & 2.562 & 76.540 \\
\hline 39 & 600 & 3.374 & 2.768 & 2.562 & 76.533 \\
\hline 39 & 630 & 3.386 & 2.768 & 2.557 & 76.528 \\
\hline 39 & 660 & 3.399 & 2.768 & 2.557 & 76.545 \\
\hline 39 & 690 & 3.408 & 2.768 & 2.556 & 76.525 \\
\hline 39 & 720 & 3.420 & 2.768 & 2.556 & 76.510 \\
\hline 39 & 750 & 3.447 & 2.769 & 2.556 & 76.482 \\
\hline 39 & 780 & 3.472 & 2.780 & 2.556 & 76.454 \\
\hline 39 & 810 & 3.487 & 2.792 & 2.556 & 76.436 \\
\hline 39 & 840 & 3.502 & 2.795 & 2.554 & 76.431 \\
\hline 39 & 870 & 3.520 & 2.800 & 2.554 & 76.431 \\
\hline 39 & 900 & 3.530 & 2.801 & 2.554 & 76.439 \\
\hline 39 & 930 & 3.551 & 2.803 & 2.554 & 76.446 \\
\hline 39 & 960 & 3.566 & 2.806 & 2.554 & 76.449 \\
\hline 39 & 990 & 3.581 & 2.809 & 2.554 & 76.454 \\
\hline 39 & 1020 & 3.591 & 2.812 & 2.554 & 76.459 \\
\hline 39 & 1050 & 3.600 & 2.815 & 2.554 & 76.464 \\
\hline 39 & 1080 & 3.609 & 2.815 & 2.554 & 76.467 \\
\hline 39 & 1110 & 3.618 & 2.819 & 2.554 & 76.474 \\
\hline 39 & 1140 & 3.630 & 2.818 & 2.554 & 76.477 \\
\hline 39 & 1170 & 3.636 & 2.824 & 2.554 & 76.482 \\
\hline 39 & 1200 & 3.642 & 2.824 & 2.554 & 76.490 \\
\hline
\end{tabular}




\begin{tabular}{|c|c|c|c|c|c|}
\hline 39 & 1230 & 3.642 & 2.824 & 2.554 & 76.497 \\
\hline 39 & 1260 & 3.636 & 2.824 & 2.554 & 76.545 \\
\hline 39 & 1290 & 3.627 & 2.824 & 2.554 & 76.571 \\
\hline 39 & 1320 & 3.615 & 2.824 & 2.554 & 76.586 \\
\hline 39 & 1350 & 3.606 & 2.824 & 2.554 & 76.589 \\
\hline 39 & 1380 & 3.600 & 2.821 & 2.556 & 76.589 \\
\hline 39 & 1410 & 3.575 & 2.821 & 2.556 & 76.596 \\
\hline 39 & 1440 & 3.560 & 2.818 & 2.556 & 76.609 \\
\hline 40 & 30 & 3.542 & 2.812 & 2.556 & 76.604 \\
\hline 40 & 60 & 3.527 & 2.809 & 2.556 & 76.584 \\
\hline 40 & 90 & 3.514 & 2.809 & 2.556 & 76.568 \\
\hline 40 & 120 & 3.508 & 2.809 & 2.556 & 76.556 \\
\hline 40 & 150 & 3.505 & 2.809 & 2.556 & 76.556 \\
\hline 40 & 180 & 3.496 & 2.809 & 2.556 & 76.540 \\
\hline 40 & 210 & 3.484 & 2.809 & 2.556 & 76.525 \\
\hline 40 & 240 & 3.466 & 2.806 & 2.556 & 76.530 \\
\hline 40 & 270 & 3.417 & 2.801 & 2.556 & 76.553 \\
\hline 40 & 300 & 3.380 & 2.793 & 2.556 & 76.573 \\
\hline 40 & 330 & 3.353 & 2.783 & 2.556 & 76.599 \\
\hline 40 & 360 & 3.331 & 2.771 & 2.551 & 76.614 \\
\hline 40 & 390 & 3.307 & 2.761 & 2.544 & 76.617 \\
\hline 40 & 420 & 3.289 & 2.755 & 2.542 & 76.606 \\
\hline 40 & 450 & 3.280 & 2.749 & 2.542 & 76.558 \\
\hline 40 & 480 & 3.274 & 2.746 & 2.542 & 76.553 \\
\hline 40 & 510 & 3.258 & 2.740 & 2.542 & 76.553 \\
\hline 40 & 540 & 3.252 & 2.729 & 2.528 & 76.553 \\
\hline 40 & 570 & 3.240 & 2.720 & 2.524 & 76.551 \\
\hline 40 & 600 & 3.225 & 2.710 & 2.519 & 76.545 \\
\hline 40 & 630 & 3.222 & 2.704 & 2.513 & 76.543 \\
\hline 40 & 660 & 3.222 & 2.697 & 2.509 & 76.543 \\
\hline 40 & 690 & 3.228 & 2.696 & 2.505 & 76.505 \\
\hline 40 & 720 & 3.240 & 2.696 & 2.504 & 76.472 \\
\hline 40 & 750 & 3.249 & 2.696 & 2.505 & 76.449 \\
\hline 40 & 780 & 3.261 & 2.696 & 2.505 & 76.424 \\
\hline 40 & 810 & 3.258 & 2.684 & 2.493 & 76.406 \\
\hline 40 & 840 & 3.246 & 2.685 & 2.493 & 76.391 \\
\hline 40 & 870 & 3.228 & 2.685 & 2.492 & 76.385 \\
\hline 40 & 900 & 3.222 & 2.684 & 2.492 & 76.378 \\
\hline 40 & 930 & 3.203 & 2.685 & 2.487 & 76.378 \\
\hline 40 & 960 & 3.188 & 2.684 & 2.487 & 76.370 \\
\hline 40 & 990 & 3.179 & 2.684 & 2.483 & 76.360 \\
\hline 40 & 1020 & 3.173 & 2.679 & 2.481 & 76.357 \\
\hline 40 & 1050 & 3.155 & 2.673 & 2.473 & 76.355 \\
\hline 40 & 1080 & 3.142 & 2.665 & 2.472 & 76.350 \\
\hline 40 & 1110 & 3.158 & 2.658 & 2.463 & 76.350 \\
\hline 40 & 1140 & 3.173 & 2.650 & 2.458 & 76.380 \\
\hline 40 & 1170 & 3.179 & 2.643 & 2.451 & 76.396 \\
\hline 40 & 1200 & 3.179 & 2.633 & 2.441 & 76.411 \\
\hline 40 & 1230 & 3.179 & 2.629 & 2.434 & 76.411 \\
\hline 40 & 1260 & 3.176 & 2.621 & 2.432 & 76.418 \\
\hline 40 & 1290 & 3.167 & 2.612 & 2.426 & 76.421 \\
\hline 40 & 1320 & 3.152 & 2.606 & 2.416 & 76.426 \\
\hline 40 & 1350 & 3.136 & 2.597 & 2.412 & 76.434 \\
\hline 40 & 1380 & 3.115 & 2.589 & 2.412 & 76.431 \\
\hline 40 & 1410 & 3.100 & 2.582 & 2.402 & 76.418 \\
\hline 40 & 1440 & 3.088 & 2.576 & 2.399 & 76.406 \\
\hline 41 & 30 & 3.069 & 2.566 & 2.394 & 76.396 \\
\hline 41 & 60 & 3.060 & 2.556 & 2.385 & 76.388 \\
\hline 41 & 90 & 3.051 & 2.554 & 2.377 & 76.385 \\
\hline 41 & 120 & 3.042 & 2.547 & 2.367 & 76.391 \\
\hline 41 & 150 & 3.039 & 2.542 & 2.364 & 76.401 \\
\hline 41 & 180 & 3.039 & 2.536 & 2.364 & 76.403 \\
\hline 41 & 210 & 3.039 & 2.533 & 2.356 & 76.408 \\
\hline 41 & 240 & 3.039 & 2.531 & 2.350 & 76.411 \\
\hline 41 & 270 & 3.039 & 2.525 & 2.344 & 76.411 \\
\hline 41 & 300 & 3.039 & 2.524 & 2.338 & 76.393 \\
\hline 41 & 330 & 3.042 & 2.524 & 2.338 & 76.385 \\
\hline 41 & 360 & 3.048 & 2.524 & 2.338 & 76.378 \\
\hline 41 & 390 & 3.085 & 2.524 & 2,338 & 76.380 \\
\hline 41 & 420 & 3.109 & 2.524 & 2.335 & 76.368 \\
\hline 41 & 450 & 3.124 & 2.524 & 2.333 & 76.363 \\
\hline 41 & 480 & 3.139 & 2.524 & 2.329 & 76.360 \\
\hline 41 & 510 & 3.152 & 2.524 & 2.326 & 76.365 \\
\hline 41 & 540 & 3.173 & 2.524 & 2.323 & 76.363 \\
\hline 41 & 570 & 3.185 & 2.524 & 2.323 & 76.352 \\
\hline 41 & 600 & 3.188 & 2.524 & 2.323 & 76.342 \\
\hline 41 & 630 & 3.194 & 2.524 & 2.323 & 76.340 \\
\hline
\end{tabular}




\begin{tabular}{|c|c|c|c|c|c|}
\hline $\begin{array}{l}41 \\
41\end{array}$ & $\begin{array}{l}660 \\
690\end{array}$ & $\begin{array}{l}3.194 \\
3.197\end{array}$ & $\begin{array}{l}2.524 \\
2.524\end{array}$ & $\begin{array}{l}2.318 \\
2.318\end{array}$ & $\begin{array}{l}76.312 \\
76.286\end{array}$ \\
\hline 41 & 720 & 3.197 & 2.524 & 2.316 & 76.256 \\
\hline 41 & 750 & 3. 194 & 2.528 & 2.316 & 76.241 \\
\hline 41 & 780 & 3. 194 & 2.536 & 2.316 & 76.213 \\
\hline 41 & 810 & 3.203 & 2.541 & 2.316 & 76.175 \\
\hline 41 & 840 & 3.210 & 2.547 & 2.316 & 76.164 \\
\hline 41 & 870 & 3.228 & 2.559 & 2.316 & 76.162 \\
\hline 41 & 900 & 3.237 & 2.562 & 2.316 & 76.142 \\
\hline 41 & 930 & 3.243 & 2.569 & 2.316 & 76.134 \\
\hline 41 & 960 & 3.252 & 2.576 & 2.316 & 76.144 \\
\hline 41 & 990 & 3.264 & 2.580 & 2.321 & 76.147 \\
\hline 41 & 1020 & 3.274 & 2.585 & 2.321 & 76.144 \\
\hline 41 & 1050 & 3.271 & 2.585 & 2.321 & 76.144 \\
\hline 41 & 1080 & 3.200 & 2.585 & 2.321 & 76.144 \\
\hline 41 & 1110 & 3.222 & 2.585 & 2.321 & 76.144 \\
\hline 41 & 1140 & 3.228 & 2.585 & 2.321 & 76.149 \\
\hline 41 & 1170 & 3.231 & 2.585 & 2.321 & 76.152 \\
\hline 41 & 1200 & 3.231 & 2.585 & 2.321 & 76.154 \\
\hline 41 & 1230 & 3.231 & 2.580 & 2.321 & 76.159 \\
\hline 41 & 1260 & 3.228 & 2.576 & 2.321 & 76.159 \\
\hline 41 & 1290 & 3.228 & 2.573 & 2.321 & 76.144 \\
\hline 41 & 1320 & 3.225 & 2.569 & 2.321 & 76.134 \\
\hline 41 & 1350 & 3.216 & 2.566 & 2. 321 & 76.131 \\
\hline 41 & 1380 & 3.213 & 2.559 & 2.321 & 76.134 \\
\hline 41 & 1410 & 3.206 & 2.554 & 2.321 & 76.131 \\
\hline 41 & 1440 & 3.200 & 2.550 & 2.323 & 76.124 \\
\hline 42 & 30 & 3.191 & 2.547 & 2.321 & 76.111 \\
\hline 42 & 60 & 3.188 & 2.542 & 2.321 & 76.076 \\
\hline 42 & 90 & 3.182 & 2.539 & 2.323 & 76.043 \\
\hline 42 & 120 & 3.182 & 2.531 & 2.323 & 76.045 \\
\hline 42 & 150 & 3.200 & 2.531 & 2.323 & 76.040 \\
\hline 42 & 180 & 3.213 & 2.530 & 2.323 & 76.010 \\
\hline 42 & 210 & 3.228 & 2.531 & 2.323 & 75.992 \\
\hline 42 & 240 & 3.246 & 2.534 & 2.323 & 76.010 \\
\hline 42 & 270 & 3.267 & 2.539 & 2.318 & 76.012 \\
\hline 42 & 300 & 3.280 & 2.544 & 2.318 & 75.999 \\
\hline 42 & 330 & 3.301 & 2.557 & 2.318 & 75.969 \\
\hline 42 & 360 & 3.325 & 2.560 & 2.318 & 76.002 \\
\hline 42 & 390 & 3.350 & 2.560 & 2.318 & 76.027 \\
\hline 42 & 420 & 3.359 & 2.565 & 2.318 & 76.065 \\
\hline 42 & 450 & 3.365 & 2.565 & 2.315 & 76.111 \\
\hline 42 & 480 & 3.368 & 2.574 & 2.315 & 76.106 \\
\hline 42 & 510 & 3. 377 & 2.579 & 2.315 & 76.109 \\
\hline 42 & 540 & 3.395 & 2.579 & 2.315 & 76.091 \\
\hline 42 & 570 & 3.399 & 2.583 & 2.315 & 76.093 \\
\hline 42 & 600 & 3.405 & 2.586 & 2.323 & 76.095 \\
\hline 42 & 630 & 3.411 & 2.586 & 2.323 & 76.103 \\
\hline 42 & 660 & 3.414 & 2.588 & 2.323 & 76.098 \\
\hline 42 & 690 & 3.417 & 2.588 & 2.323 & 76.093 \\
\hline 42 & 720 & 3.414 & 2.594 & 2.326 & 76.083 \\
\hline 42 & 750 & 3.408 & 2.594 & 2.329 & 76.073 \\
\hline 42 & 780 & 3.414 & 2.594 & 2.330 & 76.043 \\
\hline 42 & 810 & 3.420 & 2.603 & 2.335 & 76.022 \\
\hline 42 & 840 & 3.426 & 2.614 & 2.339 & 76.007 \\
\hline 42 & 870 & 3.441 & 2.621 & 2.344 & 75.997 \\
\hline 42 & 900 & 3.456 & 2.637 & 2.348 & 75.997 \\
\hline 42 & 930 & 3.478 & 2.649 & 2.353 & 75.994 \\
\hline 42 & 960 & 3.502 & 2.665 & 2.362 & 76.002 \\
\hline 42 & 990 & 3.514 & 2.675 & 2.365 & 76.012 \\
\hline 42 & 1020 & 3.539 & 2.682 & 2.371 & 76.022 \\
\hline 42 & 1050 & 3.557 & 2.688 & 2.374 & 76.048 \\
\hline 42 & 1080 & 3.563 & 2.696 & 2.380 & 76.060 \\
\hline 42 & 1110 & 3.575 & 2.701 & 2.384 & 76.088 \\
\hline 42 & 1140 & 3.581 & 2.707 & 2.387 & 76.114 \\
\hline 42 & 1170 & 3.609 & 2.711 & 2.391 & 76.142 \\
\hline 42 & 1200 & 3.630 & 2.716 & 2.393 & 76.167 \\
\hline 42 & 1230 & 3.648 & 2.720 & 2.400 & 76.190 \\
\hline 42 & 1260 & 3.664 & 2.725 & 2.403 & 76.203 \\
\hline 42 & 1290 & 3.676 & 2.725 & 2.408 & 76.233 \\
\hline 42 & 1320 & 3.676 & 2.733 & 2.411 & 76.253 \\
\hline 42 & 1350 & 3.667 & 2.733 & 2.414 & 76.266 \\
\hline 42 & 1380 & 3.655 & 2.733 & 2.419 & 76.297 \\
\hline 42 & 1410 & 3.645 & 2.733 & 2.420 & 76.312 \\
\hline 42 & 1440 & 3.636 & 2.733 & 2.423 & 76.317 \\
\hline 43 & 30 & 3.597 & 2.733 & 2.426 & 76.317 \\
\hline 43 & 60 & 3.578 & 2.733 & 2.432 & 76.317 \\
\hline
\end{tabular}




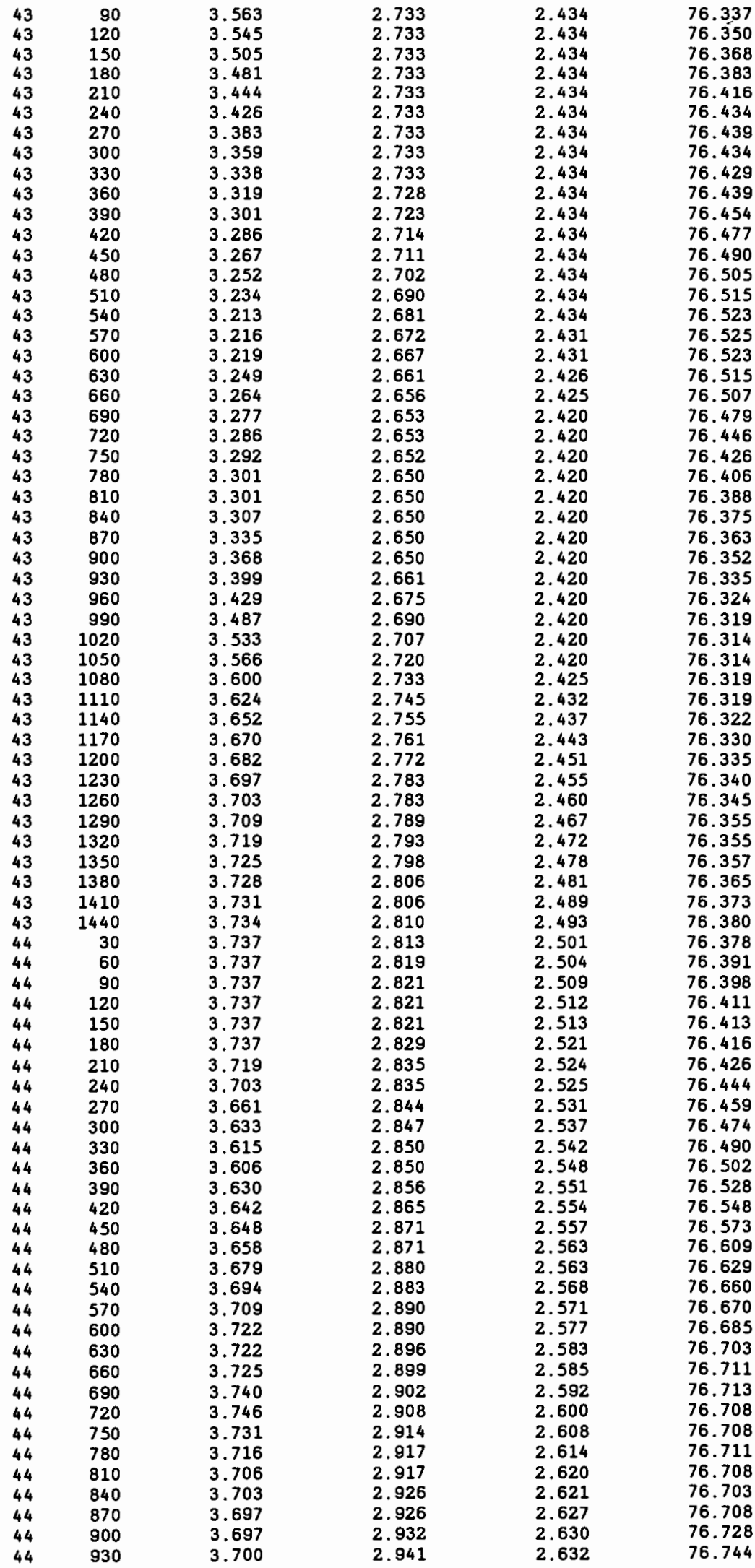




\begin{tabular}{|c|c|c|c|c|c|}
\hline 44 & $\begin{array}{l}960 \\
990\end{array}$ & 3.712 & 2.950 & 2.638 & 76.756 \\
\hline $\begin{array}{l}44 \\
44\end{array}$ & 1020 & $\begin{array}{l}3.728 \\
3.746\end{array}$ & $\begin{array}{l}2.969 \\
2.981\end{array}$ & $\begin{array}{l}2.644 \\
2.653\end{array}$ & $\begin{array}{l}76.761 \\
76.766\end{array}$ \\
\hline 44 & 1050 & 3.764 & 2.996 & 2.662 & 76.777 \\
\hline 44 & 1080 & 3.786 & 3.008 & 2.672 & 76.805 \\
\hline 44 & 1120 & 3.828 & 3.024 & 2.678 & 76.807 \\
\hline 44 & 1140 & 3.862 & 3.033 & 2.690 & 76.802 \\
\hline 44 & 1170 & 3.883 & 3.051 & 2.704 & 76.799 \\
\hline 44 & 1200 & 3.895 & 3.066 & 2.717 & 76.805 \\
\hline 44 & 1230 & 3.904 & 3.078 & 2.726 & 76.810 \\
\hline 44 & 1260 & 3.911 & 3.085 & 2.737 & 76.807 \\
\hline 44 & 1290 & 3.911 & 3.091 & 2.748 & 76.799 \\
\hline 44 & 1320 & 3.895 & 3.097 & 2.755 & 76.787 \\
\hline 44 & 1350 & 3.883 & 3.097 & 2.765 & 76.777 \\
\hline 44 & 1380 & 3.874 & 3.103 & 2.774 & 76.789 \\
\hline 44 & 1410 & 3.868 & 3.103 & 2.780 & 76.802 \\
\hline 44 & 1440 & 3.862 & 3.103 & 2.780 & 76.787 \\
\hline 45 & 30 & 3.859 & 3.103 & 2.789 & 76.761 \\
\hline 45 & 60 & 3.847 & 3.103 & 2.801 & 76.741 \\
\hline 45 & 90 & 3.844 & 3.103 & 2.804 & 76.726 \\
\hline 45 & 120 & 3.844 & 3.109 & 2.807 & 76.718 \\
\hline 45 & 150 & 3.844 & 3.106 & 2.807 & 76.703 \\
\hline 45 & 180 & 3.844 & 3.106 & 2.813 & 76.657 \\
\hline 45 & 210 & 3.847 & 3.106 & 2.816 & 76.632 \\
\hline 45 & 240 & 3.859 & 3.115 & 2.822 & 76.624 \\
\hline 45 & 270 & 3.868 & 3.121 & 2.829 & 76.591 \\
\hline 45 & 300 & 3.883 & 3.130 & 2.835 & 76.558 \\
\hline 45 & 330 & 3.904 & 3.139 & 2.847 & 76.510 \\
\hline 45 & 360 & 3.929 & 3.155 & 2.853 & 76.477 \\
\hline 45 & 390 & 3.953 & 3.167 & 2.862 & 76.457 \\
\hline 45 & 420 & 3.978 & 3.179 & 2.874 & 76.449 \\
\hline 45 & 450 & 3.987 & 3.188 & 2.880 & 76.441 \\
\hline 45 & 480 & 4.002 & 3.197 & 2.883 & 76.441 \\
\hline 45 & 510 & 4.002 & 3.203 & 2.886 & 76.436 \\
\hline 45 & 540 & 4.005 & 3.210 & 2.893 & 76.434 \\
\hline 45 & 570 & 4.026 & 3.213 & 2.899 & 76.441 \\
\hline 45 & 600 & 4.042 & 3.219 & 2.902 & 76.454 \\
\hline 45 & 630 & 4.048 & 3.219 & 2.905 & 76.454 \\
\hline 45 & 660 & 4.051 & 3.225 & 2.905 & 76.429 \\
\hline 45 & 690 & 4.054 & 3.231 & 2.917 & 76.383 \\
\hline 45 & 720 & 4.057 & 3.240 & 2.923 & 76.375 \\
\hline 45 & 750 & 4.057 & 3.246 & 2. 935 & 76.363 \\
\hline 45 & 780 & 4.060 & 3.249 & 2.938 & 76.324 \\
\hline 45 & 810 & 4.060 & 3.252 & 2.941 & 76.309 \\
\hline 45 & 840 & 4.057 & 3.258 & 2.947 & 76.309 \\
\hline 45 & 870 & 4.036 & 3.258 & 2.950 & 76.299 \\
\hline 45 & 900 & 4.020 & 3.258 & 2.950 & 76.294 \\
\hline 45 & 930 & 4.011 & 3.258 & 2.954 & 76.289 \\
\hline 45 & 960 & 4.005 & 3.258 & 2.960 & 76.302 \\
\hline 45 & 990 & 4.005 & 3.261 & 2.960 & 76.289 \\
\hline 45 & 1020 & 4.005 & 3.264 & 2.960 & 76.274 \\
\hline 45 & 1050 & 4.005 & 3.274 & 2.963 & 76.294 \\
\hline 45 & 1080 & 4.008 & 3.283 & 2.969 & 76.312 \\
\hline 45 & 1110 & 4.029 & 3.286 & 2.969 & 76.314 \\
\hline 45 & 1140 & 4.042 & 3.292 & 2.972 & 76.312 \\
\hline 45 & 1170 & 4.048 & 3.301 & 2.978 & 76.319 \\
\hline 45 & 1200 & 4.048 & 3.301 & 2.984 & 76.312 \\
\hline 45 & 1230 & 4.048 & 3.307 & 2.984 & 76.299 \\
\hline 45 & 1260 & 4.048 & 3.313 & 2.993 & 76.291 \\
\hline 45 & 1290 & 4.048 & 3.313 & 2.996 & 76.289 \\
\hline 45 & 1320 & 4.042 & 3.313 & 2.999 & 76.281 \\
\hline 45 & 1350 & 4.033 & 3.313 & 2.999 & 76.269 \\
\hline 45 & 1380 & 4.026 & 3.313 & 3.005 & 76.266 \\
\hline 45 & 1410 & 4.020 & 3.313 & 3.008 & 76.261 \\
\hline 45 & 1440 & 4.011 & 3.313 & 3.008 & 76.253 \\
\hline 46 & 30 & 3.996 & 3.313 & 3.008 & 76.248 \\
\hline 46 & 60 & 3.984 & 3.313 & 3.008 & 76.246 \\
\hline 46 & 90 & 3.965 & 3.313 & 3.008 & 76.236 \\
\hline 46 & 120 & 3.947 & 3.304 & 3.008 & 76.220 \\
\hline 46 & 150 & 3.935 & 3.301 & 3.008 & 76.210 \\
\hline 46 & 180 & 3.920 & 3.295 & 3.008 & 76.208 \\
\hline 46 & 210 & 3.911 & 3.289 & 3.008 & 76.203 \\
\hline 46 & 240 & 3.901 & 3.280 & 3.008 & 76.200 \\
\hline 46 & 270 & 3.892 & 3.277 & 3.008 & 76.200 \\
\hline 46 & 300 & 3.889 & 3.271 & 3.008 & 76.197 \\
\hline 46 & 330 & 3.889 & 3.271 & 3.008 & 76.203 \\
\hline 46 & 360 & 3.889 & 3.271 & 3.008 & 76.205 \\
\hline
\end{tabular}




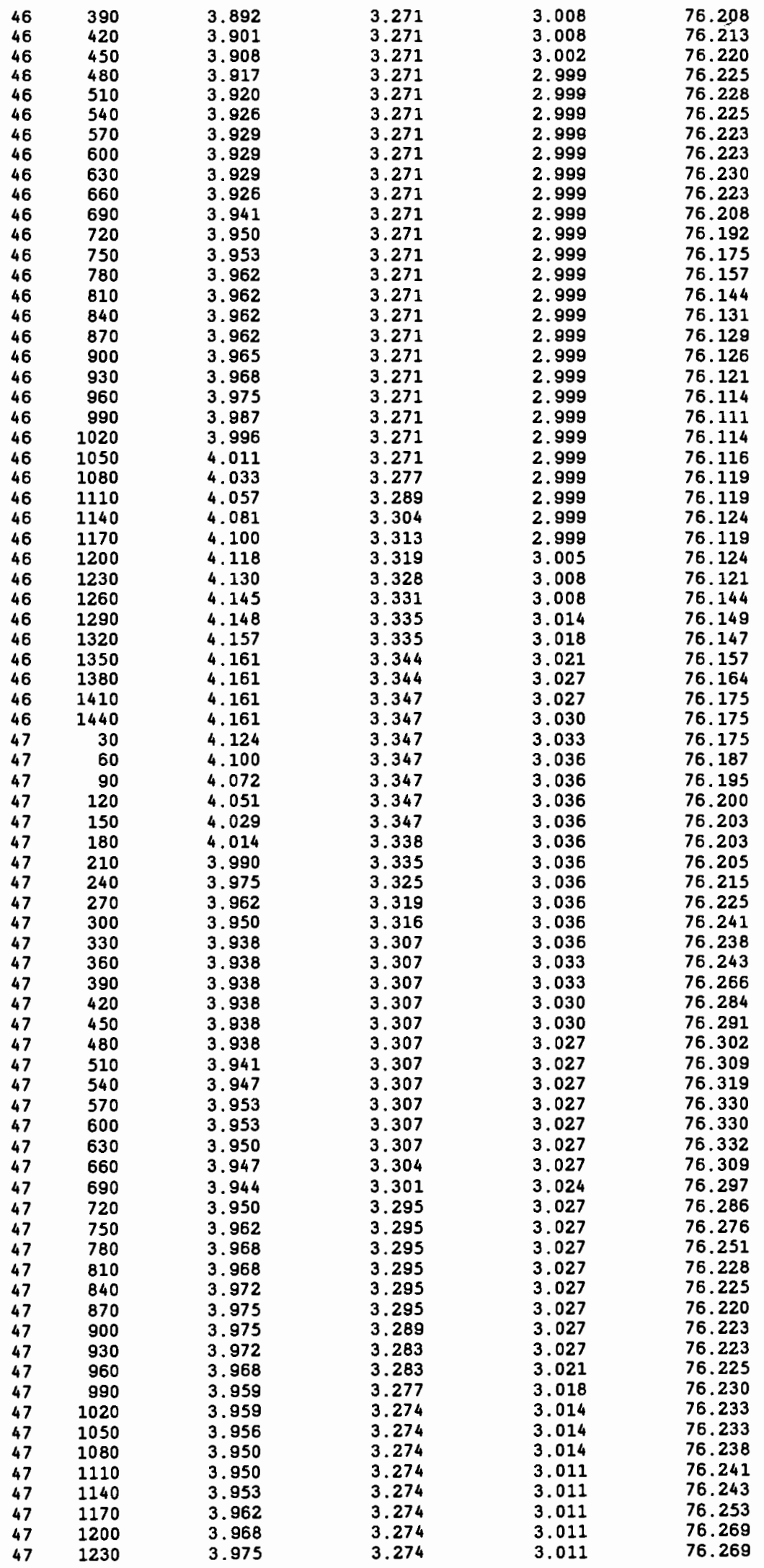




\begin{tabular}{|c|c|c|c|c|c|}
\hline 47 & 1260 & 3.984 & 3.274 & 3.011 & 76.269 \\
\hline 47 & 1290 & 3.984 & 3.274 & 3.011 & 76.263 \\
\hline 47 & 1320 & 3.984 & 3.274 & 3.011 & 76.266 \\
\hline 47 & 1350 & 3.984 & 3.274 & 3.011 & 76.271 \\
\hline 47 & 1380 & 3.981 & 3.274 & 3.011 & 76.291 \\
\hline 47 & 1410 & 3.978 & 3.274 & 3.011 & 76.324 \\
\hline 47 & 1440 & 3.968 & 3.274 & 3.011 & 76.340 \\
\hline 48 & 30 & 3.947 & 3.274 & 3.011 & 76.342 \\
\hline 48 & 60 & 3.929 & 3.274 & 3.005 & 76.363 \\
\hline 48 & 90 & 3.911 & 3.264 & 3.002 & 76.375 \\
\hline 48 & 120 & 3.895 & 3.252 & 2.996 & 76.385 \\
\hline 48 & 150 & 3.880 & 3.249 & 2.990 & 76.401 \\
\hline 48 & 180 & 3.862 & 3.237 & 2.990 & 76.441 \\
\hline 48 & 210 & 3.844 & 3.228 & 2.984 & 76.497 \\
\hline 48 & 240 & 3.828 & 3.219 & 2.975 & 76.517 \\
\hline 48 & 270 & 3.819 & 3.206 & 2.957 & 76.538 \\
\hline 48 & 300 & 3.804 & 3.200 & 2.947 & 76.563 \\
\hline 48 & 330 & 3.795 & 3.188 & 2.941 & 76.586 \\
\hline 48 & 360 & 3.789 & 3.185 & 2.938 & 76.606 \\
\hline 48 & 390 & 3.789 & 3.185 & 2.932 & 76.632 \\
\hline 48 & 420 & 3.789 & 3.185 & 2.929 & 76.660 \\
\hline 48 & 450 & 3.792 & 3.185 & 2.926 & 76.678 \\
\hline 48 & 480 & 3.801 & 3.185 & 2.923 & 76.690 \\
\hline 48 & 510 & 3.810 & 3.185 & 2.923 & 76.711 \\
\hline 48 & 540 & 3.819 & 3.185 & 2.923 & 76.728 \\
\hline 48 & 570 & 3.822 & 3.185 & 2.920 & 76.744 \\
\hline 48 & 600 & 3.825 & 3.185 & 2.920 & 76.764 \\
\hline 48 & 630 & 3.856 & 3.185 & 2.917 & 76.777 \\
\hline 48 & 660 & 3.874 & 3.185 & 2. 917 & 76.784 \\
\hline 48 & 690 & 3.889 & 3.185 & 2.917 & 76.774 \\
\hline 48 & 720 & 3.901 & 3.185 & 2.917 & 76.779 \\
\hline 48 & 750 & 3.908 & 3.185 & 2.917 & 76.782 \\
\hline 48 & 780 & 3.914 & 3.185 & 2.917 & 76.777 \\
\hline 48 & 810 & 3.917 & 3.185 & 2.917 & 76.777 \\
\hline 48 & 840 & 3.917 & 3.185 & 2.917 & 76.779 \\
\hline 48 & 870 & 3.917 & 3.179 & 2.911 & 76.787 \\
\hline 48 & 900 & 3.904 & 3.176 & 2.911 & 76.789 \\
\hline 48 & 930 & 3.895 & 3.176 & 2.911 & 76.794 \\
\hline 48 & 960 & 3.892 & 3.176 & 2.911 & 76.797 \\
\hline 48 & 990 & 3.880 & 3.170 & 2.911 & 76.810 \\
\hline 48 & 1020 & 3.871 & 3.170 & 2.911 & 76.820 \\
\hline 48 & 1050 & 3.865 & 3.164 & 2.911 & 76.843 \\
\hline 48 & 1080 & 3.862 & 3.164 & 2.905 & 76.860 \\
\hline 48 & 1110 & 3.862 & 3.164 & 2.905 & 76.868 \\
\hline 48 & 1140 & 3.862 & 3.164 & 2.902 & 76.881 \\
\hline 48 & 1170 & 3.880 & 3.164 & 2. 902 & 76.898 \\
\hline 48 & 1200 & 3.892 & 3.164 & 2.899 & 76.909 \\
\hline 48 & 1230 & 3.904 & 3.164 & 2.899 & 76.911 \\
\hline 48 & 1260 & 3.917 & 3.170 & 2.899 & 76.919 \\
\hline 48 & 1290 & 3.917 & 3.173 & 2.899 & 76.916 \\
\hline 48 & 1320 & 3.917 & 3.173 & 2.899 & 76.914 \\
\hline 48 & 1350 & 3.914 & 3.179 & 2,899 & 76.914 \\
\hline 48 & 1380 & 3.908 & 3.179 & 2.899 & 76.921 \\
\hline 48 & 1410 & 3.901 & 3.179 & 2.899 & 76.924 \\
\hline 48 & 1440 & 3.895 & 3.179 & 2.899 & 76.934 \\
\hline 49 & 30 & 3.886 & 3.179 & 2.899 & 76.934 \\
\hline 49 & 60 & 3.877 & 3.176 & 2.899 & 76.942 \\
\hline 49 & 90 & 3.856 & 3.170 & 2.899 & 76.947 \\
\hline 49 & 120 & 3.837 & 3.167 & 2.899 & 76.944 \\
\hline 49 & 150 & 3.819 & 3.164 & 2.899 & 76.919 \\
\hline 49 & 180 & 3.801 & 3.158 & 2.899 & 76.919 \\
\hline 49 & 210 & 3.786 & 3.152 & 2.899 & 76.919 \\
\hline 49 & 240 & 3.770 & 3.139 & 2.899 & 76.919 \\
\hline 49 & 270 & 3.752 & 3.136 & 2.896 & 76.914 \\
\hline 49 & 300 & 3.740 & 3.127 & 2.896 & 76.906 \\
\hline 49 & 330 & 3.728 & 3.121 & 2.890 & 76.896 \\
\hline 49 & 350 & 3.722 & 3.118 & 2.890 & 76.886 \\
\hline 49 & 390 & 3.719 & 3.115 & 2.883 & 76.876 \\
\hline 49 & 420 & 3.719 & 3.115 & 2.883 & 76.868 \\
\hline 49 & 450 & 3.719 & 3.115 & 2,880 & 76.863 \\
\hline 49 & 480 & 3.728 & 3.115 & 2.880 & 76.863 \\
\hline 49 & 510 & 3.740 & 3.115 & 2.874 & 76.865 \\
\hline 49 & 540 & 3.752 & 3.115 & 2.874 & 76.863 \\
\hline 49 & 570 & 3.761 & 3.115 & 2.874 & 76.863 \\
\hline 49 & 600 & 3.770 & 3.118 & 2.874 & 76.865 \\
\hline 49 & 630 & 3.773 & 3.118 & 2.874 & 76.873 \\
\hline 49 & 660 & 3.776 & 3.118 & 2.874 & 76.883 \\
\hline
\end{tabular}




\begin{tabular}{|c|c|c|c|c|c|}
\hline $\begin{array}{l}49 \\
49\end{array}$ & $\begin{array}{l}690 \\
720\end{array}$ & $\begin{array}{l}3.776 \\
3.776\end{array}$ & $\begin{array}{l}3.118 \\
3.118\end{array}$ & $\begin{array}{l}2.874 \\
2.871\end{array}$ & $\begin{array}{l}76.881 \\
76.876\end{array}$ \\
\hline 49 & 750 & 3.776 & 3.118 & 2.871 & 76.865 \\
\hline 49 & 780 & 3.776 & 3.118 & 2.871 & 76.855 \\
\hline 49 & 810 & 3.770 & 3.118 & 2.871 & 76.848 \\
\hline 49 & 840 & 3.761 & 3.115 & 2.871 & 76.850 \\
\hline 49 & 870 & 3.752 & 3.109 & 2.868 & 76.845 \\
\hline 49 & 900 & 3.740 & 3.106 & 2.862 & 76.848 \\
\hline 49 & 930 & 3.728 & 3.097 & 2.859 & 76.848 \\
\hline 49 & 960 & 3.719 & 3.091 & 2.856 & 76.850 \\
\hline 49 & 990 & 3.709 & 3.085 & 2.853 & 76.855 \\
\hline 49 & 1020 & 3.697 & 3.072 & 2.847 & 76.863 \\
\hline 49 & 1050 & 3.685 & 3.063 & 2.844 & 76.878 \\
\hline 49 & 1080 & 3.676 & 3.054 & 2.832 & 76.881 \\
\hline 49 & 1110 & 3.670 & 3.051 & 2.825 & 76.886 \\
\hline 49 & 1140 & 3.667 & 3.045 & 2.822 & 76.909 \\
\hline 49 & 1170 & 3.667 & 3.045 & 2.819 & 76.921 \\
\hline 49 & 1200 & 3.667 & 3.045 & 2.819 & 76.926 \\
\hline 49 & 1230 & 3.670 & 3.045 & 2.813 & 76.929 \\
\hline 49 & 1260 & 3.679 & 3.045 & 2.813 & 76.929 \\
\hline 49 & 1290 & 3.682 & 3.045 & 2.813 & 76.934 \\
\hline 49 & 1320 & 3.685 & 3.045 & 2.813 & 76.937 \\
\hline 49 & 1350 & 3.691 & 3.045 & 2.813 & 76.959 \\
\hline 49 & 1380 & 3.691 & 3.045 & 2.807 & 76.957 \\
\hline 49 & 1410 & 3.691 & 3.045 & 2.807 & 76.937 \\
\hline 49 & 1440 & 3.691 & 3.045 & 2. 807 & 76.863 \\
\hline 50 & 30 & 3.691 & 3.045 & 2.807 & 76.835 \\
\hline 50 & 60 & 3.679 & 3.036 & 2.807 & 76.886 \\
\hline 50 & 90 & 3.673 & 3.033 & 2.807 & 76.904 \\
\hline 50 & 120 & 3.661 & 3.030 & 2.807 & 76.914 \\
\hline 50 & 150 & 3.652 & 3.024 & 2.801 & 76.896 \\
\hline 50 & 180 & 3.642 & 3.021 & 2.801 & 76.876 \\
\hline 50 & 210 & 3.633 & 3.014 & 2.801 & 76.838 \\
\hline 50 & 240 & 3.627 & 3,005 & 2.792 & 76.820 \\
\hline 50 & 270 & 3.615 & 2.999 & 2.792 & 76.797 \\
\hline 50 & 300 & 3.609 & 2.993 & 2.786 & 76.792 \\
\hline 50 & 330 & 3.603 & 2.984 & 2.777 & 76.792 \\
\hline 50 & 360 & 3.594 & 2.981 & 2.774 & 76.799 \\
\hline 50 & 390 & 3.594 & 2.981 & 2.761 & 76.807 \\
\hline 50 & 420 & 3.594 & 2.978 & 2.761 & 76.812 \\
\hline 50 & 450 & 3.606 & 2.978 & 2.757 & 76.832 \\
\hline 50 & 480 & 3.621 & 2.978 & 2.754 & 76.840 \\
\hline 50 & 510 & 3.639 & 2.981 & 2.754 & 76.853 \\
\hline 50 & 540 & 3.667 & 2.993 & 2.754 & 76.871 \\
\hline 50 & 570 & 3.679 & 3.002 & 2.754 & 76.888 \\
\hline 50 & 600 & 3.697 & 3.008 & 2.754 & 76.916 \\
\hline 50 & 630 & 3.700 & 3.014 & 2.754 & 76.924 \\
\hline 50 & 660 & 3.706 & 3.018 & 2.754 & 76.934 \\
\hline 50 & 690 & 3.712 & 3.021 & 2.754 & 76.934 \\
\hline 50 & 720 & 3.719 & 3.021 & 2.754 & 76.934 \\
\hline 50 & 750 & 3.722 & 3.021 & 2.754 & 76.924 \\
\hline 50 & 780 & 3.722 & 3.027 & 2.754 & 76.916 \\
\hline 50 & 810 & 3.722 & 3.027 & 2.754 & 76.909 \\
\hline 50 & 840 & 3.722 & 3.027 & 2.754 & 76.893 \\
\hline 50 & 870 & 3.722 & 3.027 & 2.754 & 76.878 \\
\hline 50 & 900 & 3.728 & 3.027 & 2.754 & 76.868 \\
\hline 50 & 930 & 3.728 & 3.027 & 2.754 & 76.865 \\
\hline 50 & 960 & 3.728 & 3.027 & 2.754 & 76.876 \\
\hline 50 & 990 & 3.725 & 3.024 & 2.754 & 76.873 \\
\hline 50 & 1020 & 3.712 & 3.021 & 2.754 & 76.865 \\
\hline 50 & 1050 & 3.706 & 3.014 & 2.754 & 76.865 \\
\hline so & 1080 & 3.706 & 3.011 & 2.754 & 76.863 \\
\hline 50 & 1110 & 3.706 & 3.008 & 2.754 & 76.855 \\
\hline 50 & 1140 & 3.709 & 3.008 & 2.754 & 76.853 \\
\hline 50 & 1170 & 3.709 & 3.005 & 2.754 & 76.825 \\
\hline 50 & 1200 & 3.716 & 3.005 & 2.754 & 76.807 \\
\hline 50 & 1230 & 3.725 & 3.005 & 2.754 & 76.802 \\
\hline 50 & 1260 & 3.737 & 3.011 & 2.754 & 76.799 \\
\hline 50 & 1290 & 3.749 & 3.014 & 2.754 & 76.789 \\
\hline 50 & 1320 & 3.761 & 3.021 & 2.754 & 76.784 \\
\hline 50 & 1350 & 3.773 & 3.021 & 2.754 & 76.784 \\
\hline 50 & 1380 & 3.786 & 3.027 & 2.754 & 76.761 \\
\hline 50 & 1410 & 3.795 & 3.033 & 2.754 & 76.749 \\
\hline 50 & 1440 & 3.804 & 3.033 & 2.754 & 76.746 \\
\hline 51 & 30 & 3.807 & 3.039 & 2.754 & 76.746 \\
\hline 51 & 60 & 3.807 & 3.039 & 2.754 & 76.741 \\
\hline 51 & 90 & 3.804 & 3.039 & 2.754 & 76.754 \\
\hline
\end{tabular}




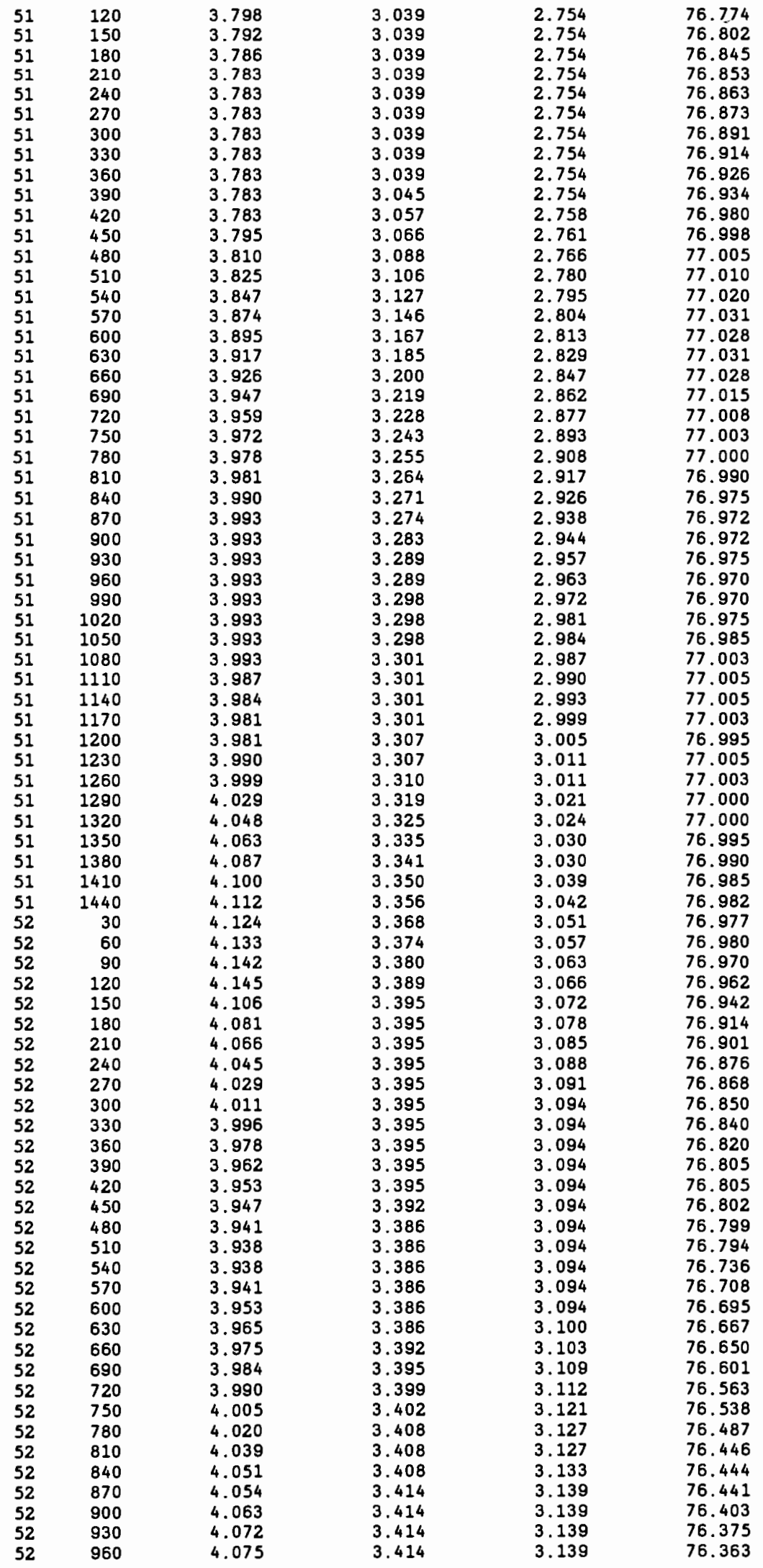




\begin{tabular}{|c|c|c|c|c|c|}
\hline 52 & 990 & 4.081 & 3.414 & 3.142 & 76.340 \\
\hline 52 & 1020 & 4.081 & 3.414 & 3.142 & 76.319 \\
\hline 52 & 1050 & 4.081 & 3.414 & 3.142 & 76.327 \\
\hline 52 & 1080 & 4.081 & 3.414 & 3.142 & 76.337 \\
\hline 52 & 1110 & 4.081 & 3,417 & 3.142 & 76.342 \\
\hline 52 & 1140 & 4.078 & 3.414 & 3.142 & 76.370 \\
\hline 52 & 1170 & 4.078 & 3.417 & 3.142 & 76.380 \\
\hline 52 & 1200 & 4.075 & 3.414 & 3.142 & 76.393 \\
\hline 52 & 1230 & 4.069 & 3.414 & 3.142 & 76.464 \\
\hline 52 & 1260 & 4.066 & 3.405 & 3.139 & 76.477 \\
\hline 52 & 1290 & 4.063 & 3.402 & 3.136 & 76.487 \\
\hline 52 & 1320 & 4.063 & 3.402 & 3.136 & 76.490 \\
\hline 52 & 1350 & 4.042 & 3.402 & 3.136 & 76.487 \\
\hline 52 & 1380 & 4.036 & 3.402 & 3.136 & 76.492 \\
\hline 52 & 1410 & 4.029 & 3.402 & 3.130 & 76.500 \\
\hline 52 & 1440 & 4.020 & 3.395 & 3.127 & 76.525 \\
\hline 53 & 30 & 4.020 & 3.395 & 3.127 & 76.535 \\
\hline 53 & 60 & 4.020 & 3.392 & 3.121 & 76.533 \\
\hline 53 & 90 & 4.039 & 3.392 & 3.121 & 76.548 \\
\hline 53 & 120 & 4.054 & 3.392 & 3.121 & 76.566 \\
\hline 53 & 150 & 4.057 & 3.392 & 3.118 & 76.568 \\
\hline 53 & 180 & 4.063 & 3.392 & 3.118 & 76.566 \\
\hline 53 & 210 & 4.069 & 3.392 & 3.118 & 76.571 \\
\hline 53 & 240 & 4.075 & 3.392 & 3.115 & 76.586 \\
\hline 53 & 270 & 4.075 & 3.392 & 3.115 & 76.632 \\
\hline 53 & 300 & 4.075 & 3.389 & 3.115 & 76.637 \\
\hline 53 & 330 & 4.042 & 3.389 & 3.115 & 76.650 \\
\hline 53 & 360 & 4.017 & 3.383 & 3.115 & 76.672 \\
\hline 53 & 390 & 3.947 & 3.371 & 3.115 & 76.726 \\
\hline 53 & 420 & 3.911 & 3.359 & 3.100 & 76.759 \\
\hline 53 & 450 & 3.831 & 3.344 & 3.091 & 76.779 \\
\hline 53 & 480 & 3.786 & 3.328 & 3.078 & 76.794 \\
\hline 53 & 510 & 3.746 & 3.313 & 3.075 & 76.815 \\
\hline 53 & 540 & 3.709 & 3.301 & 3.069 & 76.835 \\
\hline 53 & 570 & 3.679 & 3.289 & 3.063 & 76.848 \\
\hline 53 & 600 & 3.648 & 3.277 & 3.060 & 76.855 \\
\hline 53 & 630 & 3.630 & 3.267 & 3.054 & 76.860 \\
\hline 53 & 660 & 3.612 & 3.258 & 3.042 & 76.868 \\
\hline 53 & 690 & 3.600 & 3.249 & 3.039 & 76.863 \\
\hline 53 & 720 & 3.584 & 3.240 & 3.033 & 76.848 \\
\hline 53 & 750 & 3.572 & 3.237 & 3.027 & 76.848 \\
\hline 53 & 780 & 3.557 & 3.228 & 3.027 & 76.830 \\
\hline 53 & 810 & 3.539 & 3.222 & 3.021 & 76.827 \\
\hline 53 & 840 & 3.523 & 3.210 & 3.018 & 76.822 \\
\hline 53 & 870 & 3.511 & 3.197 & 3.002 & 76.825 \\
\hline 53 & 900 & 3.496 & 3.185 & 2.999 & 76.825 \\
\hline 53 & 930 & 3.478 & 3.173 & 2.984 & 76.830 \\
\hline 53 & 960 & 3.466 & 3.158 & 2.978 & 76.838 \\
\hline 53 & 990 & 3.484 & 3.146 & 2.966 & 76.845 \\
\hline 53 & 1020 & 3.484 & 3.136 & 2.954 & 76.858 \\
\hline 53 & 1050 & 3.484 & 3.121 & 2.938 & 76.878 \\
\hline 53 & 1080 & 3.472 & 3.109 & 2.932 & 76.886 \\
\hline 53 & 1110 & 3.466 & 3.100 & 2.917 & 76.898 \\
\hline 53 & 1140 & 3.450 & 3.085 & 2.911 & 76.906 \\
\hline 53 & 1170 & 3.487 & 3.069 & 2.902 & 76.914 \\
\hline 53 & 1200 & 3.517 & 3.063 & 2.890 & 76.934 \\
\hline 53 & 1230 & 3.551 & 3.057 & 2.880 & 76.944 \\
\hline 53 & 1260 & 3.581 & 3.054 & 2.874 & 76.952 \\
\hline 53 & 1290 & 3.609 & 3.054 & 2.868 & 76.954 \\
\hline 53 & 1320 & 3.636 & 3.051 & 2.859 & 76.952 \\
\hline 53 & 1350 & 3.670 & 3.051 & 2.859 & 76.944 \\
\hline 53 & 1380 & 3.700 & 3.051 & 2.853 & 76.939 \\
\hline 53 & 1410 & 3.728 & 3.051 & 2.853 & 76.942 \\
\hline 53 & 1440 & 3.755 & 3.051 & 2.853 & 76.962 \\
\hline 54 & 30 & 3.776 & 3.051 & 2.847 & 76.957 \\
\hline 54 & 60 & 3.801 & 3.057 & 2.847 & 76.954 \\
\hline 54 & 90 & 3.828 & 3.066 & 2.847 & 76.954 \\
\hline 54 & 120 & 3.853 & 3.082 & 2.847 & 76.952 \\
\hline 54 & 150 & 3.880 & 3.088 & 2.847 & 76.947 \\
\hline 54 & 180 & 3.901 & 3.097 & 2.847 & 76.957 \\
\hline 54 & 210 & 3.923 & 3.103 & 2.847 & 76.970 \\
\hline 54 & 240 & 3.941 & 3.109 & 2.847 & 76.980 \\
\hline 54 & 270 & 3.965 & 3.115 & 2.847 & 76.990 \\
\hline 54 & 300 & 3.978 & 3.121 & 2.847 & 76.998 \\
\hline 54 & 330 & 3.996 & 3.130 & 2.847 & 77.000 \\
\hline 54 & 360 & 4.011 & 3.142 & 2.847 & 77.005 \\
\hline 54 & 390 & 4.023 & 3.149 & 2.850 & 77.015 \\
\hline
\end{tabular}




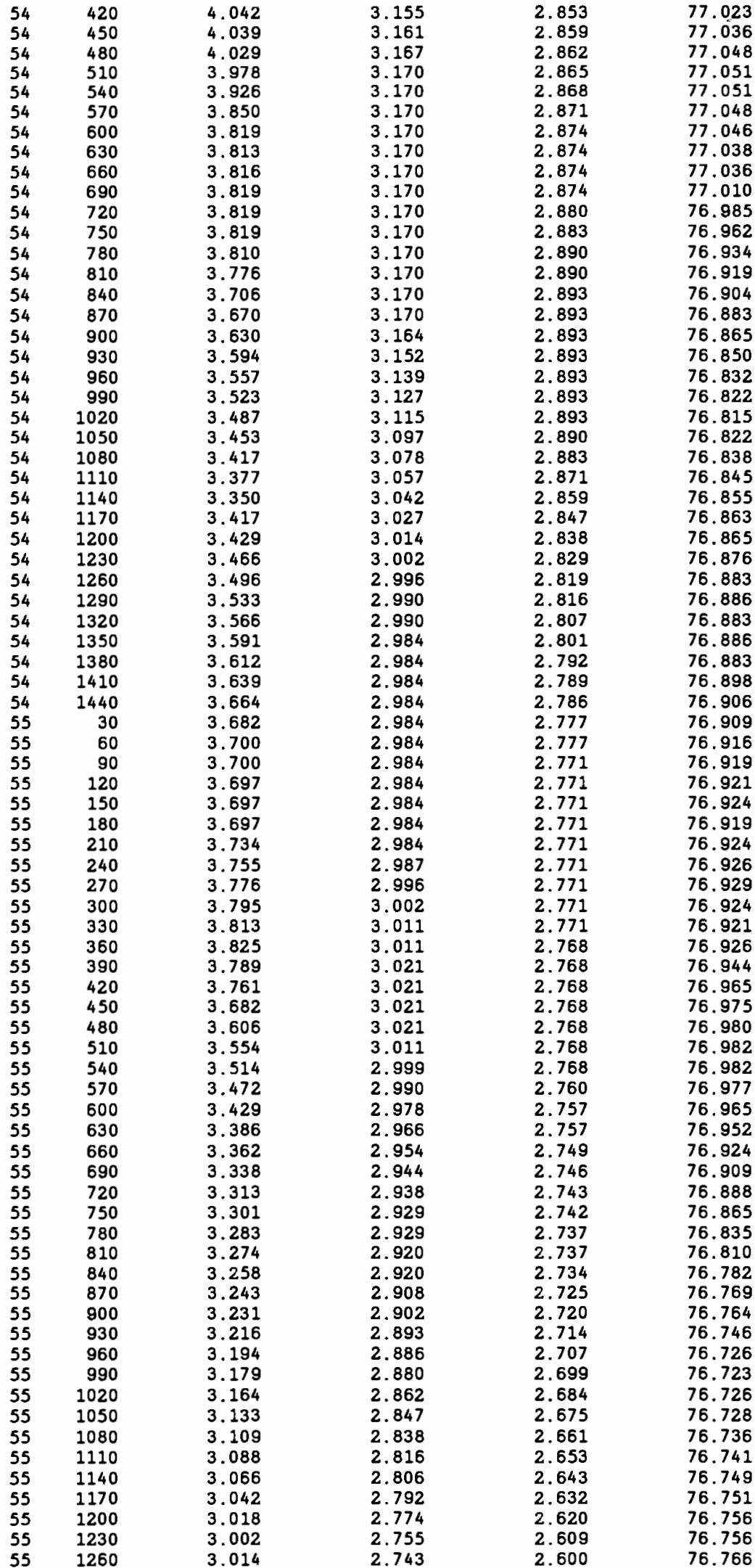




\begin{tabular}{|c|c|c|c|c|c|}
\hline $\begin{array}{l}55 \\
55\end{array}$ & $\begin{array}{l}1290 \\
1320\end{array}$ & $\begin{array}{l}3.042 \\
3.051\end{array}$ & $\begin{array}{l}2.726 \\
2.716\end{array}$ & $\begin{array}{l}2.589 \\
2.577\end{array}$ & $\begin{array}{l}76.764 \\
76.766\end{array}$ \\
\hline 55 & 1350 & 3.057 & 2.704 & 2.568 & 76.766 \\
\hline 55 & 1380 & 3.063 & 2.697 & 2.557 & 76.764 \\
\hline 55 & 1410 & 3.063 & 2.688 & 2.551 & 76.766 \\
\hline 55 & 1440 & 3.066 & 2.676 & 2.542 & 76.772 \\
\hline 56 & 30 & 3.066 & 2.665 & 2.531 & 76.777 \\
\hline 56 & 60 & 3.066 & 2.659 & 2.524 & 76.777 \\
\hline 56 & 90 & 3.066 & 2.653 & 2.518 & 76.774 \\
\hline 56 & 120 & 3.066 & 2.647 & 2.509 & 76.764 \\
\hline 56 & 150 & 3.072 & 2.647 & 2.504 & 76.754 \\
\hline 56 & 180 & 3.085 & 2.647 & 2.502 & 76.749 \\
\hline 56 & 210 & 3.130 & 2.647 & 2.493 & 76.746 \\
\hline 56 & 240 & 3.161 & 2.647 & 2.492 & 76.746 \\
\hline 56 & 270 & 3.188 & 2.647 & 2.481 & 76.749 \\
\hline 56 & 300 & 3.219 & 2.647 & 2.480 & 76.754 \\
\hline 56 & 330 & 3.237 & 2.647 & 2.473 & 76.754 \\
\hline 56 & 360 & 3.258 & 2.647 & 2.469 & 76.756 \\
\hline 56 & 390 & 3.274 & 2.647 & 2.469 & 76.756 \\
\hline 56 & 420 & 3.298 & 2.647 & 2.469 & 76.756 \\
\hline 56 & 450 & 3.344 & 2.650 & 2.469 & 76.764 \\
\hline 56 & 480 & 3.389 & 2.656 & 2.461 & 76.794 \\
\hline 56 & 510 & 3.429 & 2.656 & 2.461 & 76.799 \\
\hline 56 & 540 & 3.478 & 2.669 & 2.461 & 76.799 \\
\hline 56 & 570 & 3.517 & 2.675 & 2.461 & 76.797 \\
\hline 56 & 600 & 3.527 & 2.691 & 2.461 & 76.784 \\
\hline 56 & 630 & 3.530 & 2.697 & 2.461 & 76.779 \\
\hline 56 & 660 & 3.536 & 2.704 & 2.461 & 76.766 \\
\hline 56 & 690 & 3.539 & 2.713 & 2.461 & 76.761 \\
\hline 56 & 720 & 3.542 & 2.719 & 2.461 & 76.749 \\
\hline 56 & 750 & 3.539 & 2.728 & 2.464 & 76.733 \\
\hline 56 & 780 & 3.548 & 2.739 & 2.469 & 76.695 \\
\hline 56 & 810 & 3.554 & 2.746 & 2.473 & 76.665 \\
\hline 56 & 840 & 3.560 & 2.761 & 2.483 & 76.639 \\
\hline 56 & 870 & 3.560 & 2.780 & 2.495 & 76.624 \\
\hline 56 & 900 & 3.554 & 2.789 & 2.501 & 76.609 \\
\hline 56 & 930 & 3.554 & 2.795 & 2.507 & 76.591 \\
\hline 56 & 960 & 3.554 & 2.801 & 2.513 & 76.571 \\
\hline 56 & 990 & 3.548 & 2.809 & 2.518 & 76.561 \\
\hline 56 & 1020 & 3.545 & 2.816 & 2.525 & 76.538 \\
\hline 56 & 1050 & 3.542 & 2.816 & 2.528 & 76.530 \\
\hline 56 & 1080 & 3.527 & 2.816 & 2.531 & 76.520 \\
\hline 56 & 1110 & 3.527 & 2.816 & 2.534 & 76.517 \\
\hline 56 & 1140 & 3.527 & 2.816 & 2.536 & 76.520 \\
\hline 56 & 1170 & 3.548 & 2.816 & 2.536 & 76.520 \\
\hline 56 & 1200 & 3.569 & 2.816 & 2.539 & 76.515 \\
\hline 56 & 1230 & 3.591 & 2.816 & 2.542 & 76.505 \\
\hline 56 & 1260 & 3.606 & 2.816 & 2.545 & 76.500 \\
\hline 56 & 1290 & 3.615 & 2.816 & 2.545 & 76.500 \\
\hline 56 & 1320 & 3.627 & 2.816 & 2.547 & 76.505 \\
\hline 56 & 1350 & 3.606 & 2.825 & 2.548 & 76.497 \\
\hline 56 & 1380 & 3.581 & 2.825 & 2.551 & 76.492 \\
\hline 56 & 1410 & 3.566 & 2.825 & 2.551 & 76.487 \\
\hline 56 & 1440 & 3.548 & 2.825 & 2.551 & 76.479 \\
\hline 57 & 30 & 3.536 & 2.825 & 2.551 & 76.479 \\
\hline 57 & 60 & 3.517 & 2.825 & 2.551 & 76.479 \\
\hline 57 & 90 & 3.487 & 2.825 & 2.551 & 76.459 \\
\hline 57 & 120 & 3.469 & 2.819 & 2.551 & 76.439 \\
\hline 57 & 150 & 3.447 & 2.809 & 2.551 & 76.429 \\
\hline 57 & 180 & 3.429 & 2.809 & 2.551 & 76.408 \\
\hline 57 & 210 & 3.423 & 2.809 & 2.551 & 76.401 \\
\hline 57 & 240 & 3.417 & 2.809 & 2.551 & 76.393 \\
\hline 57 & 270 & 3.414 & 2.809 & 2.551 & 76.383 \\
\hline 57 & 300 & 3.414 & 2.809 & 2.551 & 76.368 \\
\hline 57 & 330 & 3.411 & 2.809 & 2.551 & 76.352 \\
\hline 57 & 360 & 3.411 & 2.809 & 2. 551 & 76.350 \\
\hline 57 & 390 & 3.411 & 2.809 & 2.551 & 76.350 \\
\hline 57 & 420 & 3.414 & 2.809 & 2.551 & 76.355 \\
\hline 57 & 450 & 3.432 & 2.803 & 2.551 & 76.355 \\
\hline 57 & 480 & 3.444 & 2.803 & 2.551 & 76.355 \\
\hline 57 & 510 & 3.484 & 2.803 & 2.551 & 76.347 \\
\hline 57 & 540 & 3.508 & 2.803 & 2.551 & 76.327 \\
\hline 57 & 570 & 3.548 & 2.803 & 2.551 & 76.319 \\
\hline 57 & 600 & 3.575 & 2.803 & 2.551 & 76.307 \\
\hline 57 & 630 & 3.606 & 2.803 & 2.551 & 76.297 \\
\hline 57 & 660 & 3.627 & 2.804 & 2.551 & 76.266 \\
\hline 57 & 690 & 3.648 & 2.804 & 2.551 & 76.230 \\
\hline
\end{tabular}




\begin{tabular}{|c|c|c|c|c|c|}
\hline $\begin{array}{l}57 \\
57\end{array}$ & $\begin{array}{l}720 \\
750\end{array}$ & $\begin{array}{l}3.661 \\
3.645\end{array}$ & $\begin{array}{l}2.810 \\
2.822\end{array}$ & $\begin{array}{l}2.551 \\
2.551\end{array}$ & $\begin{array}{l}76.205 \\
76.167\end{array}$ \\
\hline 57 & 780 & 3.636 & 2.822 & 2.557 & 76.131 \\
\hline 57 & 810 & 3.633 & 2.827 & 2.560 & 76.111 \\
\hline 57 & 840 & 3.636 & 2.833 & 2.565 & 76.088 \\
\hline 57 & 870 & 3.645 & 2.841 & 2.566 & 76.068 \\
\hline 57 & 900 & 3.652 & 2.850 & 2.573 & 76.040 \\
\hline 57 & 930 & 3.676 & 2.862 & 2.579 & 76.015 \\
\hline 57 & 960 & 3.691 & 2.874 & 2.583 & 75.997 \\
\hline 57 & 990 & 3.706 & 2.886 & 2.591 & 75.982 \\
\hline 57 & 1020 & 3.728 & 2.899 & 2.597 & 75.954 \\
\hline 57 & 1050 & 3.746 & 2.911 & 2.605 & 75.933 \\
\hline 57 & 1080 & 3.758 & 2.920 & 2.612 & 75.916 \\
\hline 57 & 1110 & 3.770 & 2.929 & 2.620 & 75.898 \\
\hline 57 & 1140 & 3.780 & 2.929 & 2.627 & 75.880 \\
\hline 57 & 1170 & 3.789 & 2.941 & 2.632 & 75.865 \\
\hline 57 & 1200 & 3.795 & 2.944 & 2.638 & 75.847 \\
\hline 57 & 1230 & 3.801 & 2.944 & 2.644 & 75.832 \\
\hline 57 & 1260 & 3.801 & 2.950 & 2.649 & 75.824 \\
\hline 57 & 1290 & 3.801 & 2.950 & 2.652 & 75.819 \\
\hline 57 & 1320 & 3.801 & 2.950 & 2.655 & 75.804 \\
\hline 57 & 1350 & 3.801 & 2.950 & 2.659 & 75.794 \\
\hline 57 & 1380 & 3.801 & 2.960 & 2.661 & 75.789 \\
\hline 57 & 1410 & 3.798 & 2.960 & 2.664 & 75.786 \\
\hline 57 & 1440 & 3.798 & 2.960 & 2.665 & 75.783 \\
\hline 58 & 30 & 3.764 & 2.960 & 2.667 & 75.783 \\
\hline 58 & 60 & 3.746 & 2.960 & 2.670 & 75.773 \\
\hline 58 & 90 & 3.719 & 2.960 & 2.670 & 75.740 \\
\hline 58 & 120 & 3.694 & 2.960 & 2.672 & 75.715 \\
\hline 58 & 150 & 3.682 & 2.960 & 2.672 & 75.695 \\
\hline 58 & 180 & 3.676 & 2.960 & 2.672 & 75.672 \\
\hline 58 & 210 & 3.673 & 2.960 & 2.672 & 75.662 \\
\hline 58 & 240 & 3.676 & 2.960 & 2.672 & 75.649 \\
\hline 58 & 270 & 3.688 & 2.960 & 2.672 & 75.644 \\
\hline 58 & 300 & 3.703 & 2.960 & 2.672 & 75.618 \\
\hline 58 & 330 & 3.719 & 2.960 & 2.673 & 75.603 \\
\hline 58 & 360 & 3.734 & 2.960 & 2.676 & 75.603 \\
\hline 58 & 390 & 3.755 & 2.963 & 2.679 & 75.590 \\
\hline 58 & 420 & 3.789 & 2.972 & 2.685 & 75.580 \\
\hline 58 & 450 & 3.828 & 2.975 & 2.684 & 75.575 \\
\hline 58 & 480 & 3.868 & 2.981 & 2.690 & 75.562 \\
\hline 58 & 510 & 3.898 & 2.993 & 2.693 & 75.555 \\
\hline 58 & 540 & 3.935 & 3.002 & 2.699 & 75.512 \\
\hline 58 & 570 & 3.947 & 3.008 & 2.710 & 75.466 \\
\hline 58 & 600 & 3.953 & 3.021 & 2.716 & 75.446 \\
\hline 58 & 630 & 3.938 & 3.030 & 2.722 & 75.438 \\
\hline 58 & 660 & 3.935 & 3.030 & 2.733 & 75.420 \\
\hline 58 & 690 & 3.929 & 3.030 & 2.736 & 75.410 \\
\hline 58 & 720 & 3.920 & 3.030 & 2.740 & 75.382 \\
\hline 58 & 750 & 3.901 & 3.036 & 2.745 & 75.331 \\
\hline 58 & 780 & 3.886 & 3.036 & 2.749 & 75.275 \\
\hline 58 & 810 & 3.853 & 3.036 & 2.754 & 75.232 \\
\hline 58 & 840 & 3.822 & 3.036 & 2.760 & 75.184 \\
\hline 58 & 870 & 3.792 & 3.036 & 2.768 & 75.176 \\
\hline 58 & 900 & 3.770 & 3.036 & 2.768 & 75.138 \\
\hline 58 & 930 & 3.740 & 3.036 & 2.768 & 75.098 \\
\hline 58 & 960 & 3.725 & 3.036 & 2.771 & 75.057 \\
\hline 58 & 990 & 3.712 & 3.045 & 2.774 & 75.021 \\
\hline 58 & 1020 & 3.706 & 3.045 & 2.780 & 74.981 \\
\hline 58 & 1050 & 3.700 & 3.060 & 2.783 & 74.960 \\
\hline 58 & 1080 & 3.697 & 3.060 & 2.786 & 74.948 \\
\hline 58 & 1110 & 3.688 & 3.060 & 2.786 & 74.938 \\
\hline 58 & 1140 & 3.685 & 3.060 & 2.786 & 74.905 \\
\hline 58 & 1170 & 3.682 & 3.060 & 2.789 & 74.882 \\
\hline 58 & 1200 & 3.673 & 3.060 & 2.789 & 74.869 \\
\hline 58 & 1230 & 3.661 & 3.060 & 2.789 & 74.859 \\
\hline 58 & 1260 & 3.648 & 3.060 & 2.789 & 74.833 \\
\hline 58 & 1290 & 3.645 & 3.054 & 2.789 & 74.813 \\
\hline 58 & 1320 & 3.636 & 3.048 & 2.789 & 74.808 \\
\hline 58 & 1350 & 3.615 & 3.039 & 2.789 & 74.788 \\
\hline 58 & 1380 & 3.600 & 3.033 & 2.786 & 74.752 \\
\hline 58 & 1410 & 3.578 & 3.024 & 2.786 & 74.699 \\
\hline 58 & 1440 & 3.554 & 3.021 & 2.786 & 74.676 \\
\hline 59 & 30 & 3.539 & 3.005 & 2.786 & 74.651 \\
\hline 59 & 60 & 3.517 & 2.993 & 2.783 & 74.633 \\
\hline 59 & 90 & 3.505 & 2.987 & 2.780 & 74.592 \\
\hline 59 & 120 & 3.490 & 2.978 & 2.774 & 74.544 \\
\hline
\end{tabular}




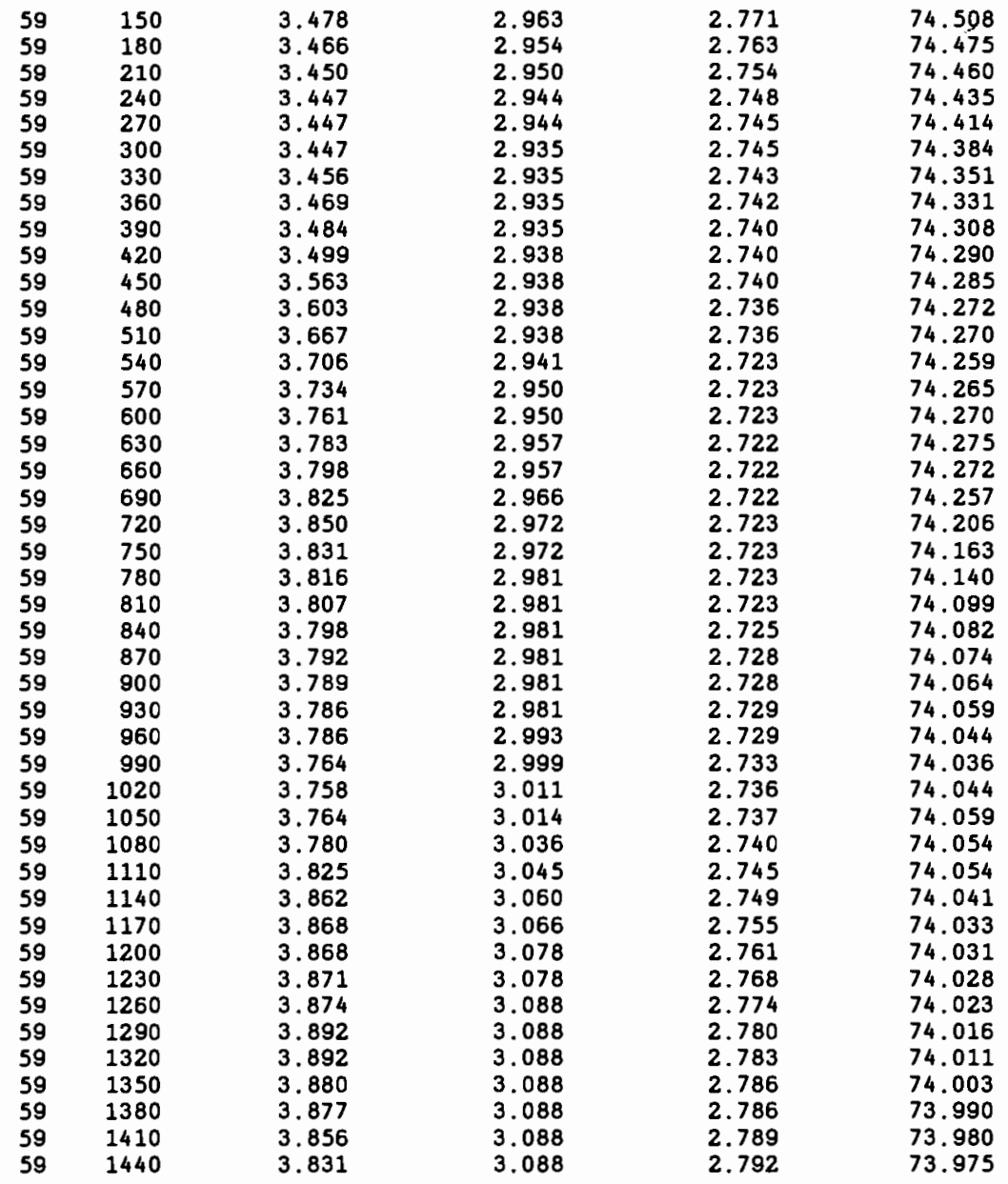


PRECIPITATION FOR FEBRUARY 1991

(RECORDED AT PORTLAND INTERNATIONAL AIRPORT)

$\begin{array}{cc}\begin{array}{c}\text { JULIAN } \\ \text { DAY }\end{array} & \begin{array}{c}\text { PRECIPITATION } \\ \text { (CENTIMETERS) }\end{array} \\ 32 & 0.56 \\ 33 & 0.84 \\ 34 & 0.66 \\ 35 & 0.81 \\ 36 & 0.81 \\ 37 & 0.00 \\ 38 & 0.00 \\ 39 & 0.00 \\ 40 & 0.00 \\ 41 & 0.00 \\ 42 & 0.00 \\ 43 & 0.89 \\ 44 & 0.94 \\ 45 & 0.61 \\ 46 & 0.00 \\ 47 & 0.36 \\ 48 & 0.00 \\ 49 & 0.00 \\ 50 & 0.23 \\ 51 & 1.63 \\ 52 & 1.50 \\ 53 & 0.00 \\ 54 & 0.00 \\ 55 & 0.00 \\ 56 & 0.00 \\ 57 & 0.00 \\ 58 & 0.00 \\ 59 & 0.00 \\ & \end{array}$


APPENDIX C

COMPUTER PROGRAMS 
C PROGRAM 5.9 DAVIS PG 249 BY AG JOHNSON $1 / 28 / 86$ VERSION 1.1

C

$3 / 20 / 86$

ADDED PRINT OPTIONS

C MODIFIED $7 / 12 / 91$ BY JM WILKINSON

C PRINT OPTION REMOVED

C ADDED ABS() TO SQRT FUNCTIONS

$C \quad$ INCREASED FILE SIZES

C OUTPUT TO DISK FILES

C

C ROUTINE CROSCR

C

C PROGRAM TO PERFORM CROSSCORRELATION BETWEEN TWO SEQUENCES OF DATA

C

C XIN1 CONTAINS THE FIRST DATA SEQUENCE OF NIN1 ELEMENTS

C XIN2 IS THE SECOND DATA SEQUENCE OF LENGTH NIN2

C THE CORRELATION COEFFICIENTS CALCULATED AT EACH MATCH POSITION ARE

C

C STORED IN ARRAY XOUT. THE NUMBER OF CORRELATION COEFFICIENTS IN

C XOUT IS NOT $=$ NIN1 + NIN2 - 5 .

C

C IBI $=$ FIRST TERM OF XIN1 IN THE OVERLAPPED SEGMENT

C IE1 = LAST TERM OF XIN1 IN THE OVERLAPPED SEGMENT

C $\quad$ IB2 $=$ FIRST TERM OF XIN2 IN THE OVERLAPPED SEGMENT

C IE2 = LAST TERM OF XIN2 IN THE OVERLAPPED SEGMENT

C LEN1 = NUMBER OF TERMS OF XIN1 IN THE OVERLAPPED SEGMENT

C LEN2 = NUMBER OF TERMS OF XIN2 IN THE OVERLAPPED SEGMENT

C

C THE SUBROUTINES REQUIRED ARE READM

C THE MAXIMUM LENGTH OF EACH INPUT DATA SEQUENCE IS 2000 ELEMENTS.

C

DIMENSION XIN1 (2000),XIN2(2000), XOUT (4000)

CHARACTER* 1 RESPONS

CHARACTER * 14 FILENAME, TIM, DAT, DATOUT, MATOUT

$\operatorname{IMX}=2000$

C

C READ IN THE TWO DATA SEQUENCES TO BE CROSSCORRELATED WRITE $(*, *)$ ' INPUT THE DATE eg $10 / 5 / 90$ ' 
READ $(*, 910)$ DAT

WRITE $(*, *)$ ' INPUT THE TIME eg 10:21 PST'

READ $(*, 910)$ TIM

206 WRITE $(*, 900)$

900 FORMAT (' INPUT DATA FILE NAME - eg A:CROSCR.DAT ')

READ (*,910) FILENAME

WRITE $(*, 903)$

903 FORMAT (' INPUT NAME OF OUTPUT FILE eg. A:DAT.OUT')

READ $(*, 910)$ DATOUT

WRITE $(*, 906)$

906 FORMAT (' INPUT NAME OF MATCH OUTPUT FILE eg. A:MATCH.MAT')

READ $(*, 910)$ MATOUT

910 FORMAT (A)

OPEN (5, FILE=FILENAME)

OPEN ( 7, FILE=DATOUT, STATUS= 'NEW' $)$

OPEN $(8$, FILE=MATOUT, STATUS $=$ ' NEW' $)$

WRITE $(8,920)$ FILENAME, DAT, TIM

920 FORMAT (1HO,' PROGRAM CROSCR DAVIS PG 249 VERSION $1.13 / 20 / 86^{\prime}$,

$1 /$, DATA FILE $=1$, A14,' DATE ',A14,' TIME ',A14,/)

CALL READM (XIN1, NIN1, MN, IMX, 1)

200 FORMAT (AI)

201 CALL READM(XIN2, NIN2, MN, IMX, 1)

202 WRITE $(8,2000)$

NOT $=$ NIN $1+N I N 2-5$

$I B I=1$

$I E 1=3$

IB $2=N I N 2-2$

IE $2=\mathrm{N} I \mathrm{~N} 2$

LEN $1=3$

DO $100 \mathrm{I}=1$, NOT

$\mathrm{SX}=0.0$

$S Y=0.0$

$S X Y=0.0$

$\mathrm{SXX}=0.0$

$S Y Y=0.0$

DO $101 \mathrm{~J}=1$, LEN 1

$J I=I B I+J-I$

$\mathrm{J} 2=\mathrm{IB} 2+\mathrm{J}-1$

$\mathrm{X} 1=\mathrm{XIN} 1(\mathrm{~J} 1)$

$\mathrm{X} 2=\mathrm{XIN} 2(\mathrm{~J} 2)$

$\mathrm{SX}=\mathrm{SX}+\mathrm{XI}$

$S Y=S Y+X 2$

$S X Y=S X Y+X 1 * X 2$

$\mathrm{SXX}=\mathrm{SXX}+\mathrm{X} 1 * \mathrm{XI}$

$S Y Y=S Y Y+X 2 * X 2$ 
101 CONTINUE

AN $=$ LEN 1

$R=(A N * S X Y-S X * S Y) / S Q R T(A B S((A N * S X X-S X * S X) *(A N * S Y Y-S Y * S Y)))$

$\mathrm{T}=\mathrm{R} * \mathrm{SQRT}(\operatorname{ABS}((\mathrm{AN}-2.0) /(1.0-\mathrm{R} * \mathrm{R})))$

XOUT (I) $=R$

WRITE $(8,2001)$ I, IB1, IE1, IB2, IE2, LEN1, R, T

$I E 1=I E 1+1$

IF (IE1-NIN1) $2,2,1$

$1 \mathrm{IBI}=\mathrm{IBI}+1$

$I E I=N I N 1$

2 IB2 $=I B 2-1$

IF (IB2) $3,3,4$

$3 \quad \mathrm{IB2}=1$

$I E 2=I E 2-1$

4 LENI $=$ IEI $1-I B 1+1$

$\mathrm{LEN} 2=\mathrm{IE} 2-\mathrm{IB} 2+1$

IF (LEN1-LEN2) 5,100,6

5 IBI $=1$

$I E 2=I E 2-1$

GO TO 4

$6 \mathrm{IBI}=\mathrm{IBI}+1$

$I E 2=N I N 2$

GO TO 4

100 CONTINUE

DO $199 \mathrm{I}=1$, NOT

WRITE $(7,198) \quad I, \operatorname{XOUT}(I)$

199 CONTINUE

198 FORMAT $(1 X, I 4, ', ', F 10.4)$

205 WRITE $(*, *)$ ' DO YOU WANT TO DO ANOTHER DATA SET? '

WRITE $(*, *)$ ' IF YES, TYPE Y, IF NOT RETURN '

READ ( *,200) RESPONS

IF (RESPONS .EQ. ' $Y$ ') THEN

CLOSE (5, STATUS $=$ ' KEEP')

CLOSE ( 7, STATUS $=$ 'KEEP')

CLOSE ( 8, STATUS $=$ ' KEEP')

ENDIF

GO TO 206

STOP

2000 FORMAT (1H1, $14 \mathrm{X}$, 'TERMS WHICH ARE MATCHED', 7X, 'NUMBER'/

14X, 'MATCH' ', $8 \mathrm{X}$, ' FIRST' , 9X, 'SECOND' , 6X, ' OF TERMS ',

23X, ' CORRELATION' , 7X, 'T'/3X, 'POSITION' , 4X, 'DATA

$\mathrm{SET}^{\prime}, 6 \mathrm{X}$,

$32 \mathrm{X}$, 'DATA

SET' , 6X, 'MATCHED' , 2X, 'COEFFICIENT' , 5X, 'VALUE'/) 


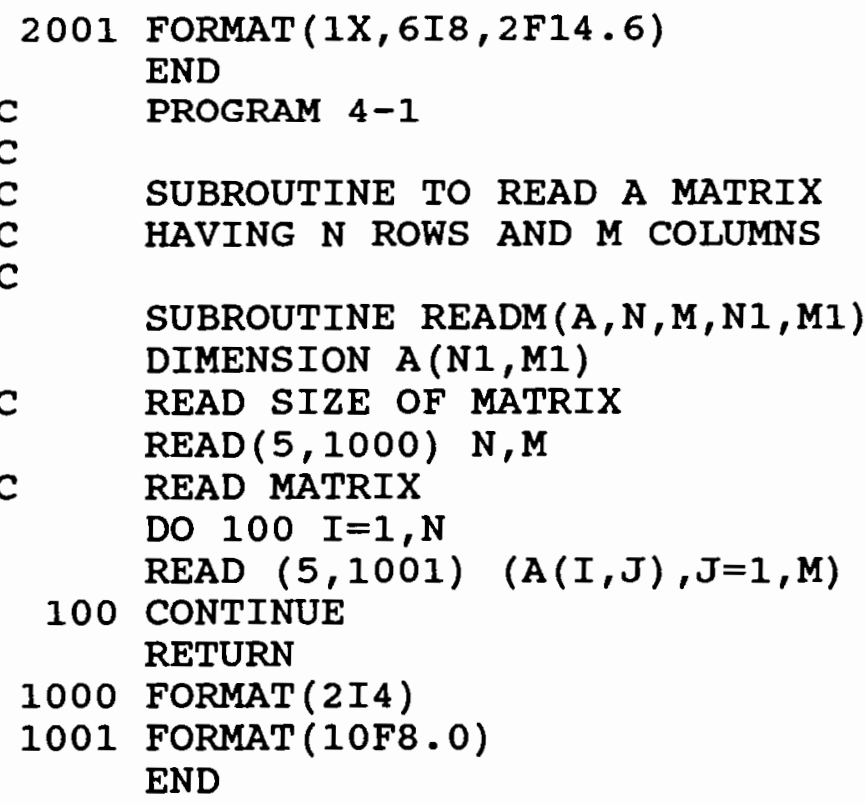

